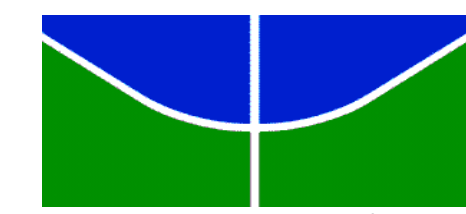

UNIVERSIDADE DE BRASÍLIA - UnB

FACULDADE DE CIÊNCIA DA INFORMAÇÃO

PROGRAMA DE PÓS-GRADUAÇÃO EM CIÊNCIA DA INFORMAÇÃO - (PPGCInf)

CECÍLIA MORENA MARIA DA SILVA

PERFIL E COMPETÊNCIAS DOS BIBLIOTECÁRIOS QUE ATUAM NA REDE FEDERAL DE ENSINO PROFISSIONAL E TECNOLÓGICO DO DISTRITO FEDERAL

BRASÍLIA

2015 
Universidade de Brasília (UnB)

Faculdade de Ciência da Informação ( $\mathrm{FCl}$ )

Programa de Pós-Graduação em Ciência da Informação (PPGCInf)

CECÍLIA MORENA MARIA DA SILVA

\section{PERFIL E COMPETÊNCIAS DOS BIBLIOTECÁRIOS QUE ATUAM NA REDE FEDERAL DE ENSINO PROFISSIONAL E TECNOLÓGICO DO DISTRITO FEDERAL}

Dissertação de Mestrado, apresentada ao Programa de Pós-Graduação em Ciência da Informação da Faculdade de Ciência da Informação - Universidade de Brasília, como requisito parcial para a obtenção do Título de Mestre em Ciência da Informação.

Linha de Pesquisa: Comunicação e Mediação da Informação.

Grupo de Pesquisa: Profissional da Informação.

Orientador: Profa. Dr ${ }^{a}$. Sofia Galvão Baptista

Co-orientador: $\mathrm{Dr}^{\mathrm{a}}$ Maria Tereza Machado Teles Walter

BRASÍLIA, DF 


\section{FICHA CATALOGRÁFICA}

S586p Silva, Cecília Morena Maria da.

Perfil e competências dos bibliotecários que atuam na Rede Federal de Ensino Profissional e Tecnológico do Distrito Federal [manuscrito] / Cecília Morena Maria da Silva. - 2015.

$124 \mathrm{f}$.

Dissertação (mestrado) - Universidade de Brasília, Faculdade de Ciência da Informação, 2015.

1. Competências Profissionais. 2. Perfil Profissional. 3. Profissional da Informação. 4. Bibliotecários. 5. Instituto Federal de Educação Profissional e Tecnológica. 6. Informação Tecnológica. 


\section{FOLHA DE APROVAÇÃO}

Título: "Perfil e competências dos bibliotecários que atuam na Rede Federal de Educação Profissional e Tecnológica do Distrito Federal".

Autor (a): Cecília Morena Maria da Silva

Área de concentração: Gestão da Informação

Linha de pesquisa: Comunicação e Mediação da Informação

Dissertação submetida à Comissão Examinadora designada pelo Colegiado do Programa de Pósgraduação em Ciência da Informação da Faculdade em Ciência da Informação da Universidade de Brasília como requisito parcial para obtenção do título de Mestre em Ciência da Informação.

Brasília, 10 de agosto de 2015.

mantem z. nito Wallt

Profa. Dra. Maria Tereza Machado Teles Walter

Presidente (STF)

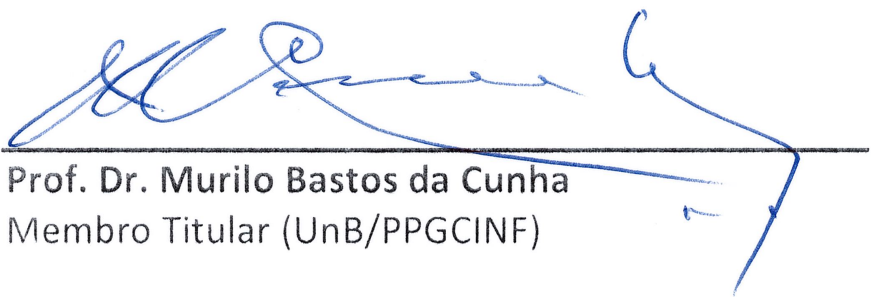

$\frac{\text { Waria de fatmi Gabelmi }}{\text { Profa. Dra. Maria de Fátima Garbelini }}$

Membro Titular (UFG)

Prof. Dr. Fernando César Lima Leite

Membro Suplente (UnB/PPGCINF) 


\section{AGRADECIMENTOS}

A Deus, por me dar vida, saúde, inteligência e disposição para lutar por meus objetivos;

À minha querida mãe, por ser meu porto seguro e estar sempre pronta a me ajudar, a qualquer hora e em qualquer situação;

À minha família, por sempre me acolher e me apoiar em minhas empreitadas;

Aos meus amigos, em especial: Thalita Santos que me auxiliou muito, para a concretização dessa dissertação; Mirian Alves, pela amizade que se iniciou na graduação e foi imensamente reforçada na pós-graduação; Ana Carolina Cintra Faria pelo apoio nas horas de angústia e troca de experiências e Sônia Boeres, pelas dicas e ajudas valiosas que forneceu durante minha jornada no curso de mestrado;

À professora Dra. Sofia Galvão, pela orientação e por compartilhar comigo, de maneira tão brilhante, seu conhecimento;

À Dra. Maria Tereza Walter, por ter aceitado a co-orientação da minha pesquisa no momento em que mais precisei e por me ajudar, de maneira muito profissional e criteriosa, na finalização desta dissertação;

Aos professores doutores Murilo Bastos da Cunha e Maria de Fátima Garbelini, por aceitarem, prontamente, participar da banca examinadora tanto da qualificação, quanto da defesa da minha dissertação e pelas valiosas contribuições, que enriqueceram sobremaneira o meu trabalho;

Ao professor Dr. Fernando Leite, por ter aceitado a suplência na banca examinadora deste trabalho;

Aos bibliotecários do Instituto Federal de Educação, Ciência e Tecnologia de Goiás, por terem colaborado com a minha pesquisa durante a aplicação do pré-teste do instrumento de coleta de dados;

Aos bibliotecários do Instituto Federal de Educação, Ciência e Tecnologia de Brasília, em especial à Camila Cândido, Marcelo Conceição e Elisa Raquel, por aceitarem participar da minha pesquisa, fornecendo informações de grande valia, sem as quais não seria possível a realização desse trabalho;

Aos servidores da secretaria da pós-graduação em Ciência da Informação da UnB, por serem tão prestativos no atendimento;

E por fim, ao Programa de Pós-Graduação em Ciência da Informação da UnB, por me proporcionar a oportunidade de cursar, com qualidade, a pósgraduação em uma instituição internacionalmente conceituada. 


\section{RESUMO}

O estudo pretendeu mapear as competências profissionais necessárias ao desempenho das atividades dos bibliotecários que atuam na rede federal de ensino profissional e tecnológico do Distrito Federal, a partir da percepção desses profissionais. Para atingir o objetivo proposto, adotou-se uma base teórica voltada à contextualização das abordagens contemporâneas sobre a noção de competência e mapeamento de competências e um estudo da literatura na área de Biblioteconomia e Ciência da Informação sobre perfil e competências do bibliotecário. Metodologicamente, trata-se de um estudo de caso, de abordagem descritiva e caráter quanti-qualitativo. As informações foram coletadas por meio de um questionário semiestruturado, composto de perguntas abertas e fechadas e de um roteiro de entrevista, realizado após a aplicação do questionário. Para a elaboração dos instrumentos de coleta de dados foram realizadas pesquisas bibliográficas e documentais, no intuito de levantar as variáveis aplicáveis aos objetivos propostos. Por meio da aplicação do questionário e posterior entrevista com os bibliotecários, aliado à pesquisa documental, obteve-se o diagnóstico que permitiu mapear as competências e o perfil dos bibliotecários. Em relação ao perfil, foi possível reconhecer, dentre outros fatores, uma população jovem de profissionais atuando na Rede, sendo a maioria do sexo feminino e detentora de formação acadêmica complementar. $O$ mapeamento das competências possibilitou detectar maiores aptidões relacionadas às competências em comunicação e expressão e competências gerenciais dos bibliotecários. Por fim, concluiu-se que as competências mapeadas estão de acordo com os objetivos institucionais da rede federal de ensino profissional e tecnológico do Distrito Federal.

Palavras-chave: Competências Profissionais. Perfil Profissional. Profissional da Informação. Informação Tecnológica. Bibliotecário. Instituto Federal de Educação Profissional e Tecnológica. 


\begin{abstract}
The study had the objective of characterize the professional skills required for the activities of librarians working in the federal network of technical and technological education of the Federal District (Brazil), in perception of these professionals. To achieve the objective, it was adopted a contemporary theory of competence and competency mapping and literature review in Library and Information Science on profile and skills of librarian. This is a case study, quanti-qualitative research with descriptive approach. The information was collected through a semi-structured questionnaire composed of open and closed questions and an interview script, performed after the questionnaire. To elaborate the data collection instrument were carried out bibliographic and documentary research in order to raise the variables applied to the proposed objectives. Through the questionnaire and subsequent treatment of the information collected, together with documentary research, it was obtained the diagnosis that identified the profile and characterized the skills of librarians. Regarding the profile, it was possible to recognize, among other factors, a young population of professionals working in the network, mostly female that had additional academic training. The mapping of competencies enabled to detect higher professional skills related to communication and expression skills and managerial skills of librarians. Finally, it was concluded that mapped competencies are in accordance with the institutional objectives in the federal network of technical and technological education of the Federal District.
\end{abstract}

Keywords: Professional Competencies. Professional Profile. Information Professional. Librarian. Technological Information. Federal Network of Technical and Technological Education. 


\section{LISTA DE FIGURAS}

Figura 1 - Articulação entre competências essenciais, de grupos e 23 individuais

Figura 2 - Modelo baseado em competências 25

Figura 3 - Abordagem para mapeamento da estrutura de cargos 37

Figura 4 - Abordagem tradicional geral 44

$\begin{array}{lll}\text { Figura } 5 \text { - Abordagem sistêmica } & 44\end{array}$ 


\section{LISTA DE QUADROS}

Quadro 1 - Atributos de competência 22

Quadro 2 - Desenvolvimento de competências nas organizações 24

Quadro 3 - Competências sugeridas por alguns palestrantes no XXVI 31 ENEBD

Quadro 4 - Competências desejáveis e exigíveis a um profissional egresso 32 de uma universidade na área de Biblioteconomia/Ciência da Informação no Mercosul

Quadro 5 - $\quad$ Passos para realização do mapeamento 38

Quadro 6 - Modelo para o mapeamento de competências em inteligência 40 competitiva

Quadro 7 - Comparativo entre a empresa da sociedade industrial e a 45 empresa da sociedade da informação

Quadro 8 - $\quad$ Comparação entre os perfis e as atitudes dos tradicionais e dos 50 modernos profissionais da informação

Quadro 9 - $\quad$ Competências mapeadas $\quad 95$

Quadro 10 - Comparativo entre as competências dos bibliotecários e as 97 estratégias, planos e atribuições do IFB

Quadro 11 - Perfil dos bibliotecários que atuam no IFB 


\section{LISTA DE TABELAS}

Tabela 1 - Tempo de atuação do bibliotecário no IFB $\quad$ Te 69

Tabela 2 - Tempo de formado em Biblioteconomia 69

Tabela 3 - $\quad$ Tempo de atuação como bibliotecário 70

$\begin{array}{lll}\text { Tabela } 4 \text { - Faixa etária } & 71\end{array}$

Tabela 5 - Sexo $\quad 72$

Tabela 6 - Formação complementar 73

$\begin{array}{lll}\text { Tabela } 7 \text { - } \quad \text { Conhecimento em idiomas } & 74\end{array}$

$\begin{array}{lll}\text { Tabela } 8 \text { - } \quad \text { Faixa salarial } & 75\end{array}$

Tabela 9 - Função do bibliotecário na instituição 76

Tabela 10 - Cursos de capacitação 78

Tabela 11 - Características que o bibliotecário deve possuir para atuar 79 no IFB

Tabela 12 - Relevância dos cursos de capacitação para o exercício 81 profissional do bibliotecário que atua no IFB

Tabela 13 - Itens que influenciaram o bibliotecário na decisão de 84 trabalhar no IFB

Tabela 14 - Competências em comunicação e expressão 86

Tabela 15 - Competências técnico-científicas 88

Tabela 16 - Competências gerenciais 90

Tabela 17 - Competências sociais e políticas 92 


\section{LISTA DE SIGLAS}

CEFETS

$\mathrm{CHA}$

DSC

ENEBD

ENANCIB

FID

GC

GDF

IFB

MIP

PDE

PDI

SIBIFB

SNBU

SWOT

TIC

USP
Centros Federais de Educação Tecnológica

Competências, Habilidades e Atitudes

Discurso do Sujeito Coletivo

Encontro Nacional dos Estudantes de Biblioteconomia, Documentação, Ciência e Gestão da Informação

Encontro Nacional de Pesquisa em Ciência da Informação

Federação Internacional de Informação e Documentação

Gestão por Competências

Governo do Distrito Federal

Instituto Federal de Educação, Ciência e Tecnologia de Brasília

Moderno Profissional da Informação

Plano de Desenvolvimento da Educação

Plano de Desenvolvimento Institucional

Sistema de Bibliotecas do Instituto Federal de Educação, Ciência e Tecnologia de Brasília

Seminário Nacional de Bibliotecas Universitárias

Strengths, Weaknesses, Opportunities and Threats

Tecnologia da Informação e Comunicação

Universidade de São Paulo 


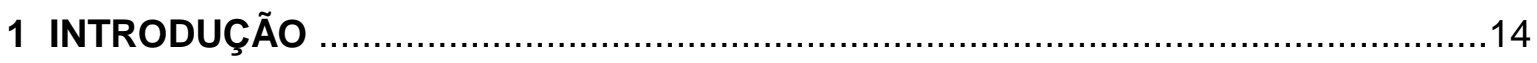

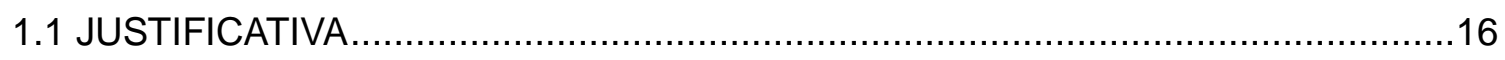

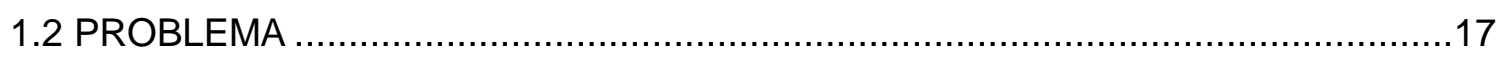

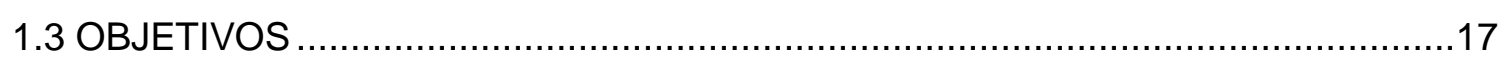

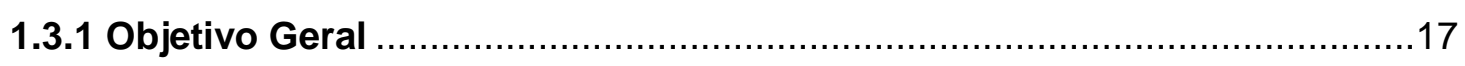

1.3.2 Objetivos Específicos.......................................................................

2 REVISÃO DE LITERATURA - COMPETÊNCIA E PERFIL PROFISSIONAL …...........18

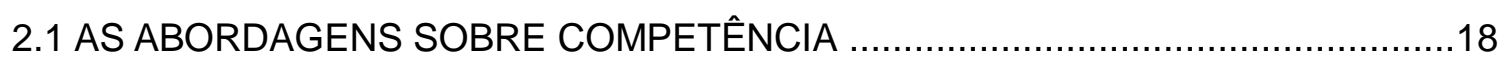

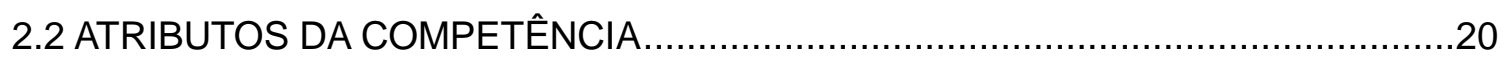

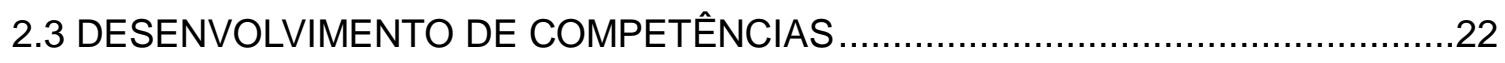

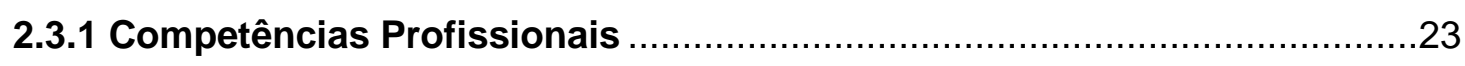

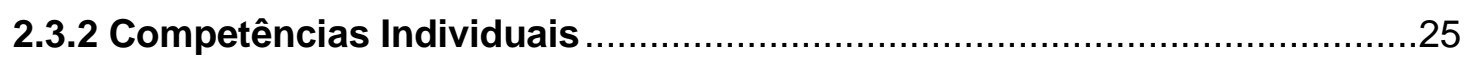

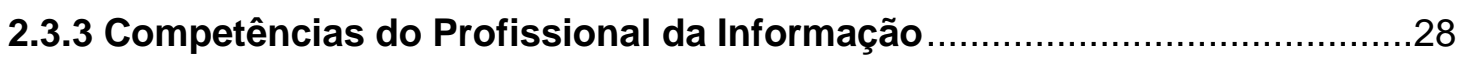

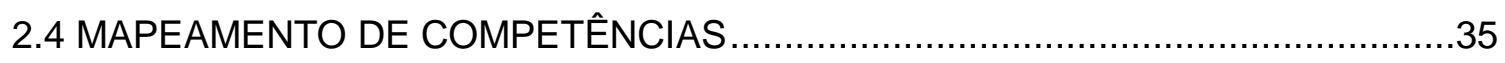

2.4.1 Mapeamento de Competências em Unidades de Informação.......................38

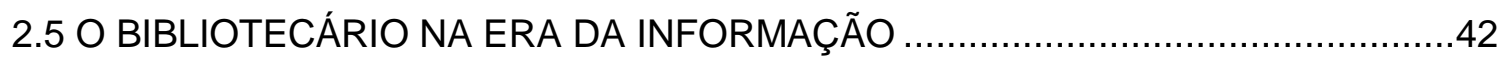

2.5.1 Caracterização da Sociedade da Informação.............................................42

2.5.2 O Perfil do Bibliotecário na Sociedade da Informação ...............................45

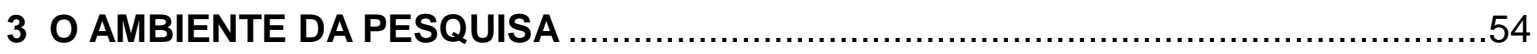

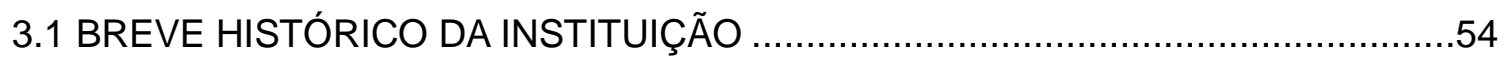

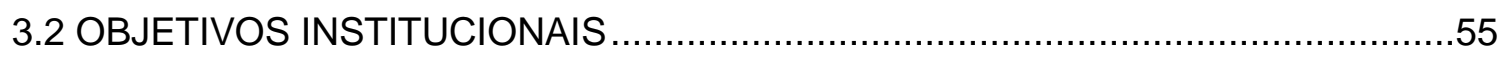

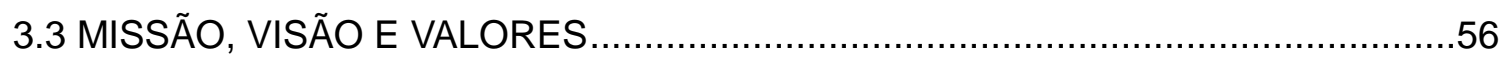

3.4 O SISTEMA DE BIBLIOTECAS DO INSTITUTO FEDERAL DE EDUCAÇÃO,

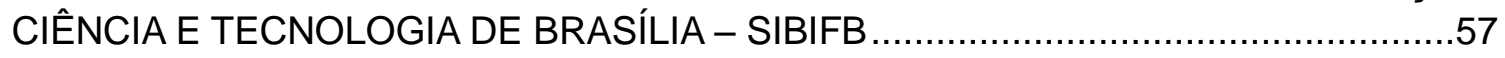

3.4.1 Atribuições das Coordenações de Biblioteca do IFB...............................57

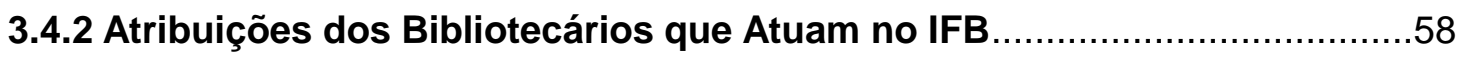

3.4.3 Serviços Oferecidos pelo Sistema de Bibliotecas - SIBIFB .....................60

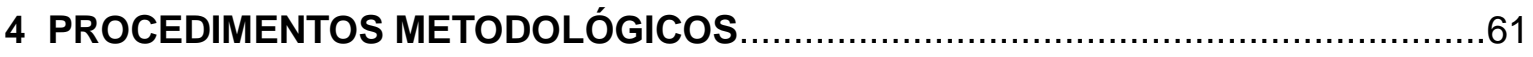

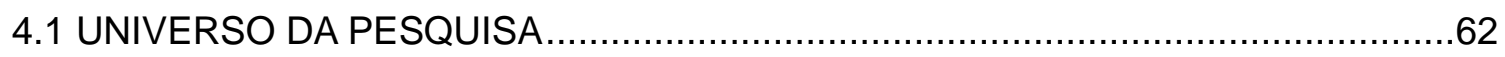

4.2 COLETA DE DADOS

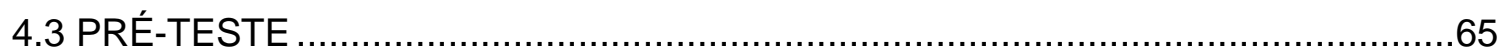

5 ANÁLISE DOS DADOS COLETADOS

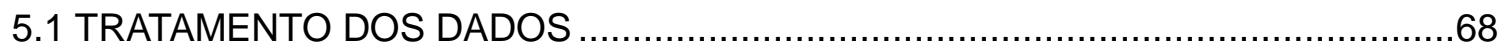


5.2 APRESENTAÇÃO E ANÁLISE DOS RESULTADOS .68

5.2.1 Perfil dos Bibliotecários .68

5.2.2 Competências Mapeadas .85

6 CONCLUSÕES DO ESTUDO .94

6.1 MAPEAMENTO DAS COMPETÊNCIAS DOS BIBLIOTECÁRIOS DO IFB. .94

6.2 VERIFICAÇÃO DA CONFORMIDADE DAS COMPETÊNCIAS MAPEADAS .97

6.3 IDENTIFICAÇÃO DO PERFIL DOS BIBLIOTECÁRIOS QUE ATUAM NO IFB ....101

6.4 CONSIDERAÇÕES FINAIS E SUGESTÕES DE PESQUISAS FUTURAS ... 104 REFERÊNCIAS 107

APÊNDICE 1 - QUESTIONÁRIO: PERFIL E COMPETÊNCIAS DOS BIBLIOTECÁRIOS QUE ATUAM NA REDE FEDERAL DE ENSINO DO DISTRITO FEDERAL 


\section{INTRODUÇÃO}

Na última década do século XX, o Brasil tem presenciado uma série de transformações em seu cenário político, social e econômico. Isso se deve, em grande parte, aos significativos avanços ocorridos em termos de produção de informação e geração de conhecimento.

Nesse contexto de transformação da sociedade por intermédio da informação e do conhecimento é que se inserem os Institutos de Educação Profissional e Tecnológica brasileiros, que têm por função oferecer cursos de qualificação, técnicos, superiores de tecnologia, licenciaturas e programas de pósgraduação lato e stricto sensu, que estão regulamentados pela Lei oㅜ 11.892, de 29 de dezembro de 2008. São os ambientes onde a essência do conhecimento técnico e científico é produzida e que, devido a essas constantes transformações, devem traçar uma estrutura de ensino que transcenda à mera transmissão de informações.

Em se tratando de instituições de ensino público, em especial as federais, essa relação "ensino versus transformação da sociedade", torna-se ainda mais marcante. De acordo com Chaui (2003, p. 5):

[...] Essa relação interna ou expressiva entre universidade e sociedade é o que explica, aliás, o fato de que, desde seu surgimento, a universidade pública sempre foi uma instituição social, isto é, uma ação social, uma prática social fundada no reconhecimento público de sua legitimidade e de suas atribuições, num princípio de diferenciação, que the confere autonomia perante outras instituições sociais, e estruturada por ordenamentos, regras, normas e valores de reconhecimento e legitimidade internos a ela.

No tocante aos Institutos Federais de Educação, Ciência e Tecnologia essa relação não é diferente. Em 2008, um novo modelo de instituição educacional em nível Federal, estruturado a partir do potencial existente nos antigos Centros Federais de Educação Tecnológica (Cefets), Escolas Técnicas Federais, Agrotécnicas e algumas vinculadas às Universidades Federais, os novos Institutos Federais foram criados com a intenção de que o Brasil alcançasse condições estruturais necessárias ao desenvolvimento educacional e socioeconômico (BRASIL. MINISTÉRIO DA EDUCAÇÃO, 2014b). 
Os Institutos Federais têm como missão responder, de forma ágil e eficaz, às crescentes demandas por formação profissional, por difusão de conhecimentos científicos e tecnológicos e de suporte aos arranjos produtivos locais. Atuam em todos os níveis e modalidades da educação profissional, com foco no desenvolvimento integral do cidadão trabalhador e articulam os princípios formuladores do Plano de Desenvolvimento da Educação (PDE) (BRASIL. MINISTÉRIO DA EDUCAÇÃO, 2014b).

Esse novo modelo educacional, aliado às universidades públicas, tem aberto perspectivas para o ensino médio e superior, por meio da combinação do ensino de ciências naturais, humanidades e educação profissional e tecnológica.

A região Centro-Oeste possui, em 2015, cinco Universidades e cinco Institutos de Educação, Ciência e Tecnologia em sua rede federal de ensino. No Distrito Federal, encontram-se o Instituto Federal de Educação, Ciência e Tecnologia de Brasília (IFB), com dez campi em funcionamento e a Universidade de Brasília, com quatro campi. A rede está em fase de expansão e prevê-se aumento do número de campi nessas instituições, em 2015 (BRASIL. MINISTÉRIO DA EDUCAÇÃO, 2014b).

Neste contexto de transferência da informação e produção de conhecimento, encontram-se as bibliotecas da rede federal de educação profissional e tecnológica. Para esta pesquisa foram estudadas aquelas pertencentes à rede do Distrito Federal e os bibliotecários que nelas atuam.

No ambiente acadêmico, as bibliotecas desenvolvem o papel de atender, principalmente, às necessidades específicas de ensino, pesquisa e extensão da comunidade inerente a esse contexto. Fornecem os mais variados tipos de informação, em diferentes campos do saber científico, o que requer do profissional que atua nesse tipo de biblioteca a posse de certas características pessoais, além de competências gerais e específicas que estejam diretamente relacionadas a esse segmento educacional, para que desenvolva suas funções de maneira eficiente.

A presente pesquisa foi dividida em oito capítulos, onde o primeiro, de caráter introdutório, apresenta a justificativa do estudo e os objetivos que se 
pretendem alcançar. O segundo capítulo foi destinado à revisão de literatura sobre as abordagens, atributos, desenvolvimento e mapeamento de competências e aborda, ainda, sobre o perfil do bibliotecário na era da informação. $O$ terceiro capítulo retrata $O$ ambiente em que a pesquisa foi desenvolvida, discorrendo sobre um breve histórico da instituição, seus objetivos, missão, visão, valores e atribuições. O quarto e quinto capítulos tratam dos procedimentos metodológicos e análise dos dados coletados. O sexto capítulo traz as conclusões obtidas no estudo, detalhando o perfil e as competências dos indivíduos que compõem o universo da pesquisa; e o sétimo e oitavo capítulos apresentam sugestões para pesquisas futuras e as considerações finais dessa pesquisa.

\subsection{JUSTIFICATIVA}

O mercado de trabalho do profissional da informação tem crescido exponencialmente, em especial, conforme aponta o estudo de Loureiro e Jannuzzi (2007), devido ao advento da explosão informacional e evolução das tecnologias de informação. Entretanto, juntamente com a expansão desse mercado, aumentou também a necessidade de qualificação e educação continuada desse profissional, tendo em vista o contexto dinâmico e competitivo, característico da sociedade da informação.

O ambiente educacional tem contratado, nos últimos dez anos, uma quantidade significativa de profissionais da informação, em especial bibliotecários, para atuarem em bibliotecas e outras unidades de informação de universidades, escolas técnicas e de ensino fundamental e médio (BRASIL, 2014).

Devido à expansão da rede federal de ensino no Brasil, estão sendo criados muitos postos de trabalho para os bibliotecários. Somente na rede federal de educação profissional e tecnológica do Distrito Federal foram criados mais de dez campi desde 2008 até o final de 2014. (BRASIL. MINISTÉRIO DA EDUCAÇÃO, 2014a). Nessa perspectiva, diversas bibliotecas também foram criadas, não tendo, entretanto, dados ou informações a respeito do perfil e competências destes indivíduos que foram e estão sendo contratados, mediante concurso público. 
A partir da percepção dessa problemática, surgiram as dúvidas sobre quais seriam as competências necessárias ao profissional que atua no âmbito da educação profissional e tecnológica e a motivação para realização da presente pesquisa. A partir do questionamento levantado, foi desenvolvido um estudo para identificar o perfil e mapear as competências dos bibliotecários que atuam na rede federal de educação profissional e tecnológica do Distrito Federal.

\subsection{PROBLEMA}

A pesquisa procurou responder à seguinte indagação:

Quais são as competências requeridas dos bibliotecários que atuam na rede federal de educação profissional e tecnológica do Distrito Federal?

\subsection{OBJETIVOS}

\subsubsection{Objetivo Geral}

Mapear as competências dos bibliotecários que atuam na rede federal de educação profissional e tecnológica do Distrito Federal.

\subsubsection{Objetivos Específicos}

a) Mapear as competências necessárias ao desenvolvimento das atividades profissionais, segundo a percepção dos bibliotecários que atuam na Rede Federal de Educação Profissional e Tecnológica do Distrito Federal;

b) Verificar se as competências mapeadas estão em conformidade com as estratégias, planos e atribuições da instituição à qual os bibliotecários estão vinculados;

c) Identificar o perfil do bibliotecário que atua na Rede Federal de Educação Profissional e Tecnológica do Distrito Federal. 


\section{REVISÃO DE LITERATURA - COMPETÊNCIA E PERFIL PROFISSIONAL}

\subsection{AS ABORDAGENS SOBRE COMPETÊNCIA}

Diferentes dimensões e abordagens sobre o conceito de competência têm se destacado tanto em âmbito organizacional quanto no acadêmico. Neste estudo, optou-se por mencionar autores que relacionam o conceito ao ambiente profissional, tendo em vista o foco da pesquisa.

As primeiras percepções a respeito da noção de competência foram apresentadas, em 1973, por David McClelland, psicólogo e pesquisador norteamericano, que concentrou sua proposição na ideia de que comportamentos que proporcionavam resultados socialmente úteis - como aqueles relacionados à performance do indivíduo no trabalho - seriam objeto de mensuração. McClelland publicou, então, o artigo "Competence rather than Intelligence", em que as habilidades mensuradas deveriam ser traduzidas em resultado social prático, o que ele denominou "competência" (FLEURY \& FLEURY, 2001).

Em meio às teorias que versam sobre o tema "competência", destacam-se duas importantes correntes de pensamento: uma americana, onde a competência, segundo Parry (1996), é definida como "input" do indivíduo, ou seja, fundamentase nas características que a pessoa possui, como conhecimentos e atitudes, que influenciam a habilidade individual em relação ao seu desempenho profissional. A outra, francesa, compreende a competência como "output", isto é, a perspectiva de ação do indivíduo, com iniciativa e responsabilidade, em determinado contexto, utilizando-se de conhecimentos e habilidades pessoais, com o foco em agregação de valor e resultados.

Os principais autores norte-americanos sobre o tema conceituam competência da seguinte maneira:

a) Boyatzis (1982) interpreta competência como uma razoavelmente profunda parte permanente da personalidade de uma pessoa, que leva ou resulta em um desempenho efetivo e/ou superior em uma tarefa;

b) Para Spencer \& Spencer (1993), competência compreende uma característica intrínseca de um indivíduo. Para esse autor, a 
competência representa uma performance superior, dentro de uma tarefa ou situação;

c) Mirabile (1997) caracteriza competência como um conjunto de conhecimentos, habilidades e aptidões ou perfil associado ao alto padrão de desempenho no trabalho e cita como exemplos a capacidade de resolução de problemas, pensamento analítico e liderança.

Para os autores franceses, a competência pode ser definida como:

a) Le Boterf (1995) situa a competência no centro de três eixos: pessoa, formação educacional e experiência profissional. Ele define competência como um saber agir de forma responsável e reconhecida por outros indivíduos. O conceito contempla habilidades como: saber mobilizar, integrar e transferir conhecimentos e recursos, de acordo com o contexto profissional;

b) Zarifian (1999) construiu o conceito de competência a partir da compreensão de três elementos: a tomada de iniciativa e responsabilidade do indivíduo em situações profissionais; da inteligência prática para atuar em diferentes situações; e saber mobilizar grupos de pessoas, no intuito de atingir objetivos comuns.

No Brasil, o conceito de competência começou a ser discutido em âmbito acadêmico na década de 1990. Os pesquisadores deram início e esse debate com respaldo na literatura norte-americana, compreendendo as competências como input, ou seja, algo que o indivíduo possui. Os autores franceses, como Le Boterf (1995) e Zarifian (1999), e norte-americanos, como Boyatzis (1982), contribuíram para o enriquecimento conceitual das pesquisas brasileiras e influenciaram teóricos, os quais se destacam autores como Ruas (2001), Fleury \& Fleury (2001) e Dutra (2004).

Conforme afirmam Gomes et al. (2007), as abordagens brasileiras apontam para um marco conceitual onde as competências caracterizam-se como conhecimentos, habilidades e atitudes, que agregam valor econômico para a organização e valor social ao indivíduo. 
Nessa perspectiva, o conceito de competência assume as seguintes acepções, de acordo com os pesquisadores brasileiros:

a) Fleury e Fleury (2001, p. 188) definem competência como "[...] um saber agir responsável e reconhecido, que implica mobilizar, integrar, transferir conhecimentos, recursos e habilidades, que agreguem valor econômico à organização e valor social ao indivíduo";

b) Para Ruas (2001), a questão das competências refere-se aos saberes e capacidades individuais, ao inter-relacionamento destes saberes entre os indivíduos; e a demanda da organização em seus processos de trabalho e relações com o mercado, isto é, a "[...] capacidade de saber agir em um contexto profissional, de forma responsável e legitimada, mediante a mobilização, integração e transferência de conhecimentos habilidades e capacidades em geral";

c) Carbone et al. (2006) estabeleceram uma relação entre as correntes norte-americana e francesa, para expressar o entendimento sobre competência. Os autores definem as competências como combinações inter-relacionadas de conhecimentos, habilidades e atitudes imanentes ao indivíduo e evidenciadas pelo desempenho profissional dentro de determinado contexto organizacional, que agregam valor a pessoas e organizações;

d) Ruzzarin, Amaral e Simionovschi (2006), baseando-se nas várias definições encontradas na literatura, conceituam competência como "[...] características possíveis de serem verificadas nas pessoas, incluindo conhecimentos, habilidades e atitudes que viabilizam uma performance superior". Os autores associam esses conhecimentos às competências técnicas e as habilidades e atitudes às competências comportamentais demandadas para cada função.

\subsection{ATRIBUTOS DA COMPETÊNCIA}

Verificou-se, por meio da literatura estudada, que o conceito de competência apresenta inúmeras definições, de acordo com a percepção de cada autor e em relação ao contexto em que está inserido. Além disso, conforme a concepção adotada, esses autores expõem diferentes atributos de competência, 
para representar características dos indivíduos, que estão implícitas nos conceitos apresentados.

Para Amaral et al. (2008), a competência do profissional está diretamente relacionada à aplicação pertinente de seus atributos de competência, ou seja, dos conhecimentos, habilidades e atitudes que o indivíduo possui e que estejam em conformidade com a função que ele exerce.

Le Boterf (2003) caracteriza esses atributos como recursos de competência e os qualifica da seguinte maneira:

a) saber agir com pertinência. Envolve as seguintes capacidades: ir além do que está preestabelecido; iniciativa e negociação; fazer escolhas e assumir riscos; reagir a casualidades; inovação; assumir responsabilidades; responder a situações complexas;

b) saber mobilizar saberes e conhecimentos em um contexto: aplicar conhecimentos e habilidades, de acordo com a situação;

c) saber integrar saberes múltiplos e heterogêneos: convergir diferentes conhecimentos e habilidades em função das exigências e situações dadas;

d) saber transpor: capacidade de adaptação e cognição;

e) saber envolver-se: capacidade de propor alternativas e engajar-se com o trabalho.

Invernizzi (2001) observa que a noção de competência apresenta-se sob diversas perspectivas, a depender do contexto em que se insere. Contudo, a autora enfatiza três atributos relevantes, que evidenciam um indivíduo competente:

a) o "saber", que compreende os aspectos práticos, técnicos e científicos, obtidos através de experiência profissional ou educação formal;

b) o "saber agir ou saber fazer", que corresponde à habilidade de transferência de conhecimento a situações concretas; e

c) o "saber ser", que está ligado diretamente às características de personalidade e à capacidade de relacionamento sociocultural do indivíduo. 
Fundamentando-se na teoria de Le Boterf, Fleury \& Fleury (2001) apresentaram, no Quadro 1, as seguintes definições, em relação aos atributos de competência:

Quadro 1 - Atributos de competência.

\begin{tabular}{|c|l|}
\hline $\begin{array}{c}\text { Saber agir } \\
\text { recursos }\end{array}$ & Saber o que e por que faz. Saber julgar, escolher, decidir. \\
\hline Saber comunicar & Criar sinergia e mobilizar recursos e competências. \\
\hline Saber aprender & $\begin{array}{l}\text { Trabalhar os conhecimentos e a experiência, rever modelos } \\
\text { mentais: saber desenvolver-se. }\end{array}$ \\
\hline $\begin{array}{c}\text { Saber engajar-se e } \\
\text { comprometer-se }\end{array}$ & Saber empreender, assumir riscos. Comprometer-se. \\
\hline $\begin{array}{c}\text { Saber assumir } \\
\text { responsabilidades }\end{array}$ & $\begin{array}{l}\text { Ser responsável, assumindo riscos e consequências de suas ações e } \\
\text { sendo por isso reconhecido. }\end{array}$ \\
\hline Ter visão estratégica & $\begin{array}{l}\text { Conhecer e entender o negócio da organização, o seu ambiente, } \\
\text { identificando oportunidades e alternativas. }\end{array}$ \\
\hline
\end{tabular}

Fonte: Fleury \& Fleury (2001).

\subsection{DESENVOLVIMENTO DE COMPETÊNCIAS}

Segundo Rodrigues e Muniz (2010, p. 5), as competências podem ser desenvolvidas e aperfeiçoadas, no sentido de contribuir para as transformações e atender às reais necessidades das organizações contemporâneas. As autoras salientam que para o desenvolvimento e aperfeiçoamento de competências, "[...] faz-se necessário um planejamento que conduza a um direcionamento e aprimoramento, estimulando o crescimento intelectual e profissional dos indivíduos". Acreditam, ainda, que a evolução das pessoas no ambiente organizacional está associada ao seu desempenho, à capacidade de adaptar-se às situações e ao desenvolvimento de competências e de habilidades adequados à execução de suas funções no trabalho.

Moura e Bitencourt (2006, p. 5) relacionam os atributos de competência ao desenvolvimento de competências. Para as autoras, "[...] o desenvolvimento de competências procura o equilíbrio entre o saber, o saber-fazer e o saber-agir [...]", ou seja, as competências dos indivíduos são desenvolvidas a partir do inter- 
relacionamento entre os conhecimentos teóricos adquiridos, a experiência profissional e a junção desses dois atributos para a tomada de decisões. Moura e Bitencourt salientam, ainda, que a identificação desses atributos em ambiente organizacional é essencial para o estudo de desenvolvimento de competências e que, geralmente, estes se encontram associados às competências organizacionais e à cultura da organização. Assim sendo, as autoras atestam que, identificando-se as competências e principais valores da cultura organizacional, será possível a verificação das competências requeridas dos indivíduos que atuam nesse contexto.

Na figura 1, Ruzzarin, Amaral e Simionovschi (2006) representam a vinculação entre as competências organizacionais, as competências genéricas (de grupos), as competências específicas dos indivíduos e os objetivos estratégicos na organização:

Figura 1 - Articulação entre competências essenciais, de grupos e individuais.

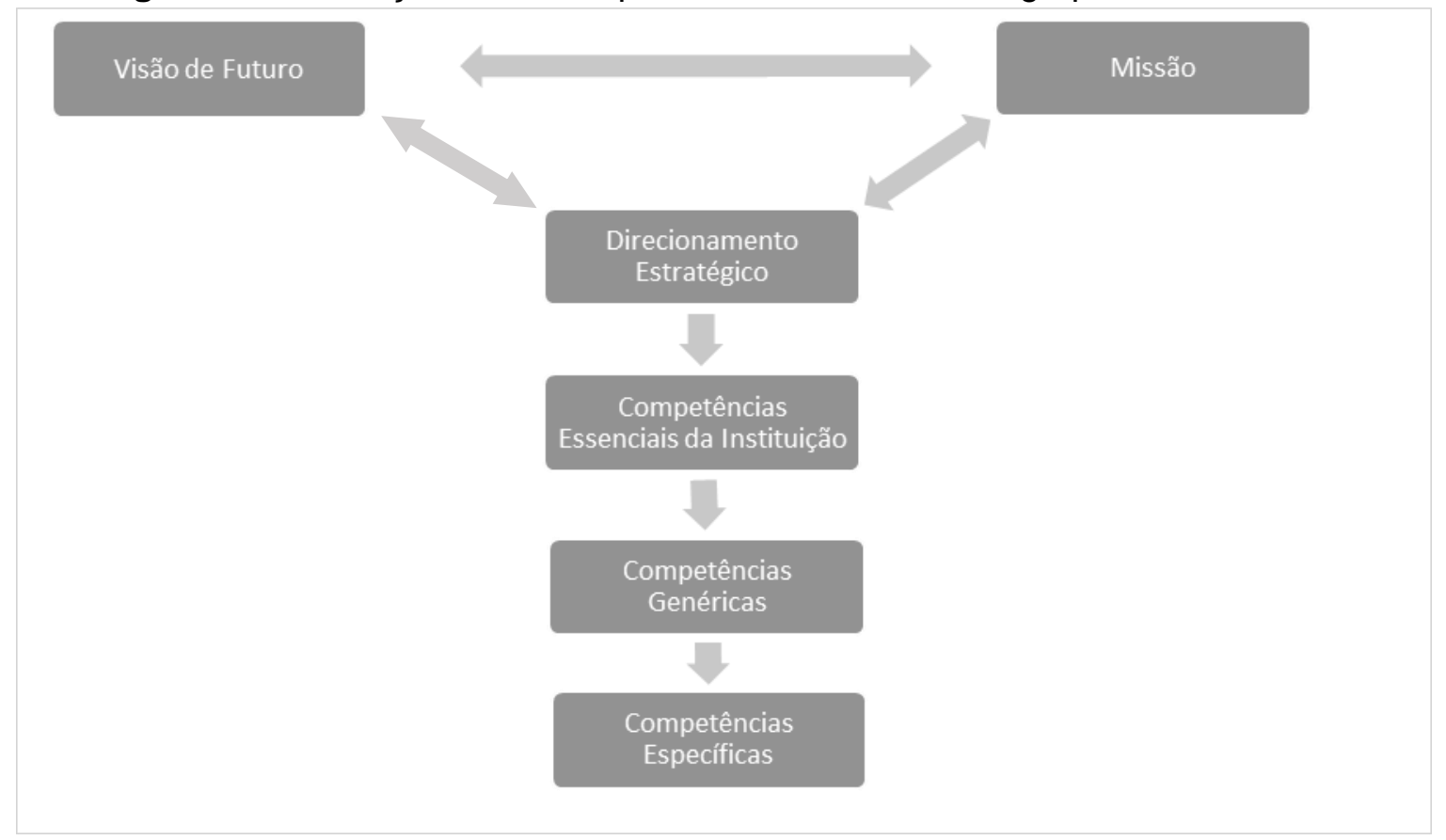

Fonte: Ruzzarin, Amaral e Simionovschi (2006).

\subsubsection{Competências Profissionais}

Segundo Le Boterf (2003), o conceito de "competência", associado ao ambiente profissional, angariou importância somente a partir da década de 1980 . Previamente a esse período era a ideia de "qualificação" que prevalecia. Observa- 
se que o vocábulo "qualificação" foi utilizado em um período contextualizado pela estabilidade das profissões. O termo competência surgiu em uma época cercada de incertezas e instabilidade socioeconômica, onde as habilidades individuais começaram a ser visualizadas como uma vantagem competitiva.

Zarifian (2003) esclarece que é um equívoco a tentativa de distinção entre os temas "qualificação" e "competência", pois não são ideias antagônicas, mas sim associadas. A qualificação correlaciona-se com os recursos cognitivos, comportamentais, entre outros, que o indivíduo adquire ao longo do tempo e que agregam valor à sua atividade profissional. A competência diz respeito à forma como esses recursos são aplicados em situações concretas. O autor afirma ainda, que a competência é a qualificação sob uma nova perspectiva, um modelo emergente, que determinou um novo período histórico.

A partir de uma concepção de desenvolvimento de competências profissionais, Le Boterf (1995) relaciona um tipo de conhecimento a uma função específica na organização e propõe uma ação para que esse conhecimento seja adquirido, conforme o quadro 2.

Quadro 2 - Desenvolvimento de competências nas organizações.

\begin{tabular}{|c|l|l|}
\hline \multicolumn{1}{|c|}{ Tipo } & \multicolumn{1}{|c|}{ Função } & \multicolumn{1}{c|}{ Desenvolvimento } \\
\hline Conhecimento Teórico & $\begin{array}{l}\text { Entendimento, } \\
\text { interpretação }\end{array}$ & $\begin{array}{l}\text { Educação formal e } \\
\text { continuada. }\end{array}$ \\
\hline $\begin{array}{c}\text { Conhecimento sobre os } \\
\text { procedimentos }\end{array}$ & Saber como proceder & $\begin{array}{l}\text { Educação formal e } \\
\text { experiência profissional }\end{array}$ \\
\hline Conhecimento empírico & Saber como fazer & Experiência profissional \\
\hline Conhecimento social & Saber como comportar-se & $\begin{array}{l}\text { Experiência social e } \\
\text { profissional }\end{array}$ \\
\hline Conhecimento cognitivo & $\begin{array}{l}\text { Saber como lidar com a } \\
\text { informação, saber aprender }\end{array}$ & $\begin{array}{l}\text { Educação formal e } \\
\text { continuada e experiência } \\
\text { social e profissional }\end{array}$ \\
\hline
\end{tabular}

Fonte: Le Boterf (1995).

Zarifian (1999) diferencia as seguintes competências em uma organização:

a) competências sobre processos: os conhecimentos do processo de trabalho; 
b) competências técnicas: conhecimentos específicos sobre 0 trabalho que deve ser realizado;

c) competências sobre a organização: saber organizar os fluxos de trabalho;

d) competências de serviço: aliar à competência técnica a pergunta: qual o impacto que este produto ou serviço terá sobre o consumidor final?

e) competências sociais: saber ser, incluindo atitudes que sustentam os comportamentos das pessoas; o autor identifica três domínios destas competências: autonomia, responsabilização e comunicação.

Ruzzarin, Amaral e Simionovschi (2006), associam a competência profissional à estratégia da organização (missão, visão e valores), conforme a figura 2.

Figura 2 - Modelo baseado em competências.

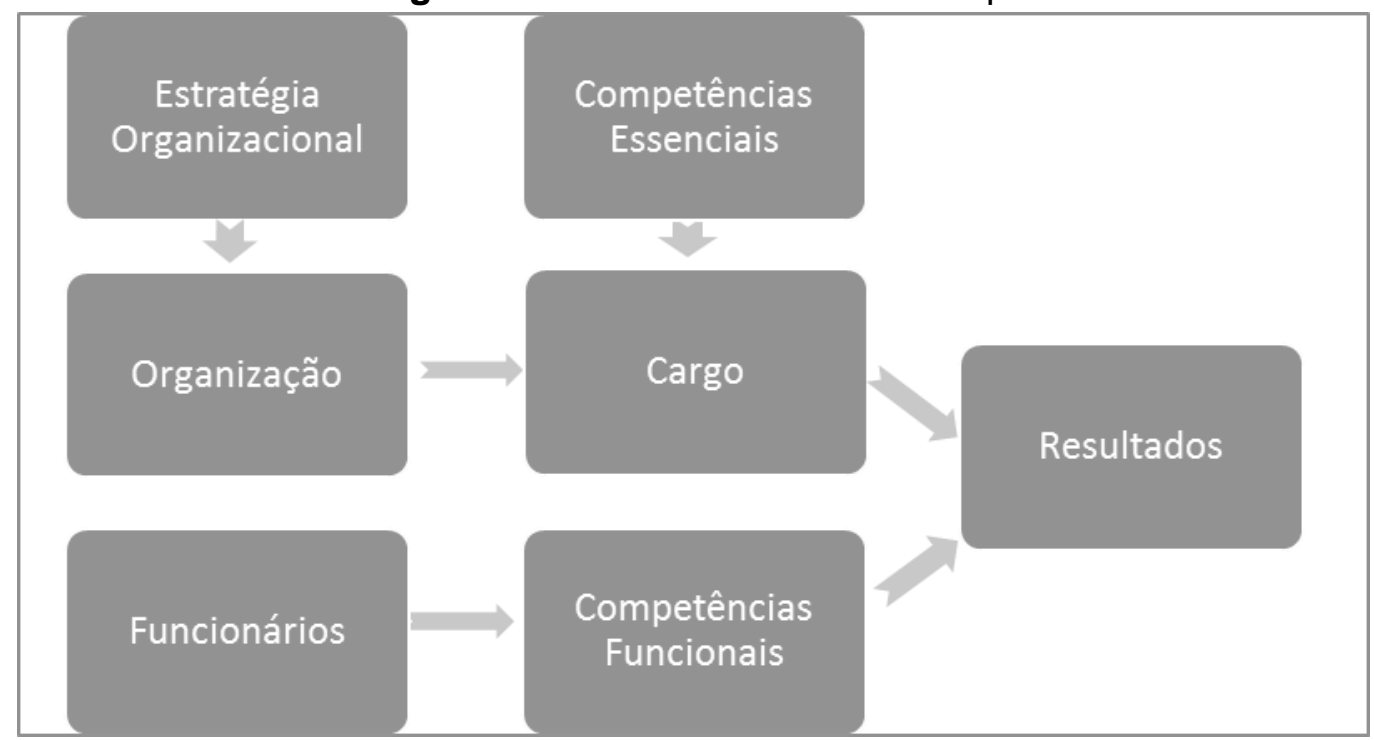

Fonte: Ruzzarin, Amaral e Simionovschi (2006).

\subsubsection{Competências Individuais}

Picchiai (2010, p. 78) define competências individuais como aquelas que "[...] tornam o indivíduo único [...]" e categorizam-nas em: 
a) universais: competências que 0 indivíduo possui e podem ser utilizadas em um vasto campo de atuação. Exemplo: flexibilidade, adaptabilidade, iniciativa, responsabilidade, etc.; e

b) específicas: são as competências técnicas, ou seja, aquelas relacionadas a um ambiente específico de atuação profissional.

A competência do indivíduo não é um estado, não se reduz a um conhecimento ou know how específico. Le Boterf (1995), afirma que cada indivíduo competente é único e não intercambiável. Sua competência é subjetiva e não pode ser informatizada.

Zarifian (2001) relaciona a competência individual ao resultado de múltiplas trocas de saberes e conexões entre atividades diferentes. Os saberes mobilizados na atividade de trabalho são dificilmente atribuídos a indivíduos ou a grupos de trabalhadores, no que se refere à forma como foram produzidos. Segundo Zarifian, estes saberes dependem do nível geral de desenvolvimento da sociedade, dos progressos que são realizados nos ambientes científico e tecnológico, dos conhecimentos providos pelo sistema educativo, dos relacionamentos estabelecidos entre as organizações, de acordo com seus ramos de atividade, das experiências que surgem da diversidade das situações de trabalho, etc. Nesse sentido, o autor afirma que é muito complexo avaliar como uma competência individual foi construída, tendo em vista que ela parte de um conjunto de conhecimentos e habilidades que foram sendo erigidas pelo indivíduo através de suas interações sociais ao longo do tempo.

É nesse contexto, de acordo com Ruas (2001), que a compreensão do conceito de competência surgiu como uma nova maneira de se pensar o papel e o desempenho do trabalho nas organizações. A competência individual, segundo Ruas, traduz-se na capacidade de mobilizar e aplicar os conhecimentos e habilidades adquiridos nos diferentes contextos a uma situação particular, na qual se aplicam recursos e atitudes próprias a situações específicas.

Dutra (2004) desenvolveu uma abordagem sobre competências individuais, associando-as a um contexto organizacional dinâmico. Partindo dessa 
premissa, o autor assinalou três abordagens metodológicas, no intuito de identificar as competências do indivíduo na organização:

a) A primeira é uma adaptação das definições presentes nos estudos de McClelland (1973). Nessa abordagem, são inicialmente citadas as pessoas consideradas pelos demais como tendo um desempenho acima da média. Em seguida, por meio de entrevistas individuais, são relacionadas as competências que distinguem essas pessoas, chamadas por McClelland de competências diferenciadoras, ou que atribuem uma performance superior. Por último, as competências identificadas são tabuladas e comparadas às estratégias e competências organizacionais consideradas pela organização como substanciais e distintas;

b) A segunda abordagem leva em consideração a relação natural entre as estratégias e competências organizacionais e as competências dos indivíduos. Esse enfoque, segundo Dutra (2004), possibilita à organização nivelar as estratégias e competências organizacionais em relação às competências individuais. Dessa forma, é possível estipular as competências fundamentais para a organização. Para tanto, essas competências são identificadas por meio de entrevistas com pessoaschave da organização, sendo posteriormente tabuladas e, por fim, trabalhadas com o conjunto dessas pessoas-chave, no intuito de se obter a melhor convergência entre os objetivos organizacionais e as competências dos trabalhadores;

c) A terceira abordagem relaciona-se com a segunda. Algumas competências individuais são requeridas a todos os colaboradores da organização e outras somente a determinado grupo de profissionais. $O$ processo de definição segue o mesmo parâmetro da segunda abordagem. Inicialmente, são verificados os fluxos de carreira existentes na organização; após essa etapa, são identificadas as competências existentes na organização em cada fluxo e, ao final, o resultado do levantamento é tratado em conjunto com as pessoas- 
chave da organização para se obter a melhor adequação entre os objetivos organizacionais e as competências dos trabalhadores.

\subsubsection{Competências do Profissional da Informação}

A discussão acerca das competências do profissional da informação necessita de maiores reflexões sobre suas práticas. Com o passar do tempo e de acordo com o avanço das tecnologias e das práticas profissionais, o bibliotecário está delineando uma representação mais sólida e abrangente da profissão. Ainda que suas atividades não estejam totalmente alheias aos suportes e às técnicas rotineiras, procuram privilegiar o acesso à informação, independente do contexto em que se encontre. "Seja ele bibliotecário, gerente, gestor, analista da informação, ou dos programas e recursos informacionais, especialista ou vigilante da informação tecnológica, sua representação social difere muito daquela do bibliotecário tradicional" (BUFREM \& PEREIRA, 2004, p. 171).

De acordo com a Special Library Association (1998 apud BELLUZZO, 2011) existem dois tipos de competências para os bibliotecários que atuam em bibliotecas especializadas no século 21: as profissionais, que compreendem as habilidades e os conhecimentos a serem utilizados para oferecer os diferentes produtos e serviços; e as pessoais onde são consideradas as habilidades, atitudes e valores que permitem trabalhar de forma eficiente e eficaz.

O mercado de trabalho exige profissionais dinâmicos, que não se limitam a cumprir rotinas ou desenvolver apenas trabalhos operacionais. E de acordo com Baptista e Mueller (2005, p.36):

\footnotetext{
Existe uma demanda por um profissional possuidor de uma visão holística, polivalente ou multiespecializada pois, para o momento, não basta que esse profissional seja especializado em técnicas de transferência ou organização da informação: é preciso ser um estrategista e entender como funciona um mundo competitivo e globalizado, em constante transformação.
}

Atendo-se também a esses preceitos, Belluzzo (2011) realizou, em seu estudo, uma compilação de competências do profissional da informação nas organizações contemporâneas, em âmbito nacional e internacional. De acordo 
com a autora, o cenário internacional oferece muitas pesquisas e estudos desenvolvidos em diferentes momentos e abrangendo dimensões de contextos e necessidades distintas sobre o profissional da informação. Várias entidades internacionais trabalharam no sentido de delinear o perfil e identificar as competências do bibliotecário contemporâneo, destacando-se, na pesquisa de Belluzzo, instituições como a Federação Internacional de Informação e Documentação (FID), A Special Library Association, o Council of Europe, o Observatório da Profissão de Informação e Documentação, além de encontros e autores internacionais. Em âmbito internacional, Belluzzo destacou as competências:
a) de linguagem;
b) de relacionamento interpessoal;
c) em desenvolvimento de novos produtos de informação;
d) em comunicação e expressão;
e) em gestão de conteúdos e do conhecimento;
f) em gestão global da informação;
g) em mediação (entre criadores, provedores e usuários e as tecnologias da informação e comunicação);
h) gerenciais;
i) pedagógicas;
j) em relacionamento interpessoal;
k) sociais e políticas;
l) técnico-científicas; e
m) tecnológicas.

Conforme Beluzzo (2011), no contexto nacional, verifica-se uma evolução nas práticas do bibliotecário, considerando-se desde o surgimento do primeiro curso de biblioteconomia no país, na Biblioteca Nacional, no início da década de 1910 até 2011 com o advento das novas tecnologias informacionais e novas técnicas de gerenciamento. A autora ressalta que essa evolução está relacionada, também, aos avanços concernentes à formação desses profissionais, já que, tradicionalmente, a educação profissional oferecida aos bibliotecários conduzia suas práticas à execução operacional do ciclo informacional (geração, 
organização, disseminação e o uso da informação) e vinculava-o a determinados tipos de suporte.

Segundo a autora, os cursos ofertados estão se adequando às novas percepções de representação desse mesmo ciclo, onde o profissional da informação exerce um trabalho mais intelectual, atuando nos fluxos informacionais como mediador e não apenas um executor de rotinas técnicas. Nesse sentido, Belluzzo (2011) destaca as seguintes competências, citadas por diferentes autores nacionais:

a) em administração e gestão de recursos e unidades de informação;

b) em desenvolvimento de ações políticas, pedagógicas e de pesquisa;

c) em organização de redes e desenvolvimento de técnicas de análise da informação e indexação;

d) em gerência de unidades e sistemas de informação;

e) técnicas (relacionadas à organização dos registros do conhecimento);

f) teóricas (relacionadas à informação e documentação).

Diversas outras pesquisas também identificaram as principais competências relacionadas ao profissional da informação. Bufrem \& Pereira (2004) atribuem aos profissionais da informação as competências de leitura e interpretação, crítica e discursiva. Em sua pesquisa, as autoras apresentaram um quadro-síntese (quadro 3), sobre as principais competências do profissional da informação atribuídas por diversos pesquisadores brasileiros no XXVI ENEBD Encontro Nacional dos Estudantes de Biblioteconomia, Documentação, Ciência e Gestão da Informação, em Curitiba, Paraná, de 20 a 26 de julho de 2003. 
Quadro 3 - Competências sugeridas por alguns palestrantes no XXVI ENEBD.

\begin{tabular}{|c|l|}
\hline Professores & \multicolumn{1}{|c|}{ Competências } \\
\hline Bufrem (UFPR) & Leitura; interpretação; crítica; discursiva. \\
\hline Gonzáles de Gomes (UFRJ) & Mediação e relacional (ações). \\
\hline Marcondes (UFF) & De conteúdos e de atitudes. \\
\hline Monteiro (Faculdades INOVE) & $\begin{array}{l}\text { Preservar; contextualizar; concentrar e } \\
\text { distribuir as informações. }\end{array}$ \\
\hline Pacheco (PUC-PR) & $\begin{array}{l}\text { Capacidade de sistematizar as informações } \\
\text { alheias. }\end{array}$ \\
\hline Triska (UFPR) & $\begin{array}{l}\text { Encontrar; filtrar e organizar as } \\
\text { informações. }\end{array}$ \\
\hline Valentim (UEL) & $\begin{array}{l}\text { Ação intelectual; capacidade de reconhecer } \\
\text { e descrever conteúdos; capacidade de } \\
\text { associar acervos aos usuários e } \\
\text { responsabilidade social. }\end{array}$ \\
\hline
\end{tabular}

Fonte: Bufrem \& Pereira (2004).

O IV Encuentro de Directores de Escuelas de Bibliotecología y Ciencia de La Información del Mercosur citado no livro organizado por Valentim (2000) incluiu, em suas pautas, a discussão sobre as competências do profissional da informação no âmbito do Mercosul. Desse debate foi originado um documento onde as competências profissionais foram definidas como:

[...] o conjunto de habilidades, destrezas e conhecimentos que requerem contar com um profissional em qualquer disciplina, para cumprir com sua atividade especializada oferecendo um mínimo de garantia sobre os resultados de seu trabalho, tanto a seus clientes ou empregadores, como, em última instância, à sociedade da qual faz parte. Isso implica a satisfação minimamente aceitável de necessidades especializadas que uma sociedade precisa resolver de um modo previsível, reconhecido e verificável, sobre a base de certas normas ou parâmetros de atuação. (ENCUENTRO DE DIRECTORES DE ESCUELAS DE BIBLIOTECOLOGÍA Y CIENCIA DE LA INFORMACIÓN DEL MERCOSUR, 2000, apud, VALENTIM, 2000, p. 17, tradução nossa).

Além do conceito de competência profissional, resultou desse encontro uma categorização de competências desejáveis ao profissional egresso de Universidades do Mercosul, nas áreas de Biblioteconomia/Ciência da Informação, divididas em quatro grandes áreas, conforme o quadro 4: 
Quadro 4 - Competências desejáveis e exigíveis a um profissional egresso de uma universidade na área de Biblioteconomia/Ciência da Informação no Mercosul.

\begin{tabular}{|c|c|}
\hline $\begin{array}{c}\text { Competências em Comunicação e } \\
\text { Expressão }\end{array}$ & Competências Técnico-Científicas \\
\hline $\begin{array}{l}\text { 1. Formular e gerenciar projetos de informação; } \\
\text { 2. Aplicar técnicas de marketing, liderança e de } \\
\text { relações públicas; } \\
\text { 3. Capacitar e orientar os usuários para o melhor uso } \\
\text { das unidades de informação e seus recursos; } \\
\text { 4. Elaborar produtos de informação (bibliografias, } \\
\text { catálogos, guias, índices, DSI, etc.); } \\
\text { 5. Executar procedimentos automatizados próprios } \\
\text { de um ambiente informatizado; } \\
\text { 6. Planejar e executar estudos de usuários/clientes } \\
\text { da informação e formação de usuários/clientes da } \\
\text { informação. }\end{array}$ & $\begin{array}{l}\text { 1. Desenvolver e executar o processamento de } \\
\text { documentos em distintos suportes em unidades, } \\
\text { sistemas e serviços de informação; } \\
\text { 2. Coletar, registrar, armazenar, recuperar e difundir a } \\
\text { informação gravada em qualquer meio para os } \\
\text { usuários de unidades, serviços e sistemas de } \\
\text { informação; } \\
\text { 3. Elaborar produtos de informação (bibliografias, } \\
\text { catálogos, guias, índices, DSI, etc.); } \\
\text { 4. Utilizar e disseminar fontes, produtos e recursos } \\
\text { de informação em diferentes suportes; } \\
\text { 5. Reunir, valorar documentos e proceder ao seu } \\
\text { arquivamento; } \\
\text { 6. Preservar e conservar os materiais hospedados } \\
\text { nas unidades de informação; } \\
\text { 7. Selecionar e avaliar todo tipo de material para as } \\
\text { unidades de informação; } \\
\text { 8. Buscar, registrar, avaliar e difundir a informação } \\
\text { com fins acadêmicos e profissionais; } \\
\text { 9. Executar procedimentos automatizados próprios } \\
\text { de um ambiente informatizado; } \\
\text { 10. Planejar e executar estudo de } \\
\text { usuários/clientes da informação e formação de } \\
\text { usuários/clientes da informação; } \\
\text { 11. Planejar, constituir e manipular redes globais de } \\
\text { informação; } \\
\text { 12. Formular políticas de investigação em } \\
\text { Biblioteconomia e Ciência da Informação; } \\
\text { 13. Realizar investigaçães e estudos sobre } \\
\text { desenvolvimento e aplicação de metodologia de } \\
\text { elaboração e utilização do conhecimento registrado; } \\
\text { 14. Assessorar e intervir na elaboração de normas } \\
\text { jurídicas em Biblioteconomia e Ciência da } \\
\text { Informação; } \\
\text { 15. Assessorar na avaliação de coleções } \\
\text { bibliográficas-documentais; } \\
\text { 16. Realizar perícias no que se refere à } \\
\text { autenticidade, antiguidade, procedência e estado de } \\
\text { materiais impressos de valor biblioteconômico. } \\
\end{array}$ \\
\hline
\end{tabular}

Fonte: Compilado pela Autora, a partir de ENCUENTRO..., 2000, apud, VALENTIM, 2000, p.19-21, tradução nossa. 
Quadro 4 - Competências desejáveis e exigíveis a um profissional egresso de uma universidade na área de Biblioteconomia/Ciência da Informação no Mercosul. (cont.)

\begin{tabular}{|c|c|}
\hline Competências Gerenciais & Competências Sociais e Políticas \\
\hline $\begin{array}{l}\text { 1. Dirigir, administrar, organizar e coordenar } \\
\text { unidades, sistemas e serviços de informação; } \\
\text { 2. Formular e gerir projetos de informação; } \\
\text { 3. Aplicar técnicas de marketing, liderança e de } \\
\text { relações públicas; } \\
\text { 4. Buscar, registrar, avaliar e difundir a } \\
\text { informação com fins acadêmicos e } \\
\text { profissionais; } \\
\text { 5. Elaborar produtos de informação } \\
\text { (bibliografias, catálogos, guias, índices, DSI, } \\
\text { etc.); } \\
\text { 6. Assessorar no planejamento dos recursos } \\
\text { econômico-financeiros e humanos do setor; } \\
\text { 7. Planejar, coordenar e avaliar a preservação e } \\
\text { conservação do acervo documental; } \\
\text { 8. Planejar e executar estudos e formação de } \\
\text { usuários/clientes da informação; } \\
\text { 9. Planejar, constituir e manipular redes } \\
\text { regionais e globais de informação. }\end{array}$ & $\begin{array}{l}\text { 1. Selecionar e avaliar todo tipo de material } \\
\text { para as unidades de informação; } \\
\text { 2. Buscar, registrar, avaliar e difundir a } \\
\text { informação com fins acadêmicos e } \\
\text { profissionais; } \\
\text { 3. Assessorar e intervir na formulação de } \\
\text { políticas de informação; } \\
\text { 4. Assessorar no planejamento dos recursos } \\
\text { econômico-financeiros e humanos do setor; } \\
\text { 5. Planejar e executar estudos e formação de } \\
\text { usuários/clientes da informação; } \\
\text { 6. Promover atitude crítica e criativa em relação } \\
\text { à resolução de problemas e questões de } \\
\text { informação; uma atitude aberta e interativa com } \\
\text { 7. Fomentar uma } \\
\text { os diversos atores sociais (políticos, } \\
\text { empresários, educadores, trabalhadores e } \\
\text { profissionais de outras áreas, instituições e } \\
\text { cidadãos em geral); } \\
\text { 8. Identificar as novas demandas sociais de } \\
\text { informação: } \\
\text { 9. Contribuir para definir, consolidar e } \\
\text { desenvolver o mercado de trabalho na área; } \\
\text { 10. Atuar coletivamente com seus pares no } \\
\text { âmbito das instituições sociais, com o objetivo } \\
\text { de promoção e defesa da profissão; } \\
\text { 11. Formular políticas de investigação em } \\
\text { Biblioteconomia e Ciência da Informação; } \\
\text { 12. Assessorar e intervir na elaboração de } \\
\text { normas jurídicas em Biblioteconomia e Ciência } \\
\text { da Informação. }\end{array}$ \\
\hline
\end{tabular}

Fonte: Compilado pela Autora, a partir de ENCUENTRO..., 2000, apud, VALENTIM, 2000, p.19-21, tradução nossa.

Em trabalho apresentado no XVI Seminário Nacional de Bibliotecas Universitárias (SNBU), Rodrigues e Muniz (2010) elencaram competências que consideram essenciais ao bibliotecário que atua em ambiente acadêmico:

a) competências gerenciais: habilidades em planejamento e liderança de equipes; 
b) competências individuais: proatividade, dinamismo, iniciativa, criatividade, flexibilidade, educação continuada, atualização profissional constante e domínio de idiomas estrangeiros;

c) competências para atuação em contexto multidisciplinar;

d) competências técnicas: habilidades em tecnologias da informação.

Barbosa (2014), questionou, no Encontro Nacional de Pesquisa em Ciência da Informação (ENANCIB), o modelo de competências para o profissional da informação proposto nas Diretrizes Curriculares para os cursos de Biblioteconomia, do Ministério da Educação. A autora argumenta que as competências constantes nas diretrizes são de cunho genérico e que deveriam explorar mais as competências, conforme parâmetros direcionados a unidades de informação especializadas e propôs que essas competências poderiam ser definidas a partir dos seguintes eixos temáticos:

a) competências estratégicas: domínio do conceito econômico da informação; conhecimento do mercado; conhecimento de técnicas de monitoramento informacional; conhecimento do negócio da organização; conhecimento do contexto político e econômico; senso empreendedor;

b) competências essenciais ao bibliotecário escolar: teoria e técnicas de letramento; teorias e técnicas de leitura; teorias e técnicas de didática;

c) competências em tecnologia: capacidade de utilização de sistemas especiais e especialistas, sistemas de estudos bibliométricos e de frequência de informação (data mining ${ }^{1}$ e data warehouse ${ }^{2}$ ).

\footnotetext{
${ }^{1}$ Mineração de dados (tradução nossa).

${ }^{2}$ Armazenamento de dados (tradução nossa).
} 


\subsection{MAPEAMENTO DE COMPETÊNCIAS}

Um mapeamento de competências eficiente pode contribuir de inúmeras maneiras para a organização. Pode ser encarado como peça chave para se obter vantagem competitiva, prever a necessidade de capacitação dos colaboradores da organização, pode ser utilizado para detectar os pontos fortes e aqueles que precisam ser melhorados, em relação ao capital humano, entre outros.

De acordo com Carbone et al. (2006), o mapeamento de competências pressupõe diagnosticar as competências internas já existentes na instituição, no intuito de identificar a dissonância entre as competências necessárias ao contexto organizacional e aquelas que, de fato, os colaboradores e a instituição possuem.

Brandão e Bahry (2005) defendem que o mapeamento de competências tem como pressuposto a identificação de "[...] gaps ou lacunas de competências". Segundo os autores, para detectar essas lacunas é preciso identificar as competências necessárias para que se alcancem os objetivos organizacionais e cotejá-las àquelas já existentes na organização. Nesse sentido, eles propuseram alguns pontos a serem considerados na metodologia para a identificação das competências em uma organização:

a) verificar as competências (organizacionais e profissionais) necessárias ao cumprimento dos objetivos da organização (pesquisa documental);

b) realizar a coleta de dados com pessoas-chave da organização, para que os dados coletados sejam comparados com a análise documental;

c) utilizar técnicas de pesquisa, de acordo com o contexto: questionários estruturados, grupos focais, etc.;

d) representar, nos instrumentos de pesquisa, as competências profissionais de maneira clara, no intuito de reduzir a ambiguidade de interpretações;

e) evitar a elaboração de exposições longas e a utilização de termos técnicos que dificultem a compreensão da pesquisa;

f) evitar irrelevâncias e obviedades; 
g) utilizar verbos que expressem uma situação concreta, como: analisar, organizar, selecionar, comunicar, avaliar e formular;

h) realizar um pré-teste.

Ruzzarin e Simionovschi (2010) ressaltam a importância de se levar em consideração a estratégia organizacional durante o processo de mapeamento de competências. Salientam ainda que o mapeamento deve partir da observação dos processos organizacionais e não apenas das atividades desempenhadas por determinado cargo e propõem um fluxo de procedimentos, para que se obtenha um mapeamento de competências alinhado ao contexto da organização:

a) identificação da estratégia: entender quais os objetivos e estratégias organizacionais;

b) verificação da estrutura organizacional: identificar os níveis hierárquicos;

c) definição da profundidade de imersão na estrutura: verificar as necessidades em relação ao cargo a ser mapeado;

d) listagem de atividades: relacionar as atividades inerentes ao cargo a ser mapeado;

e) agrupamento de atividades por processos: relacionar as atividades desenvolvidas pelos profissionais no contexto organizacional;

f) questionamento da visão de futuro: verificar se as atividades listadas são realmente necessárias à estratégia organizacional;

g) encaixe dos processos conforme o escopo de atuação: relacionar o cargo em seu correto grupo ocupacional;

h) descrição das responsabilidades do cargo: listar as incumbências relativas ao cargo;

i) definição das competências e formação: conectar as competências às responsabilidades.

A figura 3 mostra, de forma simplificada, a abordagem para mapeamento das competências, referentes ao cargo, proposta por Ruzzarin e Simionovschi (2010). 
Figura 3 - Abordagem para mapeamento da estrutura de cargos.

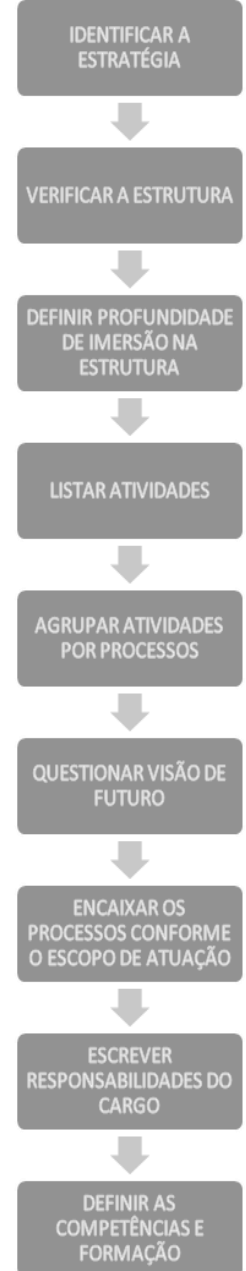

Fonte: Ruzzarin e Simionovschi (2010).

Amaral et al. (2008), pautando-se nos trabalhos desenvolvidos por Ruzzarin (2002), desenvolveram o quadro 5, com recomendações para 0 processo de mapeamento de competências. 
Quadro 5 - Passos para a realização do mapeamento.

\begin{tabular}{|l|l|}
\hline \multicolumn{1}{|c|}{ Passos } & \multicolumn{1}{c|}{ Descrição } \\
\hline $\begin{array}{l}\text { Buscar as percepções de } \\
\text { competências organizacionais. }\end{array}$ & $\begin{array}{l}\text { Extrair da cultura e da estratégia organizacional todas as } \\
\text { informações capazes de definir atributos de } \\
\text { competência válidos para todos na organização. }\end{array}$ \\
\hline $\begin{array}{l}\text { Buscar as percepções de } \\
\text { competências para os cargos a } \\
\text { serem mapeados. }\end{array}$ & $\begin{array}{l}\text { Extrair as informações específicas acerca dos cargos que } \\
\text { permitirão elencar os atributos de competência } \\
\text { necessários a cada um deles. }\end{array}$ \\
\hline $\begin{array}{l}\text { Extrair das percepços os } \\
\text { atributos de competência } \\
\text { imprescindíveis para a eficácia } \\
\text { do colaborador no cargo. }\end{array}$ & $\begin{array}{l}\text { Gerar, para cada cargo, uma lista dos atributos } \\
\text { (conhecimentos, habilidades e atitudes) necessários ao } \\
\text { melhor desempenho do profissional no cargo. }\end{array}$ \\
\hline $\begin{array}{l}\text { Agrupar os atributos similares. } \\
\text { Definir e formar as } \\
\text { competências para cada cargo. }\end{array}$ & $\begin{array}{l}\text { Analisar o conjunto dos atributos, buscando } \\
\text { similaridades que facilitem a criação de competências. } \\
\text { Definir competências específicas através dos grupos de } \\
\text { atributos. }\end{array}$ \\
\hline
\end{tabular}

Fonte: Amaral et al. (2008).

\subsubsection{Mapeamento de Competências em Unidades de Informação}

De acordo com Faria et al. (2005), os modelos de mapeamento de competências em unidades de informação devem ser delineados a partir das competências essenciais levantadas e definidas com base na pesquisa de valores institucionais e profissionais e aplicados em amostragens que relacionem essas competências aos perfis do profissional da informação. Os autores sustentam que, dessa forma, o mapeamento resultaria na constituição de bancos de indicadores de competência, que poderiam servir de subsídio à concepção de estudos prospectivos, para identificação de prioridades e/ou à definição de políticas organizacionais.

Para Amorim \& Amaral (2011) o fundamento para o mapeamento de competências em unidades de informação decorre da necessidade de nivelamento de demandas, serviços, produtos, recursos e pessoal, no intuito de se obter um planejamento condizente com a realidade da organização e anteporse a futuros desafios. Adaptando sua pesquisa aos métodos de mapeamento de competências existentes na literatura, Amorim e Amaral desenvolveram uma metodologia para o mapeamento de competências em unidades de informação 
(no caso, uma biblioteca setorial da Universidade de São Paulo, USP). A metodologia compreendeu um conjunto de seis atividades:

a) caracterização da unidade de informação: compreensão e avaliação da missão, objetivos, visão e planejamento estratégico da instituição, por meio da aplicação da técnica SWOT (Strengths, Weaknesses, Opportunities and Threats) ${ }^{3}$, no intuito de diagnosticar os ambientes interno e externo da organização;

b) mapeamento dos processos da unidade de informação: compreendido pelo detalhamento dos processos organizacionais;

c) coleta das percepções sobre a competência da equipe de bibliotecários da instituição: percepções relacionadas à atuação dos bibliotecários;

d) conversão das percepções em características positivas: tradução das percepções mapeadas;

e) classificação das características positivas em atributos de competência: a classificação foi realizada de acordo com o glossário de competências disponível no trabalho de Amaral et al. (2008);

f) elaboração dos indicadores de competência da equipe: última atividade do mapeamento, foi elaborado a partir da análise dos atributos de competência coletados.

\footnotetext{
${ }^{3}$ Forças, Fraquezas, Oportunidades e Ameaças (tradução nossa).
} 
Quadro 6 - Modelo para o mapeamento de competências em inteligência competitiva.

\begin{tabular}{|c|c|c|c|}
\hline Atividade & Descrição & Ferramentas & Resultados \\
\hline chis & Caracterizar a unidade de informação & $\begin{array}{c}\text { Técnica de } \\
\text { análise SWOT }\end{array}$ & $\begin{array}{l}\text { Missão } \\
\text { Objetivos } \\
\text { Visão }\end{array}$ \\
\hline 2 & Mapeamento de processos & $\begin{array}{l}\text { Observação } \\
\text { Sistema de } \\
\text { Gestão da } \\
\text { Qualidade } \\
\end{array}$ & Processos \\
\hline 3 & $\begin{array}{l}\text { Coleta das percepções sobre a competência } \\
\text { da equipe }\end{array}$ & \multirow[t]{2}{*}{$\begin{array}{l}\text { Formulário de } \\
\text { coleta de } \\
\text { percepções de } \\
\text { competências }\end{array}$} & $\begin{array}{l}\text { Percepções de } \\
\text { competência } \\
\text { da equipe }\end{array}$ \\
\hline 4 & $\begin{array}{l}\text { Conversăo das percepções em } \\
\text { características positivas }\end{array}$ & & $\begin{array}{c}\text { Características } \\
\text { positivas }\end{array}$ \\
\hline 5 & $\begin{array}{l}\text { Classificação das características positivas em } \\
\text { atributos de competência }\end{array}$ & $\begin{array}{l}\text { Glossário de } \\
\text { atributos de } \\
\text { competências }\end{array}$ & $\begin{array}{l}\text { Atributos de } \\
\text { competência } \\
(\mathrm{CHA})\end{array}$ \\
\hline 6 & $\begin{array}{l}\text { Elaboração dos indicadores de competência } \\
\text { da equipe: } \\
\text { - Indicador de importância dos atributos de } \\
\text { competência; } \\
\text { - Indicador do nível de domínio dos atributos } \\
\text { de competência pela equipe } \\
\end{array}$ & $\begin{array}{l}\text { Planilha } \\
\text { eletrônica }\end{array}$ & $\begin{array}{l}\text { Indicadores de } \\
\text { competências } \\
\text { da equipe }\end{array}$ \\
\hline
\end{tabular}

Fonte: Adaptado de RUZZARIN et al. (2002); MCLAGAN (1997) e AMARAL et al. (2008) apud Amorim e Amaral 2011.

Rodrigues e Muniz (2010) enfatizam a importância dos estudos sobre gestão por competências (GC) no processo de mapeamento das competências do profissional da informação. Afirmam que a GC denota um importante artifício para que o profissional esteja habilitado a gerenciar os processos e o desempenho de equipes. Salientam ainda que a aplicação dos conceitos associados à GC nas unidades de informação possibilita a reorganização dos serviços, a efetivação de mudanças e permite ao profissional da informação o planejamento fundamentado de sua atuação. Nesse sentido, as autoras desenvolveram, em seu estudo, uma metodologia para o mapeamento de competências em unidades de informação, onde procederam às seguintes etapas:

a) pesquisa bibliográfica e eletrônica acerca das competências do profissional da informação;

b) pesquisa de campo, em que foram realizadas entrevistas com bibliotecários; e

c) aplicação de questionários, com temáticas sobre a importância da Gestão por Competências, as competências e as habilidades 
desejáveis ao profissional da informação, atuação no mercado de trabalho e observação das práticas profissionais.

Nessa perspectiva, Sampaio (2010) desenvolveu seu estudo sobre mapeamento de competências em unidades de informação, com o foco no profissional que desenvolve atividades gerenciais. Sampaio destaca que, no contexto de unidades informacionais, a realização de um mapeamento de competências individuais, sobretudo gerenciais, tem como objetivos, fatores como o conhecimento das competências essenciais pertinentes à organização à qual a unidade está subordinada e competências essenciais concernentes à própria unidade de informação como, por exemplo: perspectiva sistêmica, atividades desempenhadas, necessidades dos usuários, procedimentos administrativos, recursos disponíveis e até mesmo técnicas de marketing. A autora propõe etapas para a efetivação do mapeamento de competências gerenciais em unidades de informação:

a) analisar o ambiente macro (externo) e interno (organização à qual a unidade de informação está subordinada), suas variáveis e principais características;

b) pesquisar e determinar as competências essenciais da organização mantenedora e da própria unidade de informação: verificar a missão, visão, objetivos, metas e estratégias;

c) realizar o mapeamento das competências, de acordo com as informações que foram coletadas.

Segundo Rossi, Costa e Pinto (2014), aplicar o mapeamento de competências em unidades de informação auxilia na identificação das aptidões dos colaboradores, para que os objetivos institucionais sejam alcançados. Desta forma, a aplicação do mapeamento e dos preceitos da gestão por competências influenciam positivamente na produtividade e motivação do profissional da informação, assim como contribui com o processo de seleção de novos colaboradores, conduzindo-os, a partir da análise de suas competências, aos setores adequados da unidade de informação. De acordo com os autores, além de proporcionar um melhor aproveitamento das competências existentes, a realocação dos profissionais e a contratação baseada no mapeamento prévio das 
competências, auxiliam na diminuição das lacunas existentes e contribuem para a eficiência no desempenho do trabalho.

\subsection{O BIBLIOTECÁRIO NA ERA DA INFORMAÇÃO}

\subsubsection{Caracterização da Sociedade da Informação}

A expressão "sociedade da informação", de acordo com Werthein (2000), passou a ser utilizada, nos últimos anos do século $X X$, em substituição ao conceito de "sociedade pós-industrial" e como uma maneira de apresentar o "novo paradigma técnico-econômico". Werthein atribuiu essa transformação à evolução da tecnologia da informação, que, segundo o autor, possibilitou implementar a lógica de redes, permitindo, por conseguinte, delinear resultados decorrentes da criatividade advinda da interação multifacetada, desafio quase impraticável no padrão tecnológico anterior.

Segundo Castells (2001), o surgimento da sociedade da informação, como uma nova estrutura social, está associado à manifestação de um novo modelo de desenvolvimento, que ele intitula de "informacionalismo", moldado, segundo o autor, pela reestruturação do modo capitalista de produção, no final do século XX. Para Castells, a nova sociedade, decorrente desse processo de transformação, é capitalista e informacional e, consoante à percepção de Werthein (2000), Castells associa esse novo paradigma à evolução da tecnologia da informação.

Contrapondo-se às ideias de Werthein (2000) e Castells (2001), Lazarte (2000) afirma que a qualificação da "sociedade da informação" apenas por sua dimensão econômica e tecnológica é uma escolha reducionista. O autor sustenta que a escolha dos critérios de interação técnico-econômicos pode ser adaptada a objetivos que sobrepujam a esfera econômica, abarcando, por exemplo, necessidades e interesses sociais centrados no ser humano e em suas realizações pessoais. Para Lazarte (2000, p.51),

[...] toda tecnologia, organização social e visão de mundo devem ser referenciadas no ser humano e suas necessidades, desde as mais essenciais até as mais sutis. A exploração dos novos potenciais oferecidos deve ser feita desde esta perspectiva, e não priorizando a necessidade de que o ser humano se adapte a uma mudança externa 
que lhe é imposta. A atenção aos valores humanos essenciais não só é possível, mas é necessária no desenho da utilização dos novos meios.

A publicação Sociedade da Informação no Brasil - Livro Verde (BRASIL. MINISTÉRIO DE CIÊNCIA E TECNOLOGIA, 2000) aborda, em profundidade, o tema "sociedade da informação" e as implicações dessa nova era para a sociedade brasileira. Nesse estudo, a sociedade da informação é entendida como um fenômeno global e representa uma mudança significativa na organização da sociedade e da economia. Nesse estudo, ressalta-se, ainda, a dimensão políticoeconômica da sociedade da informação, no tocante à contribuição da infraestrutura de informações para o desenvolvimento da sociedade e sua dimensão social, tendo em vista o potencial integrativo e inclusivo da coletividade, decorrente desse novo paradigma.

De acordo com Borges (2000), a sociedade da informação decorre de uma nova ordem, que teve suas origens nas mudanças de paradigmas ocorridas no final do século $X X$, tanto sob o enfoque socioeconômico, quanto cultural, político e tecnológico e que direcionou a sociedade a adquirir, sob essas mesmas perspectivas, novas exigências, estratégias e ações, em resposta à própria dinâmica evolutiva, onde a interdisciplinaridade foi considerada como elemento determinante.

$\mathrm{Na}$ figura 4, Borges (2000) caracteriza a abordagem tradicional, referindose ao período compreendido entre o início e meados do século XX. Nesse ínterim, segundo Borges, houve o predomínio da "especialização", onde o estudo das disciplinas se dava de maneira isolada. 
Figura 4 - Abordagem tradicional geral.

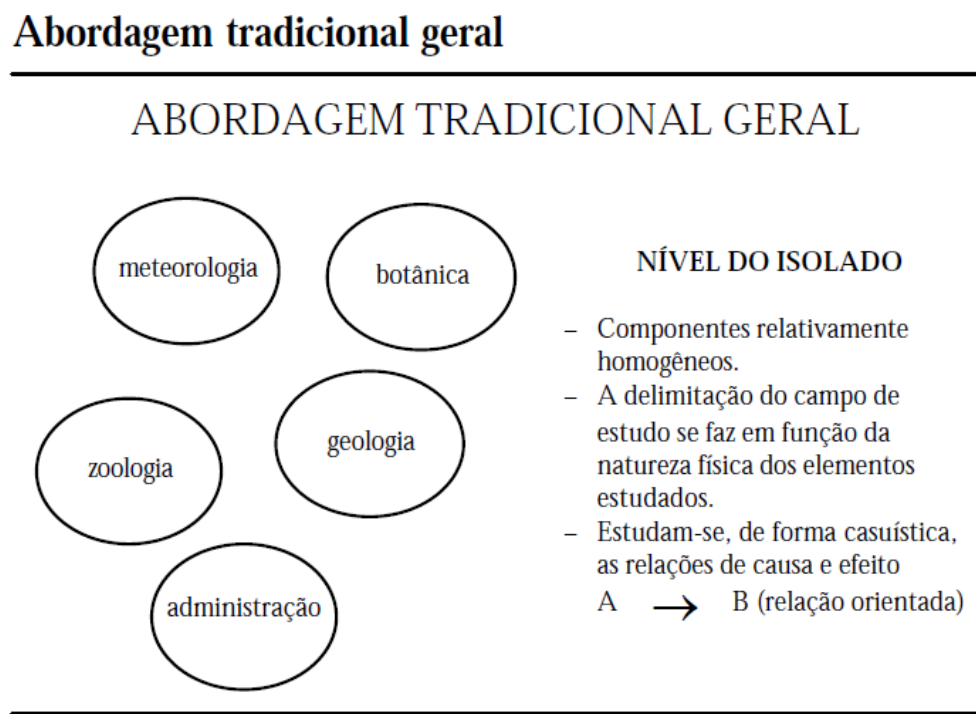

Fonte: Borges (2000).

Conforme a figura 5, Borges (2000) apresenta um esquema para ilustrar as mudanças paradigmáticas ocorridas a partir do final do século $X X$, às quais ela intitula de abordagem sistêmica. Segundo a autora, houve a passagem de um período de especialização, isolamento (conforme foi caracterizado na figura 4), para um período de síntese, onde ocorreu a integração entre as diversas disciplinas e áreas do conhecimento.

Figura 5 - Abordagem sistêmica.

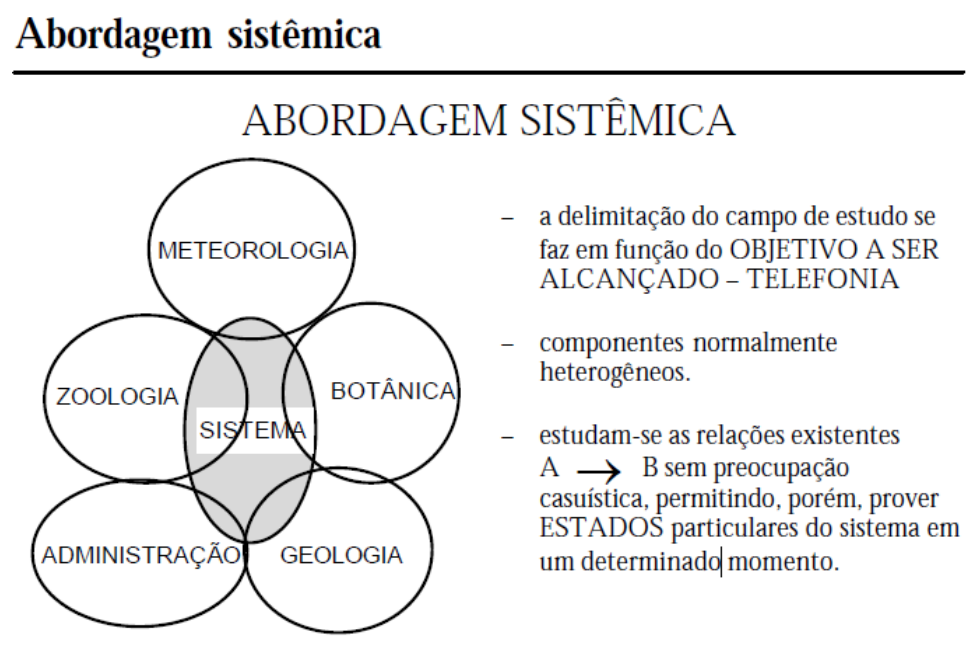

Fonte: Borges (2000). 
Em seu artigo, Borges (2000) também apresentou o resultado de estudo comparativo, enfatizando as mudanças de paradigma nas organizações sociais. No quadro 7 , a autora ressalta as diferenças entre as organizações que ela chama "da Segunda Onda", referindo-se àquelas existentes no período da sociedade industrial e as organizações "modernas", ou seja, as organizações procedentes da sociedade da informação e do conhecimento.

Quadro 7 - Comparativo entre a empresa da sociedade industrial e a empresa da sociedade da informação.

\begin{tabular}{|l|l|}
\hline \multicolumn{1}{|c|}{ Empresa da Sociedade Industrial } & Empresa da Sociedade da Informação \\
\hline Enfoque analítico/atomístico. & Enfoque macro/holístico. \\
\hline $\begin{array}{l}\text { Individualismo/predomínio/ } \\
\text { distanciamento entre as pessoas. }\end{array}$ & $\begin{array}{l}\text { Igualdade de } \\
\text { direitos/compartilhamento/ } \\
\text { participação. }\end{array}$ \\
\hline $\begin{array}{l}\text { Autoridade } \\
\text { centralizadora/paternalista/ } \\
\text { autocrática. }\end{array}$ & $\begin{array}{l}\text { Autoridade } \\
\text { adulta/facilitadora/democrática. }\end{array}$ \\
\hline $\begin{array}{l}\text { Continuidade num único nicho } \\
\text { profissional. Especialização excessiva. }\end{array}$ & $\begin{array}{l}\text { Opções múltiplas. Liberdade de } \\
\text { escolha. Visão generalizada. }\end{array}$ \\
\hline $\begin{array}{l}\text { Economia de escala/tendência ao } \\
\text { gigantismo e à centralização. }\end{array}$ & $\begin{array}{l}\text { Descentralização, resguardando-se a } \\
\text { integração. }\end{array}$ \\
\hline $\begin{array}{l}\text { Valorização da quantidade. } \\
\text { Valorização da qualidade associada à } \\
\text { quantidade. }\end{array}$ \\
\hline $\begin{array}{l}\text { Empresário avesso ao risco. Busca de } \\
\text { protecionismo. }\end{array}$ & $\begin{array}{l}\text { Empresário empreendedor. Criativo e } \\
\text { competitivo. }\end{array}$ \\
\hline $\begin{array}{l}\text { A grande alavanca é o dinheiro. } \\
\text { A grande alavanca é a informação/ o } \\
\text { conhecimento/a educação. }\end{array}$ \\
\hline $\begin{array}{l}\text { O sucesso é garantido pelo poder de } \\
\text { investimento em máquina e } \\
\text { instalações. }\end{array}$ & $\begin{array}{l}\text { A mente humana é o grande software. } \\
\text { O computador é o grande hardware. }\end{array}$ \\
\hline
\end{tabular}

Fonte: Borges (2000)

\subsubsection{O Perfil do Bibliotecário na Sociedade da Informação}

O conceito que tipifica o perfil do moderno profissional da informação (MIP) vem sendo discutido por vários autores desde o final da década de 1980. Dentre as principais características que compõem este perfil profissional estão: a adaptação ao meio e às mudanças, flexibilidade, criatividade, inovação, qualidade na atuação profissional, desempenho de funções gerenciais e atuação em 
diversas áreas, como por exemplo, marketing, inteligência competitiva, economia, etc. (GUIMARÃES, 1997).

Tarapanoff (1988), elaborou uma revisão da literatura nacional sobre as características e tendências do profissional da informação, na qual relacionou algumas variáveis a serem consideradas em um perfil possível do profissional da informação:

a) a interdisciplinaridade;

b) a necessidade do profissional da informação de conhecer a área de especialização com a qual trabalha;

c) a necessidade do trabalho em equipe com outros especialistas;

d) a necessidade de conhecimentos gerenciais e de novas tecnologias;

e) a característica de não trabalhar necessariamente numa unidade informacional denominada biblioteca;

f) a necessidade de conhecer técnicas melhores e mais eficazes de análise e recuperação da informação;

g) a integração da biblioteca e/ou unidade informacional com o sistema especializado e outros sistemas;

h) a necessidade do profissional da área em buscar a educação continuada, tanto a formal, como a informal.

Mueller (1989, p. 63) compreende a expressão perfil profissional como "[...] o conjunto de conhecimentos, qualidades e competências próprias dos integrantes de uma profissão". Esse entendimento, segundo Mueller, está diretamente ligado à ideia da atividade profissional, onde o perfil é traçado a partir das habilidades, competências e atitudes necessárias ao desempenho da função.

A discussão da problemática relacionada ao perfil profissional, de acordo com Mueller (1989), refere-se à discussão da função social da profissão. Diante disso, a autora assinala algumas características que considera relevantes no que concerne ao perfil do bibliotecário:

a) a função da preservação do conhecimento humano;

b) a função do suporte ao estudo e à pesquisa; e

c) o planejamento e a administração de recursos informacionais. 
Nota-se, no trabalho de Mueller, uma certa influência dos estudos franceses acerca de competência profissional, uma vez que relaciona as práticas profissionais do bibliotecário ao contexto organizacional. Nesse sentido, a autora afirma que o perfil profissional deve adaptar-se ao meio e que novas competências e atitudes devem ser desenvolvidas na mesma medida em que emergem novas práticas profissionais.

O profissional da informação é, segundo Mason (1990), o reflexo do contexto sócio-histórico mundial pelo qual a Biblioteconomia e a Ciência da Informação traçaram sua história. O conceito de um profissional holístico, aberto, flexível, criativo, dinâmico e proativo, de acordo com Mason, era cada vez mais enfatizado e discutido, posto que o mercado de trabalho estava em busca constante por profissionais da informação com esse perfil. E, nesse sentido, o autor destaca a importância de as instituições formadoras destes indivíduos preocuparem-se em adequar os currículos dos cursos para formarem profissionais modernos, atentos às especificidades de cada realidade organizacional e capazes de atuar em diversas áreas.

Seguindo semelhante linha de raciocínio, Santos (1996, p. 12), ressaltava que "[...] os bibliotecários brasileiros estão saindo de sua área de domínio, segura e confortável (o documento escrito) e entrando no tratamento específico da informação [...]", ou seja, evoluíram de um paradigma tecnicista a um cenário em que a informação poderia ser organizada sob perspectivas diversas, a depender do contexto em que estava inserida. A autora recomendava que o perfil almejado para o bibliotecário contemporâneo contemplasse, ao menos, os seguintes elementos:

a) habilidades gerenciais;

b) capacidade de comunicação efetiva;

c) habilidades no tratamento interpessoal;

d) habilidades pedagógicas;

e) conhecimentos fundamentais em: teoria da informação, estudos de usuários e comunidades e elementos de pedagogia;

f) conhecimento de línguas estrangeiras, estatística, metodologias de pesquisa e tecnologia da informação. 
No final da década de 1990, Tarapanoff (1999) faz uma análise sobre os desafios em reconhecer as novas demandas e o preparo do bibliotecário e demais profissionais da informação para o exercício de atribuições decorrentes do paradigma da sociedade da informação.

No tocante às novas demandas, de acordo com Tarapanoff (1999), uma solução seria a realização de levantamentos e pesquisas de mercado e o estudo da oferta e procura de perfis específicos de emprego. Já em relação às novas atribuições no contexto da sociedade da informação, a autora argumenta que não há uma definição precisa de quais seriam os papeis do profissional da informação.

Para Tarapanoff (1999, p. 34), existe a necessidade de desenvolvimento de uma identidade profissional situacional, onde o bibliotecário detenha uma visão holística e considere as diferentes perspectivas apresentadas dentro do novo cenário. Segundo a autora,

[...] o novo modelo de carreira segue a natureza mutável do trabalho, e da importância e dinâmica do capital intelectual. Não apenas o capital humano, mas aspectos estruturais e organizacionais, também são essenciais para compreendê-lo. Hoje em vez de trabalho, temos projetos. Um projeto é simplesmente uma tarefa que tem um começo, um escopo definido, e um fim. Diferentemente de departamentos ou processos, os projetos são concebidos, pessoas são contratadas para executá-lo, ele é completado e encerrado. Projetos congregam pessoas com qualificações e formações diversificadas, que se organizam em torno de um problema para resolvê-lo. As forças de tarefa são temporárias e são avaliadas não em termos de posição de chefia, mas de forma flexível, de acordo com a competência.

Tarapanoff (1999) afirma, ainda, que, nesse novo contexto, os indivíduos devem estar preparados para o aprendizado contínuo. A autora sustenta que há a necessidade de aperfeiçoamento profissional constante por parte do bibliotecário, em especial aqueles formados há muito tempo. E adverte que o profissional precisa estar preparado para novas oportunidades e para isso, deve assumir a responsabilidade pela aquisição dos conhecimentos necessários ao desenvolvimento de seu próprio perfil profissional. 
Nessa mesma linha de pensamento, Werthein (2000) defende que a educação continuada e a flexibilidade são atributos que caracterizam a essência do novo paradigma. Para o autor, a flexibilidade fornece respaldo às necessidades de constantes adaptações dos profissionais, frente às sucessivas mudanças no ambiente organizacional, o que institui a exigência de contínuo aperfeiçoamento intelectual e técnico como requisito da sociedade da informação.

Arruda, Marteleto e Souza (2000), realizaram uma pesquisa no intuito de discutir quais as habilidades necessárias e qual seria o perfil adequado ao bibliotecário que o tornasse capaz de interagir como sujeito diante das novas perspectivas no mundo do trabalho. Contudo, os autores verificaram que essa discussão não é exclusiva da área da informação, mas intrínseco aos paradigmas gerais de gestão do trabalho e interação entre os indivíduos. E ponderaram que o perfil do bibliotecário contemporâneo deveria estar em conformidade com as mudanças, delineando-se, dessa forma, um perfil de especialização flexível, que prezasse pela educação continuada e interdisciplinar, integração organizacional e atuação em equipe.

Castro (2000), afirma que o perfil e as atitudes do MIP evidenciam mudanças em relação ao perfil e atividades executadas pelo bibliotecário tradicional. Para demonstrar as transformações ocorridas. Castro apresentou, no quadro 8 , um comparativo entre aspectos dos perfis do tradicional profissional da informação versus o moderno profissional da informação: 
Quadro 8 - Comparação entre os perfis e as atitudes dos tradicionais e dos modernos profissionais da informação.

\begin{tabular}{|c|c|}
\hline $\begin{array}{c}\text { Aspectos do Tradicional Profissional da } \\
\text { Informação }\end{array}$ & $\begin{array}{l}\text { Aspectos do Moderno Profissional da } \\
\text { Informação }\end{array}$ \\
\hline $\begin{array}{l}\text { Demasiada atenção às técnicas } \\
\text { biblioteconômicas. }\end{array}$ & $\begin{array}{l}\text { Atenção às técnicas biblioteconômicas e } \\
\text { documentais. }\end{array}$ \\
\hline Atitudes gerenciais ativas. & Atitudes gerencias proativas. \\
\hline $\begin{array}{l}\text { Desenvolvimento de práticas } \\
\text { profissionais em espaços determinados: } \\
\text { bibliotecas, centos de documentação. }\end{array}$ & $\begin{array}{l}\text { Desenvolvimento de atividades onde haja } \\
\text { necessidade de informação. }\end{array}$ \\
\hline $\begin{array}{l}\text { Tratamento e disseminação de } \\
\text { informação impressa em suportes } \\
\text { tradicionais. }\end{array}$ & $\begin{array}{l}\text { Tratamento e disseminação de } \\
\text { informação, independentemente do seu } \\
\text { suporte físico. }\end{array}$ \\
\hline Espírito crítico e bom senso. & Espírito crítico e bom senso. \\
\hline $\begin{array}{l}\text { Atendimento real ao usuário (relação } \\
\text { sujeito x sujeito). }\end{array}$ & $\begin{array}{l}\text { Atendimento real e virtual ao cliente } \\
\text { (sujeito } \mathrm{x} \text { sujeito, sujeito } \mathrm{x} \text { máquina) }\end{array}$ \\
\hline $\begin{array}{l}\text { Uso tímido das tecnologias de } \\
\text { informação. }\end{array}$ & $\begin{array}{l}\text { Intenso uso das tecnologias da } \\
\text { informação. }\end{array}$ \\
\hline Domínio de línguas estrangeiras. & Domínio de línguas estrangeiras. \\
\hline $\begin{array}{l}\text { Práticas interdisciplinares pouco } \\
\text { representativas. }\end{array}$ & Atividades práticas interdisciplinares. \\
\hline $\begin{array}{l}\text { Pesquisas centradas nas abordagens } \\
\text { quantitativas. }\end{array}$ & $\begin{array}{l}\text { Fusão entre as abordagens qualitativas e } \\
\text { quantitativas. }\end{array}$ \\
\hline $\begin{array}{l}\text { Estudo das necessidades de informação } \\
\text { dos usuários e avaliação de coleções de } \\
\text { bibliotecas. }\end{array}$ & $\begin{array}{l}\text { Estudo das necessidades de informação } \\
\text { dos clientes e avaliação dos recursos dos } \\
\text { sistemas de informação. }\end{array}$ \\
\hline Relação biblioteca e sociedade. & Relação informação e sociedade. \\
\hline $\begin{array}{l}\text { Domínio acentuado nos saberes } \\
\text { biblioteconômicos. }\end{array}$ & $\begin{array}{l}\text { Domínio dos saberes biblioteconômicos e } \\
\text { áreas afins. }\end{array}$ \\
\hline $\begin{array}{l}\text { Planejamento e gerenciamento de } \\
\text { bibliotecas e centros de documentação. }\end{array}$ & $\begin{array}{l}\text { Planejamento e gerenciamento de } \\
\text { sistemas de informação. }\end{array}$ \\
\hline $\begin{array}{l}\text { Preocupação no armazenamento e } \\
\text { conservação das coleções de } \\
\text { documentação e objetos. }\end{array}$ & $\begin{array}{l}\text { Preocupação na análise, comunicação e } \\
\text { uso da informação. }\end{array}$ \\
\hline Educação continuada esporádica. & $\begin{array}{l}\text { Intenso processo de educação } \\
\text { continuada. }\end{array}$ \\
\hline Treinamento em recursos bibliográficos. & Treinamento em recursos informacionais. \\
\hline $\begin{array}{l}\text { Tímida participação em políticas sociais, } \\
\text { educacionais, científicas e tecnológicas. }\end{array}$ & $\begin{array}{l}\text { Ativa participação nas políticas sociais, } \\
\text { educacionais, científicas e tecnológicas. }\end{array}$ \\
\hline
\end{tabular}

Fonte: Castro (2000).

Araújo e Dias (2005) analisaram, em termos práticos, as exigências relativas ao perfil do bibliotecário, no contexto da sociedade da informação, a partir de três aspectos: 
a) função de formação e desenvolvimento de coleções: o bibliotecário deve possuir habilidade para utilizar as tecnologias da informação, pois para o atendimento das novas demandas, o mesmo deveria ser especialista em aquisição, recuperação, mapeamento, seleção, e avaliação da informação em diferentes suportes, além de atuar em ambientes informacionais cooperativos;

b) função de dinamização da informação: essa função está relacionada ao serviço de referência, exigindo para tanto, atualização profissional constante e proatividade por parte do bibliotecário, ou seja, demandava uma postura de constante busca do conhecimento e antecipação às necessidades de informação do usuário;

c) gerenciamento: a atuação profissional nesse contexto exige do bibliotecário uma postura de criatividade, de renovação constante, de busca do conhecimento em contextos multidisciplinares e de predisposição para enfrentar os desafios decorrentes do novo paradigma.

Um estudo comparativo, com a finalidade de identificar o perfil do bibliotecário brasileiro, foi realizado por Almeida \& Baptista (2009) e utilizou, como base de investigação, as teses de Doutorado de Baptista (1998) e Walter (2008), para verificar as principais mudanças longo de dez anos. A análise resultou na seguinte percepção:

a) os estudos atestam que a biblioteconomia é uma profissão predominantemente feminina;

b) no estudo de Baptista (1998), a maioria dos profissionais entrevistados concentrava-se na faixa etária de 30 a 49 anos e 15 anos de formados. Já na pesquisa de Walter (2008) a maioria concentrou-se na faixa de 40 a 59 anos e um grande número de profissionais com menos de 10 anos de formados;

c) em relação ao local de atuação, as duas pesquisas indicaram que a maioria dos bibliotecários desempenha suas atividades em bibliotecas universitárias ou especializadas; 
d) referente à faixa salarial, os estudos apontaram que mais de $60 \%$ dos bibliotecários percebiam renda acima de 7 salários mínimos em 1998 e em 2008 apenas 36,9\% estavam dentro dessa faixa de rendimentos;

e) no quesito educação continuada, em 1998, 59,6\% dos bibliotecários possuíam somente o curso de graduação, 26,8\% tinham cursado algum tipo de pós-graduação lato sensu, 7,9\% cursaram o mestrado e 2,1\% o curso de doutorado. Em 2008, a pesquisa de Walter evidenciou uma evolução em relação à formação acadêmica dos bibliotecários: o percentual de bibliotecários que possuía o curso de especialização lato sensu $(45,1 \%)$ superou o percentual de profissionais que tinham somente a graduação $(43,6 \%)$. Além disso, o quantitativo de mestres e doutores em Biblioteconomia aumentou 10,8\% em relação ao ano de 1998.

Russo (2010) destaca a importância da competência gerencial dentre aquelas que são exigidas do bibliotecário, no contexto da sociedade da informação. A autora enfatiza que o que se espera dos bibliotecários, diante desse cenário, é o gerenciamento eficiente dos recursos disponíveis em seus ambientes de trabalho. E para que essa competência seja desenvolvida e aprimorada, Russo aponta alguns requisitos que considera relevantes:

a) acompanhamento das inovações tecnológicas;

b) aprendizagem em nível multidisciplinar;

c) aprimoramento profissional constante;

d) atitude ética;

e) conhecimentos técnicos e administrativos;

f) engajamento em questões políticas e sociais, principalmente questões relacionadas ao acesso e uso da informação;

g) espírito empreendedor e de liderança;

h) flexibilidade e criatividade no trabalho.

Segundo Cordeiro et al. (2013, p. 73), observa-se o surgimento de mais um novo paradigma, denominado "o quarto paradigma". Conforme os autores, esse novo cenário configura-se pela "[...] exploração de grandes quantidades de 
dados, que unifica teoria, experimentos e simulação, ao mesmo tempo em que lida com uma quantidade enorme de informação". Segundo os autores, em decorrência das mudanças trazidas pelo quarto paradigma surgiu um novo modelo de metodologia científica: a e-science (ou e-ciência).

A e-science, de acordo com Costa e Cunha (2014), também é caracterizada pela geração um grande volume de dados, contudo, esses dados são obtidos em âmbito científico.

Diante dessa nova conjuntura, Costa e Cunha (2014), abordam, em seu estudo, sobre o papel do bibliotecário no contexto do quarto paradigma. Os autores salientam a necessidade de um novo perfil de profissional, que esteja apto para atuar em ambiente virtual e preservar informações digitais. Salientam, ainda, a conveniência de um profissional com habilidades multidisciplinares e visão holística, para o tratamento dos dados da e-science. 


\section{O AMBIENTE DA PESQUISA}

\subsection{BREVE HISTÓRICO DA INSTITUIÇÃO}

O Instituto Federal de Educação, Ciência e Tecnologia de Brasília (IFB) foi criado pela Lei no 11.892, de 2008, compreendendo uma instituição de educação superior, básica e profissional, pluricurricular e multicampi. Tem como foco a oferta de educação profissional e tecnológica nas diferentes modalidades de ensino (BRASIL. MINISTÉRIO DA EDUCAÇÃO, 2014b).

A implantação e o desenvolvimento da Instituição têm suas origens na criação da Escola Técnica de Brasília, no ano de 1959, por meio do Plano de Metas do Governo do Presidente Juscelino Kubitschek e em 1962 recebeu o nome de Escola Agrotécnica de Brasília, subordinada à Superintendência do Ensino Agrícola e Veterinário do Ministério da Agricultura. Em 1964, passou a identificar-se como Colégio Agrícola de Aplicação de Brasília. Em 1967, foi incorporado ao Ministério de Educação e da Cultura e voltou a chamar-se Colégio Agrícola de Brasília (BRASIL. MINISTÉRIO DA EDUCAÇÃO, 2014b).

No ano de 1978 o Colégio Agrícola de Brasília foi transferido para o Governo do Distrito Federal (GDF) e vinculou-se à Rede de Ensino Oficial do Distrito Federal, com a mesma denominação. Em 2007, por intermédio da Lei no 11.534, de 2007, passa a chamar-se Escola Técnica Federal, conferindo status de autarquia e vinculada ao Ministério da Educação. Um ano após, foi criado o Instituto Federal de Educação, Ciência e Tecnologia de Brasília (IFB) e, diferentemente dos outros Institutos Federais Brasileiros, que surgiram a partir da transformação dos antigos Centros Federais de Educação Tecnológica (CEFETs), - IFB surgiu a partir da transformação da então Escola Técnica Federal de Brasília, pela Lei no 11.892, de 2008 e passou a fazer parte da Rede Federal de Educação Profissional, Científica e Tecnológica.

Constituído inicialmente por apenas um campus (campus Planaltina), em 2015, o IFB possuía 10 campi em funcionamento (campi: Brasília, Ceilândia, Estrutural, Gama, Planaltina, Samambaia, Riacho Fundo, Taguatinga, Taguatinga Centro e São Sebastião) desenvolvendo atividades de ensino, pesquisa e 
extensão, de acordo com as Políticas e Diretrizes do Ministério da Educação (MEC) (BRASIL. MINISTÉRIO DA EDUCAÇÃO, 2014b).

\subsection{OBJETIVOS INSTITUCIONAIS}

Constituem características e objetivos do Instituto Federal de Educação, Ciência e Tecnologia de Brasília (IFB), de acordo com a Lei nํ 11.892, de 2008:

a) ofertar educação profissional e tecnológica, em todos os seus níveis e modalidades, formando e qualificando cidadãos com vistas na atuação profissional nos diversos setores da economia, com ênfase no desenvolvimento socioeconômico local, regional e nacional;

b) desenvolver a educação profissional e tecnológica como processo educativo e investigativo de geração e adaptação de soluções técnicas e tecnológicas às demandas sociais e peculiaridades regionais;

c) promover a integração e a verticalização da educação básica à educação profissional e educação superior, otimizando a infraestrutura física, os quadros de pessoal e os recursos de gestão;

d) orientar sua oferta formativa em benefício da consolidação e fortalecimento dos arranjos produtivos, sociais e culturais locais, identificados com base no mapeamento das potencialidades de desenvolvimento socioeconômico e cultural no âmbito de atuação do Instituto Federal;

e) constituir-se em centro de excelência na oferta do ensino de ciências, em geral, e de ciências aplicadas, em particular, estimulando o desenvolvimento de espírito crítico, voltado à investigação empírica;

f) qualificar-se como centro de referência no apoio à oferta do ensino de ciências nas instituições públicas de ensino, oferecendo capacitação técnica e atualização pedagógica aos docentes das redes públicas de ensino;

g) desenvolver programas de extensão e de divulgação científica e tecnológica;

h) realizar e estimular a pesquisa aplicada, a produção cultural, o empreendedorismo, o cooperativismo e o desenvolvimento científico e tecnológico; 
i) promover a produção, o desenvolvimento e a transferência de tecnologias sociais, notadamente as voltadas à preservação do meio ambiente.

\subsection{MISSÃO, VISÃO E VALORES}

Constitui missão do IFB (BRASIL. MINISTÉRIO DA EDUCAÇÃO, 2014b, p.15):

\footnotetext{
Oferecer ensino, pesquisa e extensão no âmbito da Educação Profissional e Tecnológica, por meio da inovação, produção e difusão de conhecimentos, contribuindo para a formação cidadã e $\quad$ desenvolvimento sustentável, comprometidos com a dignidade humana e a justiça social.
}

De acordo com o Plano de Desenvolvimento Institucional - PDI (BRASIL. MINISTÉRIO DA EDUCAÇÃO, 2014b, p.16) da instituição, o IFB pretende "[...] até 2018, consolidar-se no Distrito Federal como instituição pública de Educação Profissional e Tecnológica de qualidade inclusiva e emancipatória, articulada em rede e com a comunidade".

A instituição possui como valores (BRASIL. MINISTÉRIO DA EDUCAÇÃO, 2014b):
a) ética;
b) educação como bem público gratuito e de qualidade;
c) formação crítica, emancipatória e cidadã;
d) gestão democrática: transparência, participação, autonomia, pluralismo e integração;
e) respeito à diversidade e à dignidade humana;
f) promoção da inclusão;
g) inovação;
h) sustentabilidade econômica e socioambiental. 


\subsection{O SISTEMA DE BIBLIOTECAS DO INSTITUTO FEDERAL DE EDUCAÇÃO, CIÊNCIA E TECNOLOGIA DE BRASÍLIA - SIBIFB}

O Sistema de Bibliotecas do IFB (SIBIFB), criado em 2008, é composto uma unidade de coordenação geral, localizada na Reitoria da Instituição, situada na cidade de Brasília e por oito bibliotecas setoriais, localizadas nos seguintes campi: Brasília, Gama, Planaltina, Samambaia, Riacho Fundo, Taguatinga, Taguatinga Centro e São Sebastião. Atua como centro de informação e referência, oferecendo suporte informacional aos programas de ensino, pesquisa e extensão do IFB. Sua estrutura gerencial é composta por uma coordenação geral do sistema e uma coordenação de biblioteca em cada campus. As bibliotecas setoriais funcionam de maneira descentralizada, porém oferecem serviços padronizados e integrados ao SIBIFB (BRASIL. MINISTÉRIO DA EDUCAÇÃO, 2014c).

A atualização e a ampliação do acervo são regulamentadas pelas diretrizes da Política de Desenvolvimento de Coleções (PDC) e elaborada pelo Sistema de Bibliotecas do Instituto Federal de Brasília (SIBIFB). Para tanto, leva em consideração, no processo de formação e desenvolvimento das coleções, os componentes curriculares dos cursos oferecidos pelo IFB, conforme as recomendações do MEC, para determinar as quantidades de exemplares, bibliografia básica e complementar de cada modalidade de curso e, também, por meio das sugestões da comunidade acadêmica encaminhadas à Biblioteca e avaliadas pela equipe técnica (BRASIL. MINISTÉRIO DA EDUCAÇÃO, 2014b).

A estrutura das bibliotecas possui capacidade para acomodar em torno de 20.000 itens, sendo que, segundo dados de 2014, essas bibliotecas possuíam, em média, 2.900 itens, com projeção de crescimento de cerca de 10\% ao ano. (BRASIL. MINISTÉRIO DA EDUCAÇÃO, 2014b).

\subsubsection{Atribuições das Coordenações de Biblioteca do IFB}

São atribuições das coordenações de biblioteca (BRASIL. MINISTÉRIO DA EDUCAÇÃO, 2014c):

a) atender a comunidade acadêmica e o público em geral, prestando serviços informacionais e bibliográficos que contribuam ao 
desenvolvimento dos programas de ensino, pesquisa e extensão do IFB e para a socialização da cultura;

b) suprir a comunidade acadêmica com metodologias, informações e serviços para a produção, disseminação e uso da informação disponível no acervo e em outras fontes e instituições;

c) propor políticas institucionais de informação bibliográfica e técnica, e de serviços biblioteconômicos;

d) avaliar, periodicamente, as bibliotecas enquanto setor fundamental de apoio pedagógico da Instituição e providenciar as ações corretivas que se fizerem necessárias;

e) selecionar, adquirir, organizar, divulgar e manter atualizado o acervo informacional em consonância com a Política de Desenvolvimento de Coleções;

f) acompanhar o processo de compra de livros, assinatura e renovação de periódicos;

g) gerenciar e controlar o intercâmbio e a doação de livros, periódicos e outros documentos;

h) realizar o inventário dos materiais bibliográficos;

i) estabelecer parcerias com bibliotecas e entidades de interesse comum ao das áreas de atuação dos campi, com vistas ao intercâmbio de informações e desenvolvimento de projetos;

j) preservar e organizar a memória institucional, de acordo com a Política de Desenvolvimento de Coleções do IFB;

k) proporcionar instrumentos adequados de avaliação dos serviços prestados pelas bibliotecas;

I) promover a divulgação e o reconhecimento dos serviços das bibliotecas por meio de estratégias de marketing.

\subsubsection{Atribuições dos Bibliotecários que Atuam no IFB}

A carreira de bibliotecário do IFB é regida por meio da Lei Federal oㅡ 11.091, de 12 de janeiro de 2005 e suas atribuições constam na Resolução no 007-2013-CS/IFB. 
São atribuições inerentes ao cargo de bibliotecário do Instituto Federal de Educação, Ciência e Tecnologia de Brasília (BRASIL. MINISTÉRIO DA EDUCAÇÃO, 2013):

1. disponibilizar informação através da localização e recuperação de informações;

2. prestar atendimento personalizado e serviços de informação on-line;

3. elaborar estratégias de buscas avançadas;

4. controlar a circulação de recursos informacionais;

5. gerenciar recursos de informação e elaborar políticas de funcionamento para a biblioteca, programas e projetos de ação, manuais de serviços, procedimentos e relatórios;

6. implementar atividades cooperativas entre instituições;

7. administrar o compartilhamento de recursos informacionais;

8. desenvolver políticas de informação e padrões de qualidade gerencial e implementar padrões de qualidade;

9. automatizar unidades de informação;

10. coordenar a execução dos planos de atividades do setor;

11. avaliar e implementar serviços e produtos da biblioteca;

12. desenvolver e executar planos de conservação, restauração e proteção do patrimônio da biblioteca;

13.tratar tecnicamente recursos informacionais;

14. auxiliar na seleção e na aquisição de documentos para incorporação ao acervo;

15. tombar, registrar, classificar e catalogar recursos informacionais;

16. elaborar linguagens documentárias;

17. desenvolver e gerenciar bases de dados bibliográficos;

18. gerenciar qualidade e conteúdo de fontes de informação;

19. gerar fontes de informação;

20.desenvolver metodologias para geração de documentos digitais ou eletrônicos;

21.assessorar o desenvolvimento de interfaces de serviços informatizados; 
22. descartar recursos informacionais;

23. coordenar e desenvolver bibliotecas virtuais e digitais;

24. disseminar informação;

25. desenvolver estudos e pesquisas referentes a recursos de informação e implementação dos mesmos;

26. prestar serviços de assessoria e consultoria dando assistência técnica às bibliotecas das unidades do IFB;

27. realizar difusão cultural promovendo atividades de fomento à leitura;

28. desenvolver ações educativas elaborando serviços de apoio para educação presencial e à distância;

29. assessorar as atividades de ensino, pesquisa e extensão na sua área de atuação.

\subsubsection{Serviços Oferecidos pelo Sistema de Bibliotecas - SIBIFB}

As bibliotecas do IFB oferecem os seguintes serviços aos usuários (BRASIL. MINISTÉRIO DA EDUCAÇÃO, 2014c):
a) acesso à internet;
b) comutação bibliográfica;
c) disponibilização de livros eletrônicos;
d) disseminação seletiva da informação (DSI);
e) empréstimo domiciliar;
f) empréstimo entre bibliotecas;
g) levantamento bibliográfico;
h) orientação quanto à normalização de trabalhos acadêmicos;
i) pesquisa em bases de dados;
j) pesquisa on-line ao acervo;
k) renovação de material bibliográfico;
l) reserva de material bibliográfico;
m) treinamento de usuários para o uso de bases de dados;
n) visitas orientadas à biblioteca. 


\section{PROCEDIMENTOS METODOLÓGICOS}

Esta pesquisa tipifica-se como um estudo de caso, consoante à definição dessa metodologia por Ventura (2007, p.384):

[...] o estudo de caso como modalidade de pesquisa é entendido como uma metodologia ou como a escolha de um objeto de estudo definido pelo interesse em casos individuais. Visa à investigação de um caso específico, bem delimitado, contextualizado em tempo e lugar para que se possa realizar uma busca circunstanciada de informações.

Ainda no tocante aos aspectos metodológicos, o estudo possui caráter quanti-qualitativo, com abordagem descritiva. Conforme explicam Silveira \& Córdona (2009, p. 33) "[...] a pesquisa quantitativa, que tem suas raízes no pensamento positivista lógico, tende a enfatizar o raciocínio dedutivo, as regras da lógica e os atributos mensuráveis da experiência humana".

Para a análise qualitativa, utilizou-se a técnica de Discurso do Sujeito Coletivo (DSC), criada por Lefèvre e Lefèvre (2003). A técnica consiste em esquemas de observação e análise, aplicadas à coleta de manifestações verbais e/ou escritas dos indivíduos entrevistados, classificadas em expressões-chave, ideias centrais e ancoragem e que, ao final, são condensadas em um único discurso da realidade coletiva.

Como o problema de pesquisa foi definido como o mapeamento de competências, foram utilizados, como base de referência, os procedimentos e metodologias desenvolvidos por Brandão e Bahry (2005), Carbone et al. (2006) e por Ruzzarin e Simionovschi (2010). Para as competências dos bibliotecários, utilizou-se, como principal parâmetro, o resultado do estudo desenvolvido no IV Encuentro de Directores de Escuelas de Bibliotecología y Ciencia de La Información del Mercosur, citado por Valentim, 2000.

Considera-se que a função substancial da base de referência é propiciar informações consistentes à elaboração do instrumento de pesquisa para o mapeamento de competências e identificação do perfil do profissional. $O$ referencial adotado permitiu, outrossim, a delimitação das variáveis do mapeamento, apontando o conjunto de atributos necessários ao estudo. 
Realizou-se também, como forma de orientação para o desenvolvimento do estudo, uma pesquisa documental, referente às estratégias, planos e atribuições organizacionais. Nesta etapa, foi feita a leitura dos documentos pertinentes à estrutura do Instituto Federal de Educação, Ciência e Tecnologia de Brasília, observando-se aspectos como: organograma, visão, missão, valores, plano de desenvolvimento institucional e plano de carreira dos servidores da Instituição. Verificou-se, ainda, a documentação referente às atribuições e responsabilidades inerentes aos bibliotecários da instituição, no intuito de subsidiar o desenvolvimento do instrumento de pesquisa.

\subsection{UNIVERSO DA PESQUISA}

O universo da presente pesquisa corresponde aos bibliotecários, pertencentes ao quadro efetivo de servidores do Instituto Federal de Educação, Ciência e Tecnologia da Brasília (IFB) e atuantes nas oito bibliotecas da instituição (total de 19 indivíduos), localizadas nos seguintes campi: Brasília, Gama, Planaltina, Samambaia, Riacho Fundo, Taguatinga, Taguatinga Centro e São Sebastião.

A escolha da instituição para o estudo de caso (Instituto Federal de Educação, Ciência e Tecnologia de Brasília, IFB) foi intencional. Para essa seleção levou-se em consideração:

a) a localização central dessa instituição no território brasileiro;

b) é a única instituição que atua no segmento de ensino profissional e tecnológico, em âmbito Federal, no Distrito Federal;

c) a estrutura organizacional, por possuir o modelo padrão adotado para toda a rede nacional de Ensino Profissional e Tecnológico;

d) a estrutura das bibliotecas, tendo em vista que a instituição dispõe de um Sistema de Bibliotecas integrado e consolidado.

\subsection{COLETA DE DADOS}

A proposta inicial do estudo foi realizar um censo, posto que pretendeu-se coletar dados e informações de todos os indivíduos referentes ao universo da pesquisa. 
O instrumento utilizado, inicialmente, na coleta de dados foi um questionário semi-estruturado, enviado e respondido em meio eletrônico. Foram incluídas perguntas fechadas, utilizando-se da escala Likert, que, de acordo com Carbone et al. (2006, p.63), permite avaliar "[...] o grau de importância das competências relacionadas [...]", questões onde haveria a possibilidade de o respondente escolher apenas uma alternativa dentre uma lista pré-definida, e questões mistas, que incluíam assertivas abertas e fechadas.

Algumas perguntas abertas, onde 0 indivíduo podia responder às perguntas de maneira livre, também foram incluídas, no intuito de possibilitar ao respondente $\mathrm{o}$ acréscimo de informações que considerava importantes à pesquisa e que não estavam disponíveis dentre as assertivas que compunham o questionário. O questionário, ainda segundo Carbone et al. (2006, p.62)

[...] talvez seja a técnica de pesquisa mais utilizada para realizar o mapeamento de competências relevantes a determinado contexto ou estratégia organizacional. A formatação desse instrumento de pesquisa geralmente exige a aplicação prévia de uma ou mais técnicas (análise documental, observação e entrevista), com o objetivo de identificar elementos para compor os itens do questionário.

Após a aplicação do questionário e tratamento dos dados coletados, utilizou-se do mesmo questionário, acrescido de cinco perguntas abertas, para entrevistar os bibliotecários, com o objetivo de obter informações mais detalhadas acerca das questões apresentadas.

O instrumento de coleta de dados foi elaborado a partir da revisão de literatura sobre perfil e competências dos bibliotecários, ficando subdividido em dois blocos. O primeiro bloco (questões de № 1 a 15) constituiu-se de perguntas direcionadas à identificação do perfil dos bibliotecários, no intuito de atender ao terceiro objetivo específico desta pesquisa, isto é, identificar o perfil do bibliotecário que atua na Rede Federal de Educação Profissional e Tecnológica do Distrito Federal. Para esta etapa, foram utilizadas as seguintes variáveis:
a) sexo;
b) faixa etária;
c) tempo de formado em Biblioteconomia; 
d) tempo de atuação como bibliotecário;

e) tempo de atuação na instituição;

f) cursos de capacitação profissional e fatores de influência para atuar no segmento de educação profissional e tecnológica.

O segundo bloco (questões de № 16 a 20) visava mapear as competências que os bibliotecários possuem e julgam necessárias ao desenvolvimento do trabalho, no contexto da Rede Federal de Educação Profissional e Tecnológica do Distrito Federal, com a finalidade de atender ao propósito estabelecido no primeiro objetivo específico deste estudo, ou seja, mapear as competências necessárias ao desenvolvimento das atividades profissionais, segundo a percepção dos bibliotecários que atuam na Rede Federal de Educação Profissional e Tecnológica do Distrito Federal. Nesta fase, as variáveis foram divididas em quatro grandes áreas:

a) competências em comunicação e expressão: capacidade de orientar os usuários para um melhor uso dos recursos de informação, capacidade de comunicação e interação com os usuários da informação, capacidade de comunicação e interação com os demais servidores da biblioteca, capacidade de disseminação da informação e capacidade de disseminação de produtos e serviços oferecidos pela biblioteca;

b) competências técnico-científicas: capacidade de desenvolver e executar o processamento de documentos em distintos suportes, capacidade de selecionar e difundir a informação gravada em qualquer meio para os usuários, capacidade de elaborar produtos de informação, capacidade de utilizar e disseminar fontes, produtos e recursos de informação em diferentes suportes, capacidade de formular políticas de pesquisa em Biblioteconomia e Ciência da Informação, capacidade de pesquisa e domínio das diversas fontes de informação, capacidade de utilizar recursos da Tecnologia da Informação, capacidade de utilizar recursos de acessibilidade e capacidade de utilizar recursos de educação à distância; 
c) competências gerenciais: capacidade de gerenciar unidades, sistemas e serviços de informação, capacidade de gerenciar projetos de gestão da informação, capacidade de aplicar técnicas de marketing, de liderança e de relações públicas, capacidade de planejar e gerenciar recursos econômico-financeiros e humanos, capacidade de planejar, coordenar e avaliar a preservação e conservação documental, capacidade de planejar e desenvolver estudos de usuários da informação e capacidade de gerenciar redes colaborativas de informação;

d) competências sociais e políticas: capacidade de formular políticas de informação em educação, capacidade de fomentar a interação entre a biblioteca e os diversos tipos de usuários, capacidade de identificar demandas sociais de informação, capacidade de atuar para promover a profissão, capacidade de promover ações de incentivo à leitura e à pesquisa científica e capacidade de promover a inclusão social.

\subsection{PRÉ-TESTE}

Após a elaboração do instrumento de coleta de dados foi aplicado um teste piloto, para verificar a aplicabilidade do questionário ao tema de pesquisa proposto e compreensão das assertivas pelos bibliotecários. De acordo com Carbone et al. (2006, p.63) "[...] é fundamental realizar uma validação semântica do questionário antes de sua aplicação, [...] visando verificar se o enunciado, a escala e os itens do instrumento são inteligíveis aos respondentes".

O pré-teste foi realizado no mês de julho de 2014, com os bibliotecários que atuam no Instituto Federal de Educação, Ciência e Tecnologia de Goiás (IFG), totalizando 24 indivíduos. A escolha desses profissionais justifica-se pelo fato de que tanto a instituição quanto as atribuições dos bibliotecários possuem características semelhantes àquelas alusivas ao objeto deste estudo.

Foram aplicados 24 questionários, por meio de formulário eletrônico, disponibilizado via internet. Obteve-se um retorno de 12 questionários (50\%). Utilizou-se, para a elaboração do pré-teste, as mesmas perguntas e variáveis apresentadas no item 4.2, porém com algumas adaptações, considerando-se as 
características peculiares do IFG: número de bibliotecários atuantes na instituição, número de bibliotecas e tempo de criação desse Instituto.

A partir do resultado do teste piloto foi possível ratificar a pertinência do questionário ao tema proposto. Contudo, alguns ajustes referentes à redação das perguntas foram feitos após a coleta e interpretação dos dados, no intento de adaptar as questões à realidade dos bibliotecários que atuam no IFB, considerando as diferenças em relação ao quantitativo de bibliotecários, número de campi e bibliotecas, além do tempo de existência da Instituição, tendo em vista que o IFB surgiu, de fato, a partir da instituição da Lei 11.892/2008 e o IFG apesar de ter sido instituído pela mesma lei, surgiu mediante a transformação do Centro Federal de Educação Tecnológica de Goiás em Instituto Federal de Goiás (Brasil, 2008). 


\section{ANÁLISE DOS DADOS COLETADOS}

Este capítulo exibe os resultados da pesquisa, obtidos, incialmente, por meio da aplicação de questionários eletrônicos, que foram enviados por meio de links de acesso aos bibliotecários que atuam no Instituto Federal de Brasília (IFB) e ficaram disponíveis durante todo o mês de abril de 2015. Após esse período, foi feito um novo contato com os bibliotecários, já que, durante o período de acesso ao questionário, houve o retorno de apenas $50 \%$ destes. Após essa segunda solicitação, o questionário foi enviado novamente aos respondentes, permanecendo acessível até o dia 15 de maio de 2015.

Do total de 19 e-mails enviados aos bibliotecários que atuam nas oito bibliotecas do IFB e coordenação geral das bibliotecas, retornaram 14 questionários $(73,68 \%)$. Os resultados estão dispostos na sequência em que foram apresentados no questionário.

Após a aplicação do questionário, foram realizadas entrevistas com os bibliotecários, no intuito de complementar os dados que já haviam sido coletados e esclarecer algumas questões referentes aos resultados obtidos por esse instrumento de pesquisa. Para tanto, foram elaboradas e utilizadas na entrevista cinco perguntas (conforme o Apêndice 2), além daquelas já constantes do questionário.

As entrevistas foram feitas pessoalmente, durante a última semana do mês de junho de 2015, com 3 bibliotecários (identificados como bibliotecários 8, 9 e 10) e, online, no mesmo período, por meio de aplicativo do Google, com 7 bibliotecários (identificados pela sequência de números de 1 a 7 ), perfazendo um total de $52 \%$ do total de bibliotecários atuantes no IFB. Salienta-se que todos os bibliotecários entrevistados já haviam respondido ao questionário antes da entrevista. 


\subsection{TRATAMENTO DOS DADOS}

Para a tabulação dos dados coletados foi utilizada a técnica de contagem simples de frequência de cada categoria de questões e a técnica de DSC, descrita anteriormente, no item 4.

A análise estatística foi realizada com 0 auxílio das ferramentas disponíveis no aplicativo Microsoft Office Excel 2013. Os resultados dessa análise foram organizados em tabelas que apresentam o questionamento feito, 0 quantitativo de respondentes (representados por "n") para cada item e os percentuais correspondentes (representados por "\%").

\subsection{APRESENTAÇÃO E ANÁLISE DOS RESULTADOS}

O primeiro bloco (tabelas 1 a 12) retrata o perfil dos respondentes. Já o segundo bloco (tabelas 13 a 16) apresenta as competências que os mesmos julgam necessárias para exercer suas atribuições na Instituição, de acordo com as variáveis relacionadas no capítulo 4 , item 4.2.

\subsubsection{Perfil dos Bibliotecários}

As tabelas de números 1 a 13 apresentam os resultados que denotam o perfil dos bibliotecários que atuam na Rede Federal de Ensino do Distrito Federal.

A tabela 1 indica o tempo de atuação do bibliotecário, no Instituto Federal de Brasília. Os resultados mostram que 50\% dos bibliotecários iniciaram sua carreira no IFB entre dois e quatro anos, 29\% ingressaram há até um ano e 21\% entre cinco e sete anos. Esse resultado revela que o quantitativo de bibliotecários que atuam no IFB, desde a sua criação em 2008, até o corrente ano (2015) aumentou quase cinco vezes. Isso evidencia a evolução da contratação dos bibliotecários de acordo com a expansão da Rede, visto que, em 2008, o IFB possuía um campus e uma biblioteca em seu organograma e, em 2015, possui 10 campi e oito bibliotecas. (BRASIL. MINISTÉRIO DA EDUCAÇÃO, 2014b). 
Tabela 1 - Tempo de atuação do bibliotecário no IFB.

\begin{tabular}{c|r|r}
\hline Tempo de & \multicolumn{2}{|c}{ Respondentes } \\
\cline { 2 - 3 } Atuação no IFB & \multicolumn{1}{|c|}{$\mathbf{n}$} & \multicolumn{1}{c}{$\%$} \\
\hline 0 a 1 ano & 4 & $29 \%$ \\
\hline 2 a 4 anos & 7 & $50 \%$ \\
\hline 5 a 7 anos & 3 & $21 \%$ \\
\hline Total & $\mathbf{1 4}$ & $\mathbf{1 0 0 \%}$ \\
\hline
\end{tabular}

Fonte: a autora.

Em relação ao tempo de conclusão do curso de Biblioteconomia, observase, de acordo com a tabela 2 , que $43 \%$ dos respondentes concluíram o curso entre os anos de 2007 e 2009, 29\% entre 2010 e 2012, 21\% entre os anos de 2004 e 2006 e 7\% são recém-formados (concluíram o curso entre os anos de 2013 e 2015). Deste modo, pode-se concluir que o conjunto dos bibliotecários do IFB concluiu a graduação em Biblioteconomia há 11 anos ou menos, sendo que a maioria (72\%) possui entre três e oito anos de formado.

Tabela 2 - Tempo de formado em Biblioteconomia.

\begin{tabular}{c|r|r}
\hline Tempo de & \multicolumn{2}{|c}{ Respondentes } \\
\cline { 2 - 3 } $\begin{array}{c}\text { Formado em } \\
\text { Biblioteconomia }\end{array}$ & $\mathbf{n}$ & \multicolumn{1}{|c}{$\%$} \\
\hline 0 a 2 anos & 1 & $\mathbf{7 \%}$ \\
\hline 3 a 5 anos & 4 & $29 \%$ \\
\hline 6 a 8 anos & 6 & $43 \%$ \\
\hline 9 a 11 anos & 3 & $21 \%$ \\
\hline 12 anos ou mais & 0 & $0 \%$ \\
\hline Total & $\mathbf{1 4}$ & $\mathbf{1 0 0 \%}$ \\
\hline
\end{tabular}

Fonte: a autora.

Verifica-se, conforme apresentado na tabela 3, que a maioria dos respondentes (57\%) possui tempo de atuação como bibliotecário entre seis e oito anos, $29 \%$ entre três e cinco anos, $7 \%$ entre 9 e 11 anos e $7 \%$ há dois anos ou menos. 
Tabela 3 - Tempo de atuação como bibliotecário.

\begin{tabular}{c|r|r}
\hline Tempo de & \multicolumn{2}{|c}{ Respondentes } \\
\cline { 2 - 3 } $\begin{array}{c}\text { Atuação como } \\
\text { Bibliotecário }\end{array}$ & \multicolumn{1}{|c|}{$\mathbf{n}$} & \multicolumn{1}{|c}{$\%$} \\
\hline 0 a 2 anos & 1 & $\mathbf{7 \%}$ \\
\hline 3 a 5 anos & 4 & $\mathbf{2 9 \%}$ \\
\hline 6 a 8 anos & 8 & $57 \%$ \\
\hline 9 a 11 anos & 1 & $7 \%$ \\
\hline 12 anos ou mais & 0 & $0 \%$ \\
\hline Total & $\mathbf{1 4}$ & $\mathbf{1 0 0 \%}$ \\
\hline
\end{tabular}

Fonte: a autora.

Ao estabelecer um comparativo entre os resultados obtidos nas tabelas 2 e 3 percebe-se que, nas categorias "0 a 2 anos" e "3 a 5 anos", o tempo de formado em Biblioteconomia e o tempo de atuação como bibliotecário, possuem percentuais equivalentes. Isto posto, pressupõe-se que os bibliotecários do IFB, formados entre os anos de 2010 e 2015 (36\%), provavelmente, foram inseridos no mercado de trabalho logo após a conclusão do curso e, considerando que $50 \%$ dos respondentes atuam no IFB entre 2 e 4 anos, supõe-se que uma parcela (possivelmente os 36\%) teve sua primeira experiência profissional na Rede Federal de Ensino do Distrito Federal e/ou possuem pouca ou nenhuma experiência em outra instituição.

Algumas inferências relevantes podem ser obtidas ao confrontar os dados obtidos na tabela 2 (tempo de formado em biblioteconomia) com os resultados obtidos na tabela 3 (tempo de atuação como bibliotecário). Observa-se, na tabela 2, que $21 \%$ dos respondentes afirmam que possuem entre 9 e 11 anos de formados, mas, de acordo com a tabela 3, apenas 7\% possuem o mesmo tempo de atuação profissional, ou seja, possivelmente, 14\% dos bibliotecários do IFB não exerceram a profissão logo após a conclusão do curso de Biblioteconomia.

Contudo, o que se verificou, a partir dos resultados obtidos por meio da entrevista, foi que, pelo menos $53 \%$ dos bibliotecários possuíam experiência anterior sendo que $46 \%$ atuaram como bibliotecário em instituições de ensino (16\% atuaram em Institutos Federais de Educação, Ciência e Tecnologia no 
estado de Goiás e 30\% em Universidades) e 7\% trabalharam em outros segmentos.

Cotejando ainda os resultados obtidos nessa pesquisa com a amostra da pesquisa realizada por Baptista (1998), que apontou, à época, que a maioria dos bibliotecários brasileiros em atividade, possuía cerca de 15 anos de formados e a pesquisa de Walter (2008) que constatou que essa média havia diminuído para 10 anos de formados, o presente estudo revela que, no segmento avaliado, essa média diminuiu ainda mais após 7 anos, onde o tempo de conclusão de curso dos bibliotecários situou-se entre 6 a 8 anos.

A tabela 4 denota que a maioria dos bibliotecários atuantes no IFB (57\%) tem idade entre 30 e 35 anos e o restante (43\%) está na faixa etária de 24 a 29 anos. Cabe ressaltar que, de acordo com a pesquisa realizada, não há, na instituição, bibliotecários com idade menor que 23 anos ou maior que 36 anos, isto é, $100 \%$ dos respondentes encontram-se na faixa etária compreendida entre 24 e 35 anos de idade, ou seja, em relação ao quadro efetivo de bibliotecários, a rede federal de ensino do Distrito Federa possui uma força de trabalho jovem.

Tabela 4 - Faixa etária.

\begin{tabular}{r|r|r}
\hline \multirow{2}{*}{ Faixa Etária } & \multicolumn{2}{|c}{ Respondentes } \\
\cline { 2 - 3 } & $\mathbf{n}$ & \multicolumn{1}{c}{$\%$} \\
\hline 18 a 23 anos & 0 & $0 \%$ \\
\hline 24 a 29 anos & 6 & $43 \%$ \\
\hline 30 a 35 anos & 8 & $57 \%$ \\
\hline 36 a 40 anos & 0 & $0 \%$ \\
\hline Acima de 40 anos & 0 & $0 \%$ \\
\hline Total & $\mathbf{1 4}$ & $\mathbf{1 0 0 \%}$ \\
\hline
\end{tabular}

Fonte: a autora.

O resultado apresentado demonstra, em relação ao universo pesquisado, uma mudança em relação à faixa etária, comparando-se com pesquisas anteriores sobre o perfil do bibliotecário brasileiro. Na pesquisa realizada por Baptista (1998), a maioria dos bibliotecários brasileiros, em atividade, possuía entre 30 e 49 anos de idade. Já na pesquisa de Walter (2008) essa média concentrava-se entre 40 e 59 anos de idade. Denota-se, portanto, ao comparar a 
presente pesquisa àquelas realizadas por Baptista e Walter, uma redução na faixa etária compreendida entre 14 e 24 anos.

De acordo com a tabela 5, o corpo de bibliotecários do IFB é composto, em sua grande maioria (79\%), por integrantes do sexo feminino.

Tabela 5 - Sexo.

\begin{tabular}{r|r|r}
\hline \multirow{2}{*}{ Sexo } & \multicolumn{2}{|c}{ Respondentes } \\
\cline { 2 - 3 } & \multicolumn{1}{|c|}{$\mathbf{n}$} & \multicolumn{1}{c}{$\%$} \\
\hline Masculino & 3 & $21 \%$ \\
\hline Feminino & 11 & $79 \%$ \\
\hline Total & $\mathbf{1 4}$ & $\mathbf{1 0 0 \%}$ \\
\hline
\end{tabular}

Fonte: a autora.

Confrontando este resultado com a pesquisa de Baptista (1998), onde 94\% dos bibliotecários eram do sexo feminino e com o estudo de Walter (2008) em que esse percentual diminuiu para $88 \%$, verifica-se que, no presente estudo, essa porcentagem é ainda menor (79\%).

Essa redução no percentual de bibliotecárias nas organizações, já era considerada uma tendência em estudos de gênero, conforme apontava a pesquisa de Ferreira (2003). Embora a autora reconhecesse a profissão como tradicionalmente feminina, ela admitia o aumento de discentes do sexo masculino nos cursos de biblioteconomia.

Segundo Ferreira (2003), na década de 1980, o curso de biblioteconomia tinha a proporção de 1 homem para cada 100 mulheres (1\%), já no início do século $\mathrm{XXI}$, a média era de 5 homens para cada 100 mulheres $(5 \%)$.

Referente ao quesito "Formação Complementar", nota-se, conforme o exposto na tabela 6 , que a maioria dos bibliotecários possui pós-graduação lato sensu (65\%), 14\% cursaram uma segunda graduação e 7\% possuem, além da segunda graduação, curso de especialização e 7\% detém o título de mestre. 
Tabela 6 - Formação complementar.

\begin{tabular}{l|r|r}
\hline \multicolumn{1}{c|}{$\begin{array}{c}\text { Formação } \\
\text { Complementar }\end{array}$} & \multicolumn{2}{|c}{ Respondentes } \\
\cline { 2 - 3 } $\begin{array}{l}\text { Graduação em } \\
\text { outra área }\end{array}$ & 2 & \multicolumn{1}{c}{$\%$} \\
\hline $\begin{array}{l}\text { Pós-Graduação } \\
\text { Lato Sensu }\end{array}$ & 9 & $65 \%$ \\
\hline $\begin{array}{l}\text { Graduação em } \\
\text { outra área e Pós- } \\
\text { Graduação Lato }\end{array}$ & 1 & $7 \%$ \\
$\begin{array}{l}\text { Sensu } \\
\text { Mestrado }\end{array}$ & & \\
\hline Doutorado & 1 & $7 \%$ \\
\hline $\begin{array}{l}\text { Não possuo } \\
\text { formação } \\
\text { complementar }\end{array}$ & 1 & $\mathbf{7 \%}$ \\
\hline \multicolumn{1}{c}{ Total } & 14 & $\mathbf{1 0 0 \%}$ \\
\hline
\end{tabular}

Fonte: a autora.

No questionário aplicado, foi dado ao respondente a opção de informar sobre sua formação complementar. Aqueles que o fizeram (7 respondentes) indicaram os seguintes cursos:

a) Pedagogia;

b) especializações em: Biblioteconomia, Administração Pública, Gestão em Biblioteca Pública e Docência na Educação Superior;

c) mestrado em Ciência da Informação.

Também foram informados cursos em andamento:

a) especialização em Administração Pública;

b) mestrado em Educação.

Todos os bibliotecários entrevistados demonstraram pretensão em complementar sua formação acadêmica, especialmente por meio de cursos de mestrado e doutorado. Dentre as justificativas apontadas estão:

a) fortalecimento da prática profissional, aliando o conhecimento teórico às experiências empíricas;

b) pretensão de seguir carreira docente em Ciência da Informação e/ou outras áreas do conhecimento;

c) realização pessoal;

d) incentivo financeiro. 
Ainda em relação à formação complementar, os dados apresentados na tabela 6 indicam que a Rede possui um quantitativo maior de profissionais detentores de cursos de pós-graduação lato sensu, quando cotejado a dados de pesquisas anteriores, como é o caso da pesquisa de Baptista (1998) onde apenas $26,8 \%$ dos bibliotecários eram detentores desse título e em relação ao estudo de Walter (2008) em que esse percentual era de $45,1 \%$, o que evidencia que os bibliotecários estão, cada vez mais, buscando o aperfeiçoamento profissional, por meio da educação continuada.

O domínio de línguas estrangeiras está entre as habilidades requeridas, segundo Castro (2000), tanto ao bibliotecário tradicional, quanto ao moderno profissional da Informação (MIP). Nesse sentido, o presente estudo também teve como propósito investigar o nível de compreensão em idiomas estrangeiros, do bibliotecário atuante no IFB.

A tabela 7 apresenta os resultados da pesquisa sobre 0 nível de conhecimento dos bibliotecários em idiomas estrangeiros. Os dados revelam que a maioria dos respondentes (64\%) não possui conhecimento em língua francesa, $29 \%$ detêm conhecimento básico e $7 \%$ conhecimento avançado.

Tabela 7 - Conhecimento em idiomas.

\begin{tabular}{|c|c|c|c|c|c|c|c|c|}
\hline \multirow[t]{2}{*}{$\begin{array}{l}\text { Nível de } \\
\text { Conhecimento } \\
\text { da Língua }\end{array}$} & \multicolumn{2}{|c|}{$\begin{array}{l}\text { Língua Espanhola } \\
\text { Respondentes }\end{array}$} & \multicolumn{2}{|c|}{$\begin{array}{l}\text { Língua Francesa } \\
\text { Respondentes }\end{array}$} & \multicolumn{2}{|c|}{$\begin{array}{l}\text { Língua Inglesa } \\
\text { Respondentes }\end{array}$} & \multicolumn{2}{|c|}{$\begin{array}{l}\text { Outros Idiomas } \\
\text { Respondentes }\end{array}$} \\
\hline & n & $\%$ & $n$ & $\%$ & n & $\%$ & $n$ & $\%$ \\
\hline $\begin{array}{l}\text { Não possui } \\
\text { conhecimento }\end{array}$ & 2 & $14 \%$ & 9 & $64 \%$ & 1 & $7 \%$ & 14 & $100 \%$ \\
\hline $\begin{array}{l}\text { Conhecimento } \\
\text { Básico }\end{array}$ & 8 & $57 \%$ & 4 & $29 \%$ & 7 & $50 \%$ & 0 & 0 \\
\hline $\begin{array}{l}\text { Conhecimento } \\
\text { Intermediário }\end{array}$ & 4 & $29 \%$ & 0 & $0 \%$ & 2 & $14 \%$ & 0 & 0 \\
\hline $\begin{array}{l}\text { Conhecimento } \\
\text { Avançado }\end{array}$ & 0 & $0 \%$ & 1 & $7 \%$ & 4 & $29 \%$ & 0 & 0 \\
\hline Total & 14 & $100 \%$ & 14 & $100 \%$ & 14 & $100 \%$ & 14 & $100 \%$ \\
\hline
\end{tabular}

Fonte: a autora.

Em relação à língua inglesa, conforme indicado na tabela 7, 50\% dos bibliotecários atestam possuir conhecimento básico, 29\% possuem conhecimento avançado, 14\% conhecimento intermediário e 7\% não possuem conhecimento da língua. 
Questionou-se, ainda, acerca do conhecimento dos bibliotecários em língua espanhola. De acordo com os resultados apresentados na tabela 7, nenhum dos profissionais possui conhecimento avançado no idioma e 14\% não têm conhecimento algum. Todavia, $57 \%$ possuem conhecimento básico e $29 \%$, o conhecimento intermediário.

O que pode ser observado, a partir da análise dos resultados obtidos na tabela 7 é que há a preponderância do nível de conhecimento básico nas línguas espanhola, francesa e inglesa e nenhum conhecimento em idiomas estrangeiros, além dos que foram mencionados. Esse resultado indica que há a necessidade de capacitação dos bibliotecários em idiomas, em atenção ao que advertem Duarte e Braga (2010) quando afirmam que a falta de domínio em idiomas pode tornar-se um obstáculo à recuperação da informação, além de prejudicar o desempenho de outras atribuições dos bibliotecários na instituição, tendo em vista que, de acordo com o Plano de Desenvolvimento Institucional do IFB (BRASIL. MINISTÉRIO DA EDUCAÇÃO, 2014b), o IFB, oferece cursos superiores e de capacitação em língua espanhola e inglesa.

Observa-se, de acordo com a tabela 8, que a maior parte dos bibliotecários que atuam no IFB (79\%) possui renda entre $R \$ 3.001,00$ a $R \$ 6.000,00,14 \%$ percebem vencimentos entre $R \$ 6.000,00$ e $R \$ 10.000,00$ e uma pequena parcela $(7 \%)$ aufere remuneração entre $R \$ 1.000,00$ e $R \$ 3.000$. Ressalta-se, ainda, que nenhum dos respondentes detém renda superior a $\mathrm{R} \$ 10.000,00$.

Tabela 8 - Faixa salarial.

\begin{tabular}{|c|c|c|}
\hline \multirow[t]{2}{*}{ Faixa Salarial } & \multicolumn{2}{|c|}{ Respondentes } \\
\hline & $n$ & $\%$ \\
\hline Até $\mathrm{R} \$ 1.000,00$ & 0 & $0 \%$ \\
\hline $\begin{array}{l}\mathrm{R} \$ 1.001,00 \mathrm{a} \\
3.000,00\end{array}$ & 1 & $7 \%$ \\
\hline $\begin{array}{l}\mathrm{R} \$ 3.001,00 \text { a } \mathrm{R} \$ \\
6.000,00\end{array}$ & 11 & $79 \%$ \\
\hline $\begin{array}{l}\mathrm{R} \$ 6.001,00 \text { a } \mathrm{R} \$ \\
10.000,00\end{array}$ & 2 & $14 \%$ \\
\hline $\begin{array}{l}\text { Acima de } R \$ \\
10.000,00\end{array}$ & 0 & $0 \%$ \\
\hline Total & 14 & $100 \%$ \\
\hline
\end{tabular}

Fonte: a autora. 
Apesar de todos os bibliotecários do IFB pertencerem à carreira de técnicos-administrativos em educação, essa discrepância salarial se deve provavelmente a fatores como o tempo de atuação na instituição e ao desenvolvimento e crescimento do profissional dentro da estrutura dessa carreira, conforme o disposto no art. 13, da Lei no 11.091, de 12 de janeiro de 2005:

[...] a remuneração dos integrantes do Plano de Carreira será composta do vencimento básico, correspondente ao valor estabelecido para o padrão de vencimento do nível de classificação e nível de capacitação ocupados pelo servidor, acrescido dos incentivos previstos nesta Lei e das demais vantagens pecuniárias estabelecidas em lei.

A tabela 9 ressalta quais são as funções exercidas pelos bibliotecários no IFB. No questionário da pesquisa foi facultado ao respondente assinalar mais de uma função. Sendo assim, o que se observa, de acordo com os resultados obtidos, é que uma parcela considerável desses profissionais exerce mais de uma função na biblioteca (35\%). Tal resultado confirma a posição de Baptista e Mueller (2005) ao afirmarem que o moderno profissional da informação deve possuir dinamismo, polivalência, multiespecialização, além de visão holística.

Tabela 9 - Função do bibliotecário na instituição.

\begin{tabular}{|c|c|c|}
\hline \multirow{2}{*}{ Função do Bibliotecário na Instituição } & \multicolumn{2}{|c|}{ Respondentes } \\
\hline & $\mathbf{n}$ & $\%$ \\
\hline Bibliotecário de Circulação de Materiais & 2 & $14 \%$ \\
\hline Bibliotecário de Processamento Técnico & 3 & $21 \%$ \\
\hline Bibliotecário de Referência & 0 & $0 \%$ \\
\hline Chefe de Seção & 0 & $0 \%$ \\
\hline Gestor de Unidade(s) de Informação & 3 & $21 \%$ \\
\hline Pesquisador & 0 & $0 \%$ \\
\hline $\begin{array}{l}\text { Bibliotecário de Circulação de Materiais, } \\
\text { Bibliotecário de Processamento Técnico, } \\
\text { Bibliotecário de Referência, Chefe de Seção }\end{array}$ & 1 & $7 \%$ \\
\hline $\begin{array}{l}\text { Bibliotecário de Circulação de Materiais, } \\
\text { Bibliotecário de Processamento Técnico, } \\
\text { Bibliotecário de Referência }\end{array}$ & 3 & $21 \%$ \\
\hline $\begin{array}{l}\text { Bibliotecário de Circulação de Materiais, } \\
\text { Bibliotecário de Processamento Técnico, } \\
\text { Bibliotecário de Referência, Gestor de } \\
\text { Unidade(s) de Informação }\end{array}$ & 1 & $7 \%$ \\
\hline Coordenador de Sistema de Bibliotecas & 1 & $7 \%$ \\
\hline Total & 14 & $100 \%$ \\
\hline
\end{tabular}

Fonte: a autora. 
Todavia, os bibliotecários apontaram, dentre as razões pelas quais necessitam exercer mais de uma atribuição no IFB, a quantidade reduzida de profissionais que são contratados para atuarem nas bibliotecas. De acordo com os entrevistados, o número de bibliotecários existentes no Instituto é insuficiente, tendo em vista o aumento constante das demandas que surgem, em decorrência da expansão da rede federal de ensino profissional e tecnológico no Distrito Federal.

Dentre a totalidade dos respondentes, $21 \%$ atuam apenas no serviço de processamento técnico; $21 \%$ exercem apenas a função de gestor de unidade de informação; $14 \%$ trabalham apenas com a circulação de materiais; $7 \%$ coordenam o sistema de bibliotecas; $21 \%$ atuam, simultaneamente, nos serviços de circulação de materiais, processamento técnico e referência: $7 \%$ atuam como bibliotecário de circulação de materiais, processamento técnico, referência e chefe de seção e 7\% atuam como bibliotecário de circulação de materiais, de processamento técnico, de referência e gestor de unidade de informação.

Um dado que chama a atenção é o resultado do item "pesquisador", pois, mesmo se tratando de instituição de ensino profissional e tecnológico, nenhum dos respondentes afirma trabalhar como pesquisador.

De modo geral, os entrevistados consideram-se pesquisadores. Entretanto, nenhum dos respondentes assinalou que atua como pesquisador no IFB, pois, de acordo com os bibliotecários, eles exercem suas funções sob um contexto mais técnico e prático do que intelectual. Conforme um dos respondentes:

\footnotetext{
A tríplice ensino, pesquisa e extensão é uma prática básica em instituições de ensino, porém, nossa realidade ainda não nos permite ter uma grande expressão na pesquisa e extensão, pois trabalhamos com comunidades carentes. $O$ ensino ainda é uma barreira que precisa ser quebrada antes de almejarmos a pesquisa e a extensão (informação verbal) $)^{4}$.
}

\footnotetext{
${ }^{4}$ Resposta do bibliotecário no 3 .
} 
De acordo com Rossi, Costa e Pinto (2014), para estarem suficientemente qualificados ao desempenho de suas atribuições em unidades de informação, os bibliotecários necessitam de sucessivas capacitações, com a finalidade de acompanhar as evoluções da tecnologia $e$ atender adequadamente às necessidades dos usuários. Para esse fim, segundo os autores, é necessário que as competências desses profissionais sejam identificadas, no intuito de proporcionar um aperfeiçoamento profissional compatível com as atividades desenvolvidas, tendo em vista a busca por melhorias nos serviços oferecidos e o desenvolvimento do bibliotecário na organização. Nessa perspectiva, buscou-se identificar em quais áreas os bibliotecários do IFB já haviam concluído cursos de aperfeiçoamento profissional.

A tabela 10 evidencia as áreas relacionadas aos cursos de capacitação que foram realizados pelos bibliotecários. Percebe-se, a partir dos resultados obtidos, que os cursos realizados por um maior número de bibliotecários são aqueles associados às atividades de natureza técnica, como "catalogação" (57\%), "classificação" (43\%) e "atendimento ao usuário / serviço de referência" (43\%).

Tabela 10 - Cursos de capacitação.

\begin{tabular}{|c|c|c|}
\hline \multirow{2}{*}{ Cursos de Capacitação } & \multicolumn{2}{|c|}{ Respondentes } \\
\hline & $\mathbf{n}$ & $\%$ \\
\hline Acessibilidade & 4 & $29 \%$ \\
\hline Ações Culturais / Pedagógicas & 3 & $21 \%$ \\
\hline $\begin{array}{l}\text { Ambientes Virtuais de Aprendizagem / } \\
\text { Educação à Distância }\end{array}$ & 2 & $14 \%$ \\
\hline $\begin{array}{l}\text { Atendimento ao Usuário / Serviço de } \\
\text { Referência }\end{array}$ & 6 & $43 \%$ \\
\hline Automação de Bibliotecas & 3 & $21 \%$ \\
\hline Bibliotecas Digitais & 2 & $14 \%$ \\
\hline Catalogação & 8 & $57 \%$ \\
\hline Classificação & 6 & $43 \%$ \\
\hline Desenvolvimento de Coleções & 2 & $14 \%$ \\
\hline Documentação & 3 & $21 \%$ \\
\hline $\begin{array}{l}\text { Gerenciamento de Unidade de } \\
\text { Informação }\end{array}$ & 3 & $21 \%$ \\
\hline Inclusão Social & 1 & $7 \%$ \\
\hline Indexação & 4 & $29 \%$ \\
\hline Normas Técnicas (ABNT) & 4 & $29 \%$ \\
\hline Tecnologia da Informação & 2 & $14 \%$ \\
\hline Não Possui & 2 & $14 \%$ \\
\hline Total & 14 & $100 \%$ \\
\hline
\end{tabular}

Fonte: a autora. 
Essa busca por cursos direcionados ao desenvolvimento de habilidades em áreas técnicas pode ser justificada a partir dos relatos dos próprios bibliotecários, já que a maioria desses profissionais enfatizou o desempenho de funções mais técnicas do que intelectuais no IFB.

Os percentuais da tabela 11 apresentam, de acordo com a opinião dos respondentes, quais são as características que o bibliotecário deve possuir, para atuar no IFB (considerando-se o maior grau de relevância):
a) proatividade $(72 \%)$;
b) saber trabalhar em equipe (72\%);
c) bom relacionamento interpessoal $(57 \%)$;
d) saber comunicar-se (57\%); e
e) espírito crítico (43\%).

Tabela 11 - Características que o bibliotecário deve possuir para atuar no IFB.

\begin{tabular}{|c|c|c|c|c|c|c|c|}
\hline RELEI & $\mathrm{ICIA}$ & & & & & & \\
\hline $\begin{array}{l}\text { QUE O BIBLIOTECÁRIO } \\
\text { DEVE POSSUIR PARA } \\
\text { ATUAR NO IFB. }\end{array}$ & & $\begin{array}{c}\text { SEM } \\
\text { RELEVÂNCIA }\end{array}$ & $\begin{array}{c}\text { POUCO } \\
\text { RELEVANTE }\end{array}$ & $\begin{array}{l}\text { MEDIANAMENTE } \\
\text { RELEVANTE }\end{array}$ & $\begin{array}{c}\text { MUITO } \\
\text { RELEVANTE }\end{array}$ & $\begin{array}{l}\text { TOTALMENTE } \\
\text { RELEVANTE }\end{array}$ & TOTAL \\
\hline DPOATIYIDADF & $\mathrm{n}$ & 0 & 1 & 2 & 1 & 10 & 14 \\
\hline PRUAIIVIDADE & $\%$ & $0 \%$ & $7 \%$ & $14 \%$ & $7 \%$ & $72 \%$ & $100 \%$ \\
\hline & $\mathrm{n}$ & 0 & 1 & 3 & 4 & 6 & 14 \\
\hline 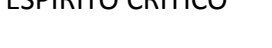 & $\%$ & $0 \%$ & $7 \%$ & $21 \%$ & $29 \%$ & $43 \%$ & $100 \%$ \\
\hline DOMÍNIO DE UMA & $\mathrm{n}$ & 0 & 4 & 5 & 4 & 1 & 14 \\
\hline $\begin{array}{l}\text { EINGUA } \\
\text { ESTRANGEIRA }\end{array}$ & $\%$ & $0 \%$ & $29 \%$ & $35 \%$ & $29 \%$ & $7 \%$ & $100 \%$ \\
\hline BOM & $\mathrm{n}$ & 0 & 1 & 1 & 4 & 8 & 14 \\
\hline $\begin{array}{l}\text { RELACIONAIMINIO } \\
\text { INTERPESSOAL }\end{array}$ & $\%$ & $0 \%$ & $7 \%$ & $7 \%$ & $29 \%$ & $57 \%$ & $100 \%$ \\
\hline SABER COMUNICAR- & $\mathrm{n}$ & 0 & 1 & 0 & 5 & 8 & 14 \\
\hline SE & $\%$ & $0 \%$ & $7 \%$ & $0 \%$ & $36 \%$ & $57 \%$ & $100 \%$ \\
\hline HABILIDADES & $\mathrm{n}$ & 0 & 1 & 4 & 5 & 4 & 14 \\
\hline PEDAGÓGICAS & $\%$ & $0 \%$ & $7 \%$ & $29 \%$ & $35 \%$ & $29 \%$ & $100 \%$ \\
\hline SABER TRABALHAR & $\mathrm{n}$ & 1 & 1 & 0 & 2 & 10 & 14 \\
\hline EM EQUIPE & $\%$ & $7 \%$ & $7 \%$ & $0 \%$ & $14 \%$ & $72 \%$ & $100 \%$ \\
\hline
\end{tabular}

Fonte: a autora. 
O resultado obtido na tabela 11 ratifica as análises de Mason (1990) no sentido de caracterizar o bibliotecário no contexto da sociedade da informação como aquele que possui um perfil proativo e interativo; e de Araújo e Dias (2005), que correlacionam a proatividade desse profissional à função de dinamização da informação.

Outra variável atribuída pelos respondentes como característica inerente ao bibliotecário que atua no IFB e que consta no item 3.4.2 desta pesquisa, é a atuação em equipe. A importância dessa capacidade já vem sendo citada na literatura por autores como Tarapanoff (1988), há quase 30 anos, e Arruda, Marteleto e Souza (2000) há 15 anos. Esses autores defendiam que o perfil do bibliotecário deveria contemplar características como a flexibilidade, busca constante por aperfeiçoamento profissional, além de saber trabalhar em equipe e ambientes colaborativos.

Cunha (2003) também destaca o trabalho em equipes multidisciplinares, a proatividade, habilidades em relacionamento interpessoal e em comunicação, apontando, inclusive, a comunicação da informação como uma das tarefas essenciais ao bibliotecário.

Trazendo uma abordagem mais contemporânea, Dib e Silva (2009, p. 19) consideram que 0 trabalho em equipe configura-se como um diferencial competitivo nas organizações,

[...] pois possibilita, através do fazer coletivo, o desenvolvimento de serviços e produtos com valor agregado, na medida em que une pessoas com conhecimentos complementares, tendo metas e objetivos em comum. Trabalhar em equipe favorece, também, o crescimento pessoal de cada indivíduo, uma vez que viabiliza a troca de experiências.

A tabela 12 apresenta o resultado da pesquisa referente ao grau de relevância de cursos de capacitação, para o exercício profissional do bibliotecário que atua no IFB, de acordo com os respondentes. Considerando-se o maior grau de relevância (totalmente relevante), verifica-se que os cursos de maior pertinência são:

a) atendimento ao usuário/serviço de referência (65\%);

b) gerenciamento de unidades de informação (65\%);

c) ações culturais (50\%); 
d) bibliotecas digitas (50\%);

e) automação de bibliotecas (43\%);

f) desenvolvimento de coleções (43\%); e

g) relacionamento interpessoal (43\%).

Tabela 12 - Relevância dos cursos de capacitação para o exercício profissional do bibliotecário que atua no IFB.

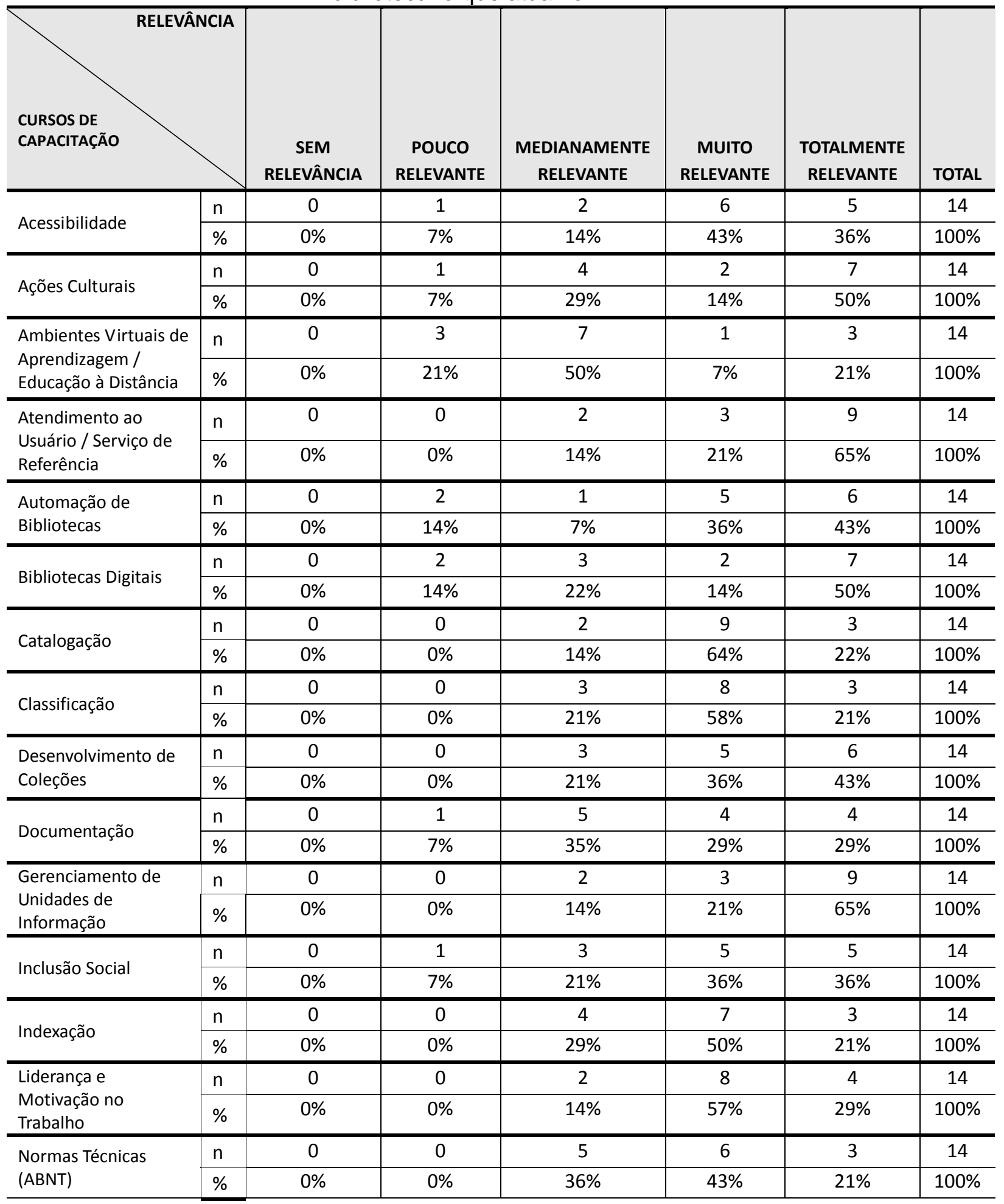


Tabela 12 - Relevância dos cursos de capacitação para o exercício profissional do bibliotecário que atua no IFB.

(Cont.)

\begin{tabular}{|c|c|c|c|c|c|c|c|}
\hline \multirow{2}{*}{$\begin{array}{l}\text { Relacionamento } \\
\text { Interpessoal }\end{array}$} & $\mathrm{n}$ & 0 & 1 & 2 & 5 & 6 & 14 \\
\hline & $\%$ & $0 \%$ & $7 \%$ & $14 \%$ & $36 \%$ & $43 \%$ & $100 \%$ \\
\hline \multirow{2}{*}{$\begin{array}{l}\text { Técnicas de } \\
\text { Negociação e } \\
\text { Resolução de } \\
\text { Conflitos }\end{array}$} & $n$ & 0 & 1 & 1 & 7 & 5 & 14 \\
\hline & $\%$ & $0 \%$ & $7 \%$ & $7 \%$ & $50 \%$ & $36 \%$ & $100 \%$ \\
\hline \multirow{2}{*}{$\begin{array}{l}\text { Tecnologias da } \\
\text { Informação }\end{array}$} & $\mathrm{n}$ & 0 & 0 & 3 & 6 & 5 & 14 \\
\hline & $\%$ & $0 \%$ & $0 \%$ & $21 \%$ & $43 \%$ & $36 \%$ & $100 \%$ \\
\hline
\end{tabular}

Fonte: a autora.

Ressalta-se, ainda, os cursos de capacitação que foram considerados como "muito relevantes", conforme os resultados apresentados na tabela 12:
a) catalogação (64\%);
b) classificação (58\%);
c) liderança e motivação no trabalho (57\%);
d) indexação (50\%);
e) técnicas de negociação e resolução de conflitos (50\%);
f) acessibilidade (43\%);
g) normas técnicas (43\%); e
h) tecnologias da informação (43\%).

É possível notar, de acordo com os dados constantes na tabela 12, que os principais cursos considerados totalmente relevantes são aqueles relacionados ao atendimento ao usuário, gerenciamento de unidades de informação, além de cursos referentes a ações culturais e bibliotecas digitais. Não obstante, observase, ao confrontar os dados obtidos na tabela 12 com aqueles relacionados na tabela 10, que os cursos de aperfeiçoamento profissional realizados, efetivamente, pelos bibliotecários, ainda estão aquém daqueles que os mesmos julgam ser relevantes ao desempenho de suas atividades no IFB.

Ainda assim, os resultados obtidos em relação aos cursos de capacitação que o bibliotecário deve possuir para trabalhar no IFB vão ao encontro do pensamento de Silva e Cunha (2002, p. 82), quando afirmam que "[...] o papel mais importante do bibliotecário no século XXI parece ainda ser o de gerenciador da informação". As autoras sustentam, também, que o trabalho do bibliotecário está relacionado à mediação, à comunicação entre as informações e as pessoas 
e que o novo perfil desse profissional deve estar em consonância com o saber técnico, conhecimento, vivências culturais e tecnologias da informação.

Em relação aos fatores que influenciaram os bibliotecários a seguirem carreira na Rede Federal de Ensino do Distrito Federal, destacam-se os seguintes, conforme o maior grau de relevância (totalmente relevante) apresentados na tabela 13:

a) estabilidade no emprego (57\%); e

b) identificação com a filosofia da instituição (43\%).

Outros estudos acerca do tema "carreira no serviço público federal" também apontam o quesito "estabilidade no emprego" dentre os principais fatores que influenciam o indivíduo a seguir uma carreira pública.

Souza e Moulin (2014), por exemplo, realizaram um estudo no intuito de revelar quais eram os sentidos atribuídos ao trabalho por servidores públicos de uma instituição integrante da Rede Federal de Ensino do Espírito Santo. A pesquisa foi feita com servidores de diversos cargos, inclusive bibliotecários.

De acordo com Souza e Moulin (2014, p. 58), o cargo público é indicado, pelos respondentes da pesquisa, como "[...] mediador que assegura tranquilidade e estabilidade à vida material". Segundo as autoras,

[...] o serviço público, em comparação com o setor privado, oferece uma condição de maior estabilidade ao trabalhador, o que possibilita, em certa medida, maior planejamento e estruturação da vida. Essa "promessa" de estabilidade, face à crise mundial do desemprego e à precariedade do trabalho no mundo contemporâneo, tem motivado uma corrida para os concursos públicos nos últimos anos.

Ainda em relação aos resultados apresentados na tabela 13, nota-se que a variável "remuneração" não obteve um grau de relevância considerável, por parte dos respondentes.

Os bibliotecários entrevistados atestaram que a remuneração não foi um item relevante, dentre aqueles que os influenciaram na decisão de trabalhar no IFB, pois há outras carreiras mais atrativas. Segundo os bibliotecários, existiram outros fatores que foram levados em conta: 
[...] o ambiente de trabalho é muito bom, a existência de vários campi com a possibilidade de trabalhar próximo de casa e o plano de carreira com incentivo ao Mestrado e Doutorado, acredito que sejam fatores para querer continuar na carreira no IFB (informação verbal) ${ }^{5}$;

[...] porque o salário não é atrativo se comparado à carreira legislativa e judiciária (informação verbal) ${ }^{6}$;

[...] o horário flexível e disponibilidade de várias opções de locais de trabalho (campus) pesam mais na decisão (informação verbal);

[...] o ambiente de trabalho é tranquilo e o bibliotecário tem uma certa autonomia para realizar suas atividades (informação verbal) 8 ;

[...] existem, realmente, outros fatores mais atrativos e relevantes para continuar na rede, como, por exemplo, a flexibilidade e incentivo de cursar um mestrado e doutorado (informação verbal) ${ }^{9}$.

Tabela 13 - Itens que influenciaram o bibliotecário na decisão de trabalhar no IFB.

\begin{tabular}{l|l|c|c|c|c|c|c}
\hline \multicolumn{1}{l}{ RELEVÂNCIA } & & & & & \\
\end{tabular}

Fonte: a autora.

\footnotetext{
${ }^{5}$ Resposta do bibliotecário no 3 .

${ }^{6}$ Resposta do bibliotecário no 4 .

${ }^{7}$ Resposta do bibliotecário no 6 .

${ }^{8}$ Resposta do bibliotecário № 7.

${ }^{9}$ Resposta do bibliotecário no 8 .
} 
Tabela 13 - Itens que influenciaram o bibliotecário na decisão de trabalhar no IFB. (cont.)

\begin{tabular}{|c|c|c|c|c|c|c|c|}
\hline RELEVÂNCI & & & & & & & \\
\hline $\begin{array}{l}\text { INFLUENCIARAM } \\
\text { PARA A DECISÃO DE } \\
\text { TRABALHAR NO IFB }\end{array}$ & \multicolumn{2}{|c|}{ SEM RELEVÂNCIA } & $\begin{array}{c}\text { POUCO } \\
\text { RELEVANTE }\end{array}$ & $\begin{array}{l}\text { MEDIANAMENTE } \\
\text { RELEVANTE }\end{array}$ & $\begin{array}{c}\text { MUITO } \\
\text { RELEVANTE }\end{array}$ & $\begin{array}{l}\text { TOTALMENTE } \\
\text { RELEVANTE }\end{array}$ & TOTAL \\
\hline \multirow{2}{*}{$\begin{array}{l}\text { POSSIBILIDADE DE } \\
\text { APLICAR O } \\
\text { CONHECIMENTO } \\
\text { ADQUIRIDO } \\
\end{array}$} & $\mathrm{n}$ & 0 & 2 & 2 & 5 & 5 & 14 \\
\hline & $\%$ & $0 \%$ & $14 \%$ & $14 \%$ & $36 \%$ & $36 \%$ & $100 \%$ \\
\hline \multirow{2}{*}{$\begin{array}{l}\text { POSSIBILIDADE DE } \\
\text { ASCENSÃO } \\
\text { PROFISSIONAL }\end{array}$} & $n$ & 1 & 3 & 5 & 4 & 1 & 14 \\
\hline & $\%$ & $7 \%$ & $21 \%$ & $36 \%$ & $29 \%$ & $7 \%$ & $100 \%$ \\
\hline \multirow{2}{*}{ PRESTÍGIO } & $n$ & 3 & 4 & 7 & 0 & 0 & 14 \\
\hline & $\%$ & $21 \%$ & $29 \%$ & $50 \%$ & $0 \%$ & $0 \%$ & $100 \%$ \\
\hline \multirow{2}{*}{ REMUNERAÇÃO } & $n$ & 0 & 3 & 7 & 3 & 1 & 14 \\
\hline & $\%$ & $0 \%$ & $21 \%$ & $50 \%$ & $21 \%$ & $7 \%$ & $100 \%$ \\
\hline
\end{tabular}

Fonte: a autora.

\subsubsection{Competências Mapeadas}

As tabelas 14 a 17 referem-se às questões atinentes ao segundo bloco do questionário e apresentam os resultados do mapeamento das competências que os respondentes consideraram importantes para a atuação do bibliotecário que exerce suas atividades na Rede Federal de Ensino do Distrito Federal. O mapeamento foi sistematizado de acordo com o seguinte conjunto de competências:

a) competências em comunicação e expressão;

b) competências técnico-científicas;

c) competências gerenciais; e

d) competências sociais e políticas.

Segundo Câmara e Borges (2011, p. 10) as competências em comunicação compreendem "[...] a capacidade de interação, argumentação, partilha, trabalho colaborativo e participação em redes e comunidades [...]" conforme a relevância para cada indivíduo ou organização. 
Competências em comunicação e expressão são competências consideradas essenciais nas organizações. Essa afirmação é atestada tanto em pesquisas nacionais, quanto em estudos internacionais relacionados ao perfil do bibliotecário contemporâneo, de acordo com Belluzzo (2011).

Nota-se, ao analisar a tabela 14, que a maioria dos respondentes considerou as competências associadas à comunicação e expressão totalmente relevantes, destacando-se:

a) capacidade de comunicação e interação com os usuários da informação $(71 \%)$;

b) capacidade de orientar os usuários para um melhor uso dos recursos de informação (64\%); e

c) capacidade de disseminação dos produtos e serviços oferecidos pela biblioteca (57\%).

Tabela 14 - Competências em comunicação e expressão.

\begin{tabular}{|c|c|c|c|c|c|c|c|}
\hline \multicolumn{2}{|c|}{\begin{tabular}{|l|} 
RELEVÂNCIA \\
\end{tabular}} & \multirow[b]{2}{*}{$\begin{array}{c}\text { SEM } \\
\text { RELEVÂNCIA }\end{array}$} & \multirow[b]{2}{*}{$\begin{array}{c}\text { POUCO } \\
\text { RELEVANTE }\end{array}$} & \multirow[b]{2}{*}{$\begin{array}{l}\text { MEDIANAMENTE } \\
\text { RELEVANTE }\end{array}$} & \multirow[b]{2}{*}{$\begin{array}{c}\text { MUITO } \\
\text { RELEVANTE }\end{array}$} & \multirow[b]{2}{*}{$\begin{array}{l}\text { TOTALMENTE } \\
\text { RELEVANTE }\end{array}$} & \multirow{2}{*}{ TOTAL } \\
\hline $\begin{array}{l}\text { EM COMUNICAÇÃOO } \\
\text { E EXPRESSÃ̃O }\end{array}$ & & & & & & & \\
\hline $\begin{array}{l}\text { CAPACIDADE DE } \\
\text { ORIENTAR OS } \\
\text { USUÁRIOS PARA UM }\end{array}$ & $\mathrm{n}$ & 0 & 0 & 0 & 5 & 9 & 14 \\
\hline $\begin{array}{l}\text { MELHOR USO DOS } \\
\text { RECURSOS DE } \\
\text { INFORMAÇÃO }\end{array}$ & $\%$ & $0 \%$ & $0 \%$ & $0 \%$ & $36 \%$ & $64 \%$ & $100 \%$ \\
\hline CAPACIDADE DE & $\mathrm{n}$ & 0 & 0 & 0 & 4 & 10 & 14 \\
\hline $\begin{array}{l}\text { INTERAÇÃO COM OS } \\
\text { USUÁRIOS DA } \\
\text { INFORMAÇÃO }\end{array}$ & $\%$ & $0 \%$ & $0 \%$ & $0 \%$ & $29 \%$ & $71 \%$ & $100 \%$ \\
\hline $\begin{array}{l}\text { CAPACIDADE DE } \\
\text { COMUNICACÃO E }\end{array}$ & $\mathrm{n}$ & 0 & 0 & 4 & 4 & 6 & 14 \\
\hline $\begin{array}{l}\text { INTERAÇÃO COM OS } \\
\text { DEMAIS SERVIDORES } \\
\text { DA BIBLIOTECA }\end{array}$ & $\%$ & $0 \%$ & $0 \%$ & $29 \%$ & $29 \%$ & $43 \%$ & $100 \%$ \\
\hline CAPACIDADE DE & $\mathrm{n}$ & 0 & 0 & 2 & 6 & 6 & 14 \\
\hline INFORMAÇÃO & $\%$ & $0 \%$ & $0 \%$ & $14 \%$ & $43 \%$ & $43 \%$ & $100 \%$ \\
\hline $\begin{array}{l}\text { CAPACIDADE DE } \\
\text { DISSEMINAÇÃO DE } \\
\text { PRODUTOS E }\end{array}$ & $\mathrm{n}$ & 0 & 1 & 1 & 4 & 8 & 14 \\
\hline $\begin{array}{l}\text { SERVIÇOS } \\
\text { OFERECIDOS PELA } \\
\text { BIBLIOTECA }\end{array}$ & $\%$ & $0 \%$ & $7 \%$ & $7 \%$ & $29 \%$ & $57 \%$ & $100 \%$ \\
\hline
\end{tabular}

Fonte: a autora. 
A partir da análise dos resultados apresentados nas tabelas 12 e 14, é possível constatar a significância atribuída pelos bibliotecários do IFB ao desenvolvimento de competências relacionadas com o atendimento ao usuário. $\mathrm{Na}$ tabela 12, verifica-se que os cursos de capacitação que possuem maior relevância são aqueles voltados ao atendimento do usuário. Mais adiante, na tabela 14, os dados coletados contribuem para intensificar essa importância, haja vista a expressividade dos resultados das variáveis "capacidade de orientar os usuários para um melhor uso dos recursos de informação", com 100\% de relevância (considerando as alternativas "muito relevante" e "totalmente relevante") e "capacidade de comunicação e interação com os usuários da informação", também com 100\% de relevância.

Estudos como os de Belluzzo (1999) também apontam essa tendência de busca, por parte das unidades de informação e do próprio bibliotecário, de programas e/ou cursos de aperfeiçoamento profissional que priorizem o serviço de referência e em especial o atendimento ao usuário.

Lopez Diaz, Perez Matos e Remigio (2007), afirmam que as competências técnico-científicas estão relacionadas ao "saber", ou seja, referem-se ao conjunto de conhecimentos relacionados a atributos de competência, seja através da experiência do indivíduo ou por métodos de ensino e aprendizagem.

O mapeamento, consoante à tabela 15 , teve como objetivo, verificar quais dos "saberes" elencados possuem maior relevância para o exercício da atividade profissional do bibliotecário no IFB. De acordo com os respondentes, as competências técnico-científicas mais indicadas foram:

a) capacidade de utilizar e disseminar fontes, produtos e recursos de informação, em diferentes suportes (58\%);

b) capacidade de pesquisa e domínio das diversas fontes de informação (57\%);

c) capacidade de elaborar produtos de informação (50\%);

d) capacidade de utilizar recursos de acessibilidade (50\%);

e) capacidade de utilizar recursos da tecnologia da informação (43\%). 
Tabela 15 - Competências técnico-científicas.

\begin{tabular}{|c|c|c|c|c|c|c|c|}
\hline \multicolumn{2}{|c|}{\begin{tabular}{|l|} 
RELEVÂNCIA \\
\end{tabular}} & \multirow[b]{2}{*}{$\begin{array}{c}\text { SEM } \\
\text { RELEVÂNCIA }\end{array}$} & \multirow[b]{2}{*}{$\begin{array}{c}\text { POUCO } \\
\text { RELEVANTE }\end{array}$} & \multirow[b]{2}{*}{$\begin{array}{l}\text { MEDIANAMENTE } \\
\text { RELEVANTE }\end{array}$} & \multirow[b]{2}{*}{$\begin{array}{c}\text { MUITO } \\
\text { RELEVANTE }\end{array}$} & \multirow[b]{2}{*}{$\begin{array}{l}\text { TOTALMENTE } \\
\text { RELEVANTE }\end{array}$} & \multirow[b]{2}{*}{ TOTAL } \\
\hline TÉCNIC & & & & & & & \\
\hline $\begin{array}{l}\text { CAPACIDADE DE } \\
\text { DESENVOLVER E } \\
\text { EXECUTAR O }\end{array}$ & $\mathrm{n}$ & 0 & 1 & 5 & 5 & 3 & 14 \\
\hline $\begin{array}{l}\text { PROCESSAMENTO DE } \\
\text { DOCUMENTOS EM } \\
\text { DISTINTOS SUPORTES }\end{array}$ & $\%$ & $0 \%$ & $7 \%$ & $36 \%$ & $36 \%$ & $21 \%$ & $100 \%$ \\
\hline $\begin{array}{l}\text { CAPACIDADE DE } \\
\text { SELECIONAR E } \\
\text { DIFUNDIR A } \\
\text { INFORMACCÃO }\end{array}$ & $\mathrm{n}$ & 0 & 1 & 5 & 3 & 5 & 14 \\
\hline $\begin{array}{l}\text { GRAVADA EM } \\
\text { QUALQUER MEIO } \\
\text { PARA OS USUÁRIOS }\end{array}$ & $\%$ & $0 \%$ & $7 \%$ & $36 \%$ & $21 \%$ & $36 \%$ & $100 \%$ \\
\hline $\begin{array}{l}\text { CAPACIDADE DE } \\
\text { ELABORAR }\end{array}$ & $\mathrm{n}$ & 0 & 1 & 2 & 4 & 7 & 14 \\
\hline $\begin{array}{l}\text { PRODUTOS DE } \\
\text { INFORMAÇÃO }\end{array}$ & $\%$ & $0 \%$ & $7 \%$ & $14 \%$ & $29 \%$ & $50 \%$ & $100 \%$ \\
\hline $\begin{array}{l}\text { CAPACIDADE DE } \\
\text { UTILIZAR E } \\
\text { DISSEMINAR FONTES, } \\
\text { PRODUTOSE }\end{array}$ & $\mathrm{n}$ & 0 & 1 & 2 & 3 & 8 & 14 \\
\hline $\begin{array}{l}\text { RECURSOS DE } \\
\text { INFORMAÇÃO EM } \\
\text { DIFERENTES } \\
\text { SUPORTES }\end{array}$ & $\%$ & $0 \%$ & $7 \%$ & $14 \%$ & $21 \%$ & $58 \%$ & $100 \%$ \\
\hline $\begin{array}{l}\text { CAPACIDADE DE } \\
\text { FORMULAR } \\
\text { POLÍTICAS DE } \\
\text { PESQUISA EM }\end{array}$ & $\mathrm{n}$ & 0 & 1 & 6 & 4 & 3 & 14 \\
\hline $\begin{array}{l}\text { BIBLIOTECONOMIA E } \\
\text { CIÊNCIA DA } \\
\text { INFORMAÇÃO }\end{array}$ & $\%$ & $0 \%$ & $7 \%$ & $43 \%$ & $29 \%$ & $21 \%$ & $100 \%$ \\
\hline CAPACIDADE DE & $\mathrm{n}$ & 0 & 0 & 1 & 5 & 8 & 14 \\
\hline $\begin{array}{l}\text { DAS DIVERSAS } \\
\text { FONTES DE } \\
\text { INFORMAÇÃO }\end{array}$ & $\%$ & $0 \%$ & $0 \%$ & $7 \%$ & $36 \%$ & $57 \%$ & $100 \%$ \\
\hline CAPACIDADE DE & $\mathrm{n}$ & 0 & 0 & 1 & 7 & 6 & 14 \\
\hline $\begin{array}{l}\text { DA TECNOLOGIA DA } \\
\text { INFORMAÇÃOO }\end{array}$ & $\%$ & $0 \%$ & $0 \%$ & $7 \%$ & $50 \%$ & $43 \%$ & $100 \%$ \\
\hline CAPACIDADE DE & $\mathrm{n}$ & 0 & 1 & 0 & 6 & 7 & 14 \\
\hline DE ACESSIBILIDADE & $\%$ & $0 \%$ & $7 \%$ & $0 \%$ & $43 \%$ & $50 \%$ & $100 \%$ \\
\hline $\begin{array}{l}\text { CAPACIDADE DE } \\
\text { UTILIZAR RECURSOS } \\
\text { DE EDUCAÇÃO À } \\
\text { DISTÂNCIA }\end{array}$ & $\begin{array}{l}\mathrm{n} \\
\%\end{array}$ & $\begin{array}{c}0 \\
0 \%\end{array}$ & $\begin{array}{c}1 \\
7 \%\end{array}$ & $\begin{array}{c}4 \\
29 \%\end{array}$ & $\begin{array}{c}5 \\
35 \%\end{array}$ & $\begin{array}{c}4 \\
29 \%\end{array}$ & $\begin{array}{c}14 \\
100 \%\end{array}$ \\
\hline
\end{tabular}

Fonte: a autora. 
Observa-se, ao cotejar os resultados obtidos na tabela 14 com aqueles elencados na tabela 15, a importância atribuída à variável "disseminação da informação". Interessante notar que a mesma variável é considerada totalmente relevante tanto sob o ponto de vista da comunicação, quanto relacionada ao desenvolvimento de habilidades técnico-científicas, que possibilitem ao profissional o compartilhamento de informações por meio dos mais diferentes suportes, refletindo, dessa maneira, a preocupação do bibliotecário em relação ao seu papel de gestor da informação.

Verifica-se, ainda sob a análise da tabela 15, que, se os percentuais forem considerados a partir do somatório da alternativa "muito relevante" e "totalmente relevante" é possível atestar que a maioria dos respondentes atribuiu grau elevado de relevância a todos os itens arrolados, para o mapeamento das competências técnico-científicas. Tamanho grau de relevância permite depreender que os respondentes, assim como Ruzzarin, Amaral e Simionovschi (2006) associam o desenvolvimento de competências técnico-científicas à viabilização de um desempenho superior no trabalho.

Por meio da entrevista, também foi possível certificar a importância conferida pelos bibliotecários do IFB às competências técnico-científicas, tendo em vista que os entrevistados admitem que exercem, dentre outras funções, aquelas de caráter técnico. Ao analisar a tabela 10, também é possível constatar a importância das competências técnico-científicas para o trabalho do bibliotecário, visto que a maioria dos respondentes buscou cursos de capacitação relacionados aos trabalhos técnicos que são desempenhados nas bibliotecas.

[...] o trabalho que é desenvolvido no IFB, hoje, é mais técnico do que intelectual. As bibliotecas estão focadas nos processos de adequação do acervo, de espaço e no processamento técnico de materiais [...] (informação verbal) ${ }^{10}$.

Bitencourt (2001) defendia, em 2001, que as competências gerencias vão além daquelas oriundas da formação técnica. Para a autora, além das capacidades relacionadas à aprendizagem teórica, as competências gerenciais correlacionam-se, também, às ações praticadas no ambiente organizacional.

\footnotetext{
${ }^{10}$ Resposta do bibliotecário no 4 .
} 
Seguindo essa linha de raciocínio, vislumbrou-se, na pesquisa relacionada às competências gerenciais, evidenciar a percepção do bibliotecário que atua no IFB, sobre quais as competências de maior pertinência para o exercício de suas atividades na Instituição.

A capacidade de gerenciar unidades, sistemas e serviços de informação, foi considerada, conforme os resultados apresentados na tabela 16, totalmente relevante por $57 \%$ dos respondentes. Somando-se esse percentual à porcentagem da alternativa "muito relevante", constata-se que a relevância dessa competência chega a 100\%.

Tabela 16: Competências gerenciais.

\begin{tabular}{|c|c|c|c|c|c|c|c|}
\hline RELEV & CIA & & & & & & \\
\hline GERENCIAIS & & $\begin{array}{c}\text { SEM } \\
\text { RELEVÂNCIA }\end{array}$ & $\begin{array}{c}\text { POUCO } \\
\text { RELEVANTE }\end{array}$ & $\begin{array}{l}\text { MEDIANAMENTE } \\
\text { RELEVANTE }\end{array}$ & $\begin{array}{c}\text { MUITO } \\
\text { RELEVANTE }\end{array}$ & $\begin{array}{l}\text { TOTALMENTE } \\
\text { RELEVANTE }\end{array}$ & TOTAL \\
\hline $\begin{array}{l}\text { CAPACIDADE DE } \\
\text { GERENCIAR }\end{array}$ & $\mathrm{n}$ & 0 & 0 & 0 & 6 & 8 & 14 \\
\hline $\begin{array}{l}\text { SISTEMAS E } \\
\text { SERVIÇOS DE } \\
\text { INFORMAÇÃO }\end{array}$ & $\%$ & $0 \%$ & $0 \%$ & $0 \%$ & $43 \%$ & $57 \%$ & $100 \%$ \\
\hline $\begin{array}{l}\text { CAPACIDADE DE } \\
\text { GERENCIAR }\end{array}$ & $\mathrm{n}$ & 0 & 1 & 2 & 4 & 7 & 14 \\
\hline $\begin{array}{l}\text { PROJETOS DE } \\
\text { GESTÃO DA } \\
\text { INFORMAÇÃO }\end{array}$ & $\%$ & $0 \%$ & $7 \%$ & $14 \%$ & $29 \%$ & $50 \%$ & $100 \%$ \\
\hline $\begin{array}{l}\text { CAPACIDADE DE } \\
\text { APLICAR }\end{array}$ & $\mathrm{n}$ & 0 & 1 & 3 & 4 & 6 & 14 \\
\hline $\begin{array}{l}\text { MARKETING, DE } \\
\text { LIDERANÇA E DE } \\
\text { RELAÇÕES } \\
\text { PÚBLICAS }\end{array}$ & $\%$ & $0 \%$ & $7 \%$ & $21 \%$ & $29 \%$ & $43 \%$ & $100 \%$ \\
\hline $\begin{array}{l}\text { CAPACIDADE DE } \\
\text { PLANEJAR E } \\
\text { GERENCIAR }\end{array}$ & $\mathrm{n}$ & 0 & 1 & 1 & 6 & 6 & 14 \\
\hline $\begin{array}{l}\text { ECONÔMICOS, } \\
\text { FINANCEIROS E } \\
\text { HUMANOS }\end{array}$ & $\%$ & $0 \%$ & $7 \%$ & $7 \%$ & $43 \%$ & $43 \%$ & $100 \%$ \\
\hline $\begin{array}{l}\text { CAPACIDADE DE } \\
\text { PLANEJAR, } \\
\text { COORDENAR E }\end{array}$ & $\mathrm{n}$ & 0 & 2 & 1 & 7 & 4 & 14 \\
\hline $\begin{array}{l}\text { AVALIAR A } \\
\text { PRESERVAÇÃO E } \\
\text { CONSERVAÇÃO } \\
\text { DOCUMENTAL }\end{array}$ & $\%$ & $0 \%$ & $14 \%$ & $7 \%$ & $50 \%$ & $29 \%$ & $\begin{array}{l}100 \% \\
\text { ntinua.. }\end{array}$ \\
\hline
\end{tabular}

Fonte: a autora. 
Tabela 16: Competências gerenciais.

\begin{tabular}{l|c|c|c|c|c|c|c} 
(CONT.) & & & & & \\
\hline
\end{tabular}

Fonte: a autora.

Em menor percentual, mas em grau de relevância considerável, foram mapeadas, ainda, as seguintes competências, conforme a tabela 16:

a) capacidade de gerenciar projetos de gestão da informação;

b) capacidade de aplicar técnicas de marketing, de liderança e de relações públicas;

c) capacidade de planejar e gerenciar recursos econômicos, financeiros e humanos;

d) capacidade de planejar e desenvolver estudos de usuários da informação;

e) capacidade de gerenciar redes colaborativas de informação;

f) capacidade de planejar, coordenar e avaliar a preservação e conservação documental.

Em relação ao mapeamento das competências sociais e políticas, os respondentes atribuíram maior grau de relevância, segundo os percentuais constantes na tabela 17, à capacidade de promover ações de incentivo à leitura e à pesquisa científica (57\%). Em uma pesquisa voltada especificamente para verificar a atuação do bibliotecário na formação de leitores nas escolas, Araújo e Sales (2011) também confirmaram, por meio de entrevista, que os bibliotecários julgam possuir essa capacidade de promoção e incentivo à leitura. A capacidade de fomentar a interação entre a biblioteca e os diversos tipos de usuários, capacidade de identificar demandas sociais de informação e a capacidade de 
promover a inclusão social foram consideradas totalmente relevantes por $50 \%$ dos bibliotecários.

Tabela 17: Competências sociais e políticas.

\begin{tabular}{l|c|c|c|c|c|c|c}
\hline \multicolumn{1}{c}{ RELEVÂNCIA } & & & & & & \\
\hline
\end{tabular}

Fonte: a autora.

Considera-se, entretanto, que todos os itens elencados na tabela 17 possuem alto grau de pertinência ao mapeamento de competências dos bibliotecários, uma vez que ao somar os resultados obtidos nas alternativas "muito relevante" e "totalmente relevante" é possível obter, conforme apresentado na tabela 17 , percentuais acima de $50 \%$ de relevância. 
Deste modo, os resultados alusivos às competências sociais e políticas apresentados na tabela 17 reforçam a ideia de Mueller (1989), quando a autora menciona a função social do bibliotecário nos campos de preservação da cultura humana, suporte à educação formal e promoção à pesquisa científica; e de Cunha (2003), quando exprime que a profissão do bibliotecário está imersa em uma atuação de mediação e de contato e que, além disso, caracteriza-se como uma profissão essencialmente social.

Contudo, apesar de considerarem relevantes as competências sociais e políticas, percebe-se, ao verificar os dados apresentados na tabela 10, que os bibliotecários não estão devidamente capacitados para o desenvolvimento dessas competências, tendo em vista que, dentre todos os respondentes, apenas $21 \%$ possuem cursos de capacitação em ações culturais/pedagógicas, 29\% em cursos sobre acessibilidade e apenas 7\% realizaram cursos na área de inclusão social. 


\section{CONCLUSÕES DO ESTUDO}

O presente estudo apresentou, como objetivo geral, mapear as competências dos bibliotecários que atuam na rede federal de educação profissional e tecnológica do Distrito Federal. Para o alcance dessa finalidade, estabeleceram-se os seguintes objetivos específicos:

a) mapear as competências necessárias ao desenvolvimento das atividades profissionais, segundo a percepção dos bibliotecários que atuam na Rede Federal de Educação Profissional e Tecnológica do Distrito Federal;

b) verificar se as competências mapeadas estão em conformidade com as estratégias, planos e atribuições da instituição à qual os bibliotecários estão vinculados; e

c) identificar o perfil do bibliotecário que atua na Rede Federal de Educação Profissional e Tecnológica do Distrito Federal.

Os itens a seguir, apresentam, de forma detalhada, os resultados que foram obtidos a partir do estabelecimento desses objetivos específicos, para a realização do propósito geral dessa pesquisa.

\subsection{MAPEAMENTO DAS COMPETÊNCIAS DOS BIBLIOTECÁRIOS DO IFB}

O primeiro objetivo específico desta pesquisa (mapear as competências necessárias ao desenvolvimento das atividades profissionais, segundo a percepção dos bibliotecários que atuam na Rede Federal de Educação Profissional e Tecnológica do Distrito Federal ) pretendeu diagnosticar quais eram as competências que os bibliotecários do IFB julgavam necessárias para o efetivo cumprimento de suas atribuições enquanto profissionais da rede federal de educação profissional e tecnológica do Distrito Federal.

Para a consecução desse objetivo, foi necessária uma pesquisa documental, que permitisse identificar, tanto na literatura sobre as competências profissionais e aquelas inerentes ao bibliotecário, quanto em documentos que evidenciassem em qual contexto organizacional esses profissionais estavam inseridos e quais as suas atribuições. 
A partir da pesquisa documental, foram elaborados instrumentos de coleta de dados, os quais possibilitaram a realização do mapeamento das competências, divididos em quatro eixos temáticos, conforme apresentado no quadro 9.

Quadro 9 - Competências mapeadas.

\begin{tabular}{|c|c|}
\hline \multicolumn{2}{|c|}{ MAPEAMENTO DAS COMPETÊNCIAS DOS BIBLIOTECÁRIOS QUE ATUAM NO IFB } \\
\hline $\begin{array}{c}\text { Competências em Comunicação } \\
\text { e Expressão }\end{array}$ & $\begin{array}{l}\text { - Capacidade de comunicação e interação com os } \\
\text { usuários da informação; } \\
\text { - Capacidade de orientar os usuários para um melhor } \\
\text { uso dos recursos de informação; } \\
\text { - Capacidade de disseminação dos produtos e serviços } \\
\text { oferecidos pela biblioteca. }\end{array}$ \\
\hline $\begin{array}{l}\text { Competências Técnico- } \\
\text { Científicas }\end{array}$ & $\begin{array}{l}\text { - } \quad \text { Capacidade de utilizar e disseminar fontes, produtos e } \\
\text { - } \quad \text { Capursos de informação, em diferentes suportes; } \\
\text { - } \quad \text { Ce informação; } \\
\text { - Capacidade de elaborar produtos de informação; } \\
\text { - Capacidade de utilizar recursos de acessibilidade; } \\
\text { informação. }\end{array}$ \\
\hline Competências Gerenciais & 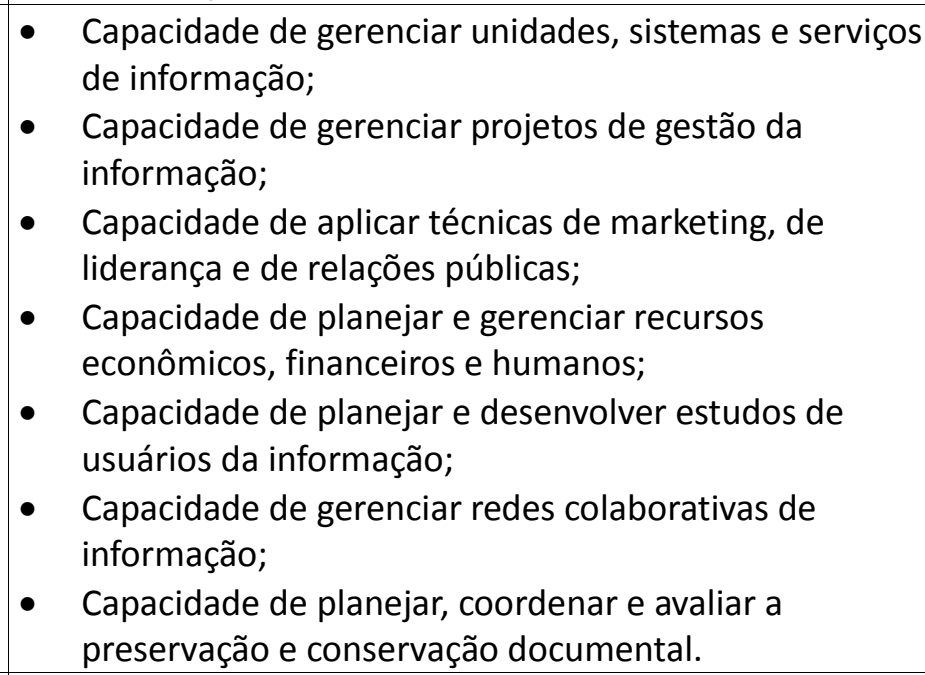 \\
\hline $\begin{array}{c}\text { Competências Sociais e } \\
\text { Políticas }\end{array}$ & $\begin{array}{l}\text { - Capacidade de promover ações de incentivo à leitura e } \\
\text { à pesquisa científica; } \\
\text { - Capacidade de fomentar a interação entre a biblioteca } \\
\text { - } \quad \text { os diversos tipos de usuários; } \\
\text { informação; } \\
\text { - Capacidade de promover a inclusão social; } \\
\text { - Capacidade de formular políticas de preservação do } \\
\text { acervo e da memória institucional. }\end{array}$ \\
\hline
\end{tabular}

Fonte: a autora. 
Em relação ao mapeamento das competências em comunicação e expressão, observa-se a alta relevância atribuída às capacidades de orientação, comunicação e interação com os usuários, além da capacidade de disseminação dos produtos da biblioteca. Verifica-se, portanto, que as competências em comunicação e expressão dos bibliotecários do IFB estão relacionadas, diretamente, ao serviço de referência e ratificam o posicionamento de Araújo e Dias (2005). Segundo esses autores, dentre as competências exigidas do bibliotecário na sociedade da informação, está a função de dinamização da informação, a qual está associada ao serviço de referência e exige do profissional a busca pela educação continuada, com o objetivo de antecipar-se às necessidades de informação do usuário.

Essa função de dinamização da informação também é percebida no mapeamento das competências técnico-científicas. A importância atribuída, pelos bibliotecários, à capacidade de domínio das fontes de informação e de disseminação dessas fontes e demais recursos em diferentes suportes, denotam a preocupação desses profissionais com a questão da transferência da informação.

Nessa perspectiva, os bibliotecários também evidenciaram a capacidade de elaborar produtos de informação e utilizar os recursos de tecnologia da informação. Essas capacidades também indicam a atenção dispensada à questão da disseminação, já que possibilitam aos profissionais criar condições para viabilizar o fluxo de informações no ambiente do IFB.

A percepção dos bibliotecários do IFB no tocante às competências gerenciais salienta a importância de possuir habilidades de gestão em unidades de informação direcionadas à gestão de projetos, recursos humanos e financeiros, além das capacidades relacionadas à gestão e preservação do acervo das bibliotecas. No âmbito do IFB, o desenvolvimento de competências gerenciais revela-se, de fato, necessário, tendo em vista que, conforme os resultados desta pesquisa, quase a metade dos bibliotecários da instituição atua em atividades de gestão. 
As competências sociais e políticas mapeadas revelam a significância atribuída pelos bibliotecários à função social das bibliotecas em relação à comunidade atendida pelo IFB. Capacidades relacionadas à promoção da leitura e da pesquisa, relacionamento entre a biblioteca e seu usuário e fomento à inclusão social simbolizam que os bibliotecários do IFB, apesar de relatar que desempenham funções eminentemente técnicas, preocupam-se, também, com o seu dever enquanto profissional que atua em contexto educacional, federal e público.

\subsection{VERIFICAÇÃO DA CONFORMIDADE DAS COMPETÊNCIAS MAPEADAS}

O segundo objetivo específico deste estudo pretendeu verificar se as competências mapeadas estão em conformidade com as estratégias, planos e atribuições da instituição à qual os bibliotecários estão vinculados. Para tanto, foi realizada uma pesquisa documental, que possibilitou examinar quais eram os objetivos institucionais, missão, visão e valores do IFB, além das atribuições atinentes ao sistema de bibliotecas dessa instituição.

O quadro 10 apresenta a relação entre as competências mapeadas e as estratégias, planos e atribuições do IFB.

Quadro 10 - Comparativo entre as competências dos bibliotecários e as estratégias, planos e atribuições do IFB.

\begin{tabular}{|c|c|}
\hline COMPETÊNCIA MAPEADA & ESTRATÉGIAS, PLANOS E ATRIBUIÇÕES DO IFB \\
\hline \multicolumn{2}{|l|}{ Competências em Comunicação e Expressão } \\
\hline $\begin{array}{l}\text { Capacidade de orientar os usuários para } \\
\text { um melhor uso dos recursos de informação }\end{array}$ & $\begin{array}{l}\text { Atender a comunidade acadêmica e o } \\
\text { público em geral, prestando serviços } \\
\text { informacionais e bibliográficos que } \\
\text { contribuam ao desenvolvimento dos } \\
\text { programas de ensino, pesquisa e extensão } \\
\text { do IFB e para a socialização da cultura. }\end{array}$ \\
\hline $\begin{array}{l}\text { Capacidade de disseminação dos produtos } \\
\text { e serviços oferecidos pela biblioteca }\end{array}$ & $\begin{array}{l}\text { Suprir a comunidade acadêmica com } \\
\text { metodologias, informações e serviços para } \\
\text { a produção, disseminação e uso da } \\
\text { informação disponível no acervo e em } \\
\text { outras fontes e instituições. }\end{array}$ \\
\hline & Continua... \\
\hline
\end{tabular}

Fonte: a autora. 
Quadro 10 - Comparativo entre as competências dos bibliotecários e as estratégias, (Cont.) planos e atribuições do IFB.

\begin{tabular}{|c|c|}
\hline Competências Técnico-Científicas & \\
\hline $\begin{array}{l}\text { Capacidade de utilizar e disseminar } \\
\text { fontes, produtos e recursos de } \\
\text { informação, em diferentes suportes }\end{array}$ & $\begin{array}{l}\text { - Disponibilizar a informação através da localização } \\
\text { e recuperação de informações; } \\
\text { - Disseminar informação. }\end{array}$ \\
\hline $\begin{array}{l}\text { Capacidade de pesquisa e domínio } \\
\text { das diversas fontes de informação }\end{array}$ & - Gerenciar fontes de informação. \\
\hline $\begin{array}{l}\text { Capacidade de elaborar produtos de } \\
\text { informação }\end{array}$ & $\begin{array}{l}\text { - Desenvolver e gerenciar bases de dados } \\
\text { bibliográficos; } \\
\text { - Desenvolver metodologias para geração de } \\
\text { documentos digitais ou eletrônicos; } \\
\text { - Coordenar e desenvolver bibliotecas virtuais e } \\
\text { digitais; } \\
\text { - Desenvolver programas de extensão e de } \\
\text { divulgação científica e tecnológica. }\end{array}$ \\
\hline $\begin{array}{l}\text { Capacidade de utilizar recursos da } \\
\text { tecnologia da informação }\end{array}$ & $\begin{array}{l}\text { - Prestar atendimento personalizado e serviços de } \\
\text { informação on-line; } \\
\text { - Automatizar unidades de informação; } \\
\text { - Assessorar o desenvolvimento de interfaces de } \\
\text { serviços informatizados. }\end{array}$ \\
\hline \multicolumn{2}{|l|}{ Competências Gerenciais } \\
\hline $\begin{array}{l}\text { Capacidade de gerenciar unidades, } \\
\text { sistemas e serviços de informação }\end{array}$ & $\begin{array}{l}\text { Gerenciar recursos de informação e elaborar } \\
\text { políticas de funcionamento para a biblioteca, } \\
\text { programas e projetos de ação, manuais de } \\
\text { serviços, procedimentos e relatórios. }\end{array}$ \\
\hline $\begin{array}{l}\text { Capacidade de gerenciar projetos de } \\
\text { gestão da informação }\end{array}$ & $\begin{array}{l}\text { Desenvolver políticas de informação e padrões } \\
\text { de qualidade gerencial e implementar padrões de } \\
\text { qualidade }\end{array}$ \\
\hline $\begin{array}{l}\text { Capacidade de aplicar técnicas de } \\
\text { marketing, de liderança e de relações } \\
\text { públicas }\end{array}$ & $\begin{array}{l}\text { Promover a divulgação e o reconhecimento dos } \\
\text { serviços das bibliotecas por meio de estratégias } \\
\text { de marketing. }\end{array}$ \\
\hline $\begin{array}{l}\text { Capacidade de gerenciar redes } \\
\text { colaborativas de informação }\end{array}$ & $\begin{array}{l}\text { Estabelecer parcerias com bibliotecas e } \\
\text { entidades de interesse comum ao das áreas de } \\
\text { atuação dos campi, com vistas ao intercâmbio de } \\
\text { informações e desenvolvimento de projetos; } \\
\text { - Implementar atividades cooperativas entre as } \\
\text { instituições; } \\
\text { - Administrar o compartilhamento de recursos } \\
\text { informacionais. }\end{array}$ \\
\hline $\begin{array}{l}\text { Capacidade de planejar, coordenar e } \\
\text { avaliar a preservação e conservação } \\
\text { documental }\end{array}$ & $\begin{array}{l}\text { - Realizar o inventário dos materiais bibliográficos; } \\
\text { - Desenvolver e executar planos de conservação, } \\
\text { restauração e proteção do patrimônio da } \\
\text { biblioteca. } \\
\text { Continua... }\end{array}$ \\
\hline
\end{tabular}

Fonte: a autora. 
Quadro 10 - Comparativo entre as competências dos bibliotecários e as estratégias, planos e atribuições do IFB.

(cont.)

\begin{tabular}{|c|c|}
\hline Competências Sociais e Políticas & \\
\hline $\begin{array}{l}\text { Capacidade de promover ações de } \\
\text { incentivo à leitura e à pesquisa científica }\end{array}$ & $\begin{array}{l}\text { - Constituir-se em centro de excelência na } \\
\text { oferta do ensino de ciências em geral, e de } \\
\text { ciências aplicadas, em particular, } \\
\text { estimulando o desenvolvimento de espírito } \\
\text { crítico, voltado à investigação empírica; } \\
\text { - Realizar e estimular a pesquisa aplicada, a } \\
\text { produção cultural, o empreendedorismo, o } \\
\text { cooperativismo e o desenvolvimento } \\
\text { científico e tecnológico; } \\
\text { - Realizar difusão cultural, promovendo } \\
\text { atividades de fomento à leitura. }\end{array}$ \\
\hline $\begin{array}{l}\text { Capacidade de identificar demandas sociais } \\
\text { de informação }\end{array}$ & $\begin{array}{l}\text { Desenvolver a educação profissional e } \\
\text { tecnológica como processo educativo e } \\
\text { investigativo de geração e adaptação de } \\
\text { soluções técnicas e tecnológicas às } \\
\text { demandas sociais e peculiaridades } \\
\text { regionais. }\end{array}$ \\
\hline Capacidade de promover a inclusão social & $\begin{array}{l}\text { Oferecer ensino, pesquisa e extensão no } \\
\text { âmbito da Educação Profissional e } \\
\text { Tecnológica, por meio da inovação, } \\
\text { produção e difusão de conhecimentos, } \\
\text { contribuindo para a formação cidadã e o } \\
\text { desenvolvimento sustentável, } \\
\text { comprometidos com a dignidade humana e } \\
\text { a justiça social; } \\
\text { - Promoção da inclusão. }\end{array}$ \\
\hline $\begin{array}{l}\text { Capacidade de formular políticas de } \\
\text { preservação do acervo e da memória } \\
\text { institucional }\end{array}$ & $\begin{array}{l}\text { - Preservar e organizar a memória } \\
\text { institucional, de acordo com a Política de } \\
\text { Desenvolvimento de Coleções do IFB. }\end{array}$ \\
\hline
\end{tabular}

Fonte: a autora.

Nota-se, a partir da observação do quadro 10, que a maioria das competências mapeadas está relacionada a uma ou mais atribuições, estratégias e/ou planos do IFB. Verifica-se, também, que o maior número de relacionamentos está ligado às competências técnicas, ratificando, mais uma vez, a importância dessas competências para o desempenho das funções que os bibliotecários consideraram preponderantes. 
Competências técnicas relacionadas à capacidade de pesquisa foram mapeadas dentre aquelas consideradas necessárias para a atuação do bibliotecário no IFB e também constam no regulamento do sistema de bibliotecas dentre as atribuições desses profissionais. Contudo, apesar de considerarem a capacidade de pesquisa relevante para a aquisição de competências técnicas, os bibliotecários afirmam que não exercem a função de pesquisador na instituição. Destarte, foi identificado, a partir da comparação entre as estratégias, planos e atribuições do IFB e as competências mapeadas nesse estudo, o que Brandão e Bahry (2005) denominaram gap ou lacuna de competências, visto que dentre as atribuições do sistema de bibliotecas do IFB está previsto

[...] atender a comunidade acadêmica e o público em geral, prestando serviços informacionais e bibliográficos que contribuam ao desenvolvimento dos programas de ensino, pesquisa e extensão do IFB e para a socialização da cultura (BRASIL. MINISTÉRIO DA EDUCAÇÃO, 2014c, p. 1).

As competências em comunicação e expressão relacionam-se aos propósitos institucionais do IFB de viabilizar o atendimento e serviços de informação de qualidade. Para isso, é necessário que o bibliotecário desenvolva habilidades concernentes às práticas de boa comunicação e interação com o público, além de aperfeiçoamento em serviços relacionados à disseminação da informação. Logo, é possível constatar, nessa pesquisa, que os bibliotecários estão conscientes dessas demandas e, por esse motivo, as consideraram relevantes.

Conforme os dados apresentados na tabela 10 , as competências gerencias estão associadas às práticas de gestão nas bibliotecas do IFB, como por exemplo: gerenciamento de recursos de informação, planejamento de políticas e projetos relacionados à gestão da informação, ações de marketing, administração de redes de compartilhamento de informações, além da gestão patrimonial. Compreende-se, deste modo, o nível elevado de relevância atribuído a essas competências pelos bibliotecários, levando em consideração a quantidade expressiva de atividades de gestão que são atribuídas a esses profissionais. 
Ao cotejar os dados referentes às estratégias, planos e atribuições do IFB, com as competências sociais e políticas mapeadas, constantes ainda no quadro 10, observa-se, novamente, a função social que deve ser desempenhada pelo bibliotecário que atua nessa instituição. Assim sendo, corrobora-se a importância atribuída pelos bibliotecários às competências relacionadas às ações de difusão da informação e incentivo à leitura, à articulação da interação entre a biblioteca e seus usuários, à promoção da inclusão social e à preservação da memória institucional.

\subsection{IDENTIFICAÇÃO DO PERFIL DOS BIBLIOTECÁRIOS QUE ATUAM NO IFB}

Identificar o perfil do bibliotecário que atua na Rede Federal de Educação Profissional e Tecnológica do Distrito Federal é a proposta referente ao terceiro objetivo específico desta pesquisa. Para o alcance desse propósito, foram realizados os mesmos métodos e procedimentos de coleta de dados utilizados no mapeamento de competências dos bibliotecários e detalhados no item 4 do presente estudo.

O quadro 11 retrata uma síntese dos dados obtidos a partir do questionário aplicado e respondido pelos bibliotecários que atuam no IFB.

Quadro 11 - Perfil dos bibliotecários que atuam no IFB.

\begin{tabular}{|l|l|l|}
\hline \multicolumn{3}{|c|}{ PERFIL DOS BIBLIOTECÁRIOS QUE ATUAM NO IFB } \\
\hline $\begin{array}{l}\text { Tempo de atuação do } \\
\text { bibliotecário no IFB }\end{array}$ & 2 a 4 anos \\
\hline $\begin{array}{l}\text { Tempo de formado em } \\
\text { Biblioteconomia }\end{array}$ & 6 a 8 anos \\
\hline $\begin{array}{l}\text { Tempo de atuação como } \\
\text { bibliotecário }\end{array}$ & 6 a 8 anos & \\
\hline $\begin{array}{l}\text { Faixa etária } \\
\text { Sexo predominante }\end{array}$ & $\begin{array}{l}\text { Feminino } 35 \text { anos } \\
\text { Formação } \\
\text { complementar }\end{array}$ & $\begin{array}{l}\text { Segunda graduação; curso de especialização; curso de } \\
\text { mestrado. }\end{array}$ \\
\hline
\end{tabular}

Fonte: a autora. 
Quadro 11 - Perfil dos bibliotecários que atuam no IFB.

(Cont.)

\begin{tabular}{|c|c|}
\hline $\begin{array}{l}\text { Conhecimento em } \\
\text { idiomas }\end{array}$ & $\begin{array}{l}\text { - Espanhol: conhecimento básico; } \\
\text { - Inglês: conhecimento básico; } \\
\text { - Francês: não possui conhecimento; } \\
\text { - Outros Idiomas: não possui conhecimento. }\end{array}$ \\
\hline Faixa salarial & $\mathrm{R} \$ 3.001,00$ a $\mathrm{R} \$ 6.000,00$ \\
\hline $\begin{array}{l}\text { Áreas de atuação no } \\
\text { sistema de bibliotecas } \\
\text { do IFB }\end{array}$ & $\begin{array}{l}\text { - } \text { Circulação de materiais; } \\
\text { - } \quad \text { Coordenação de Sistema de Bibliotecas; } \\
\text { - Gestão de Unidade de Informação; } \\
\text { - Processamento técnico; } \\
\text { - Serviço de referência. }\end{array}$ \\
\hline $\begin{array}{l}\text { Características que o } \\
\text { bibliotecário deve } \\
\text { possuir para atuar no } \\
\text { IFB }\end{array}$ & $\begin{array}{l}\text { - Bom relacionamento interpessoal; } \\
\text { - Espírito crítico; } \\
\text { - Proatividade; } \\
\text { - Saber comunicar-se; } \\
\text { - Saber trabalhar em equipe. }\end{array}$ \\
\hline $\begin{array}{l}\text { Cursos de capacitação } \\
\text { realizados pela maioria } \\
\text { dos bibliotecários do IFB }\end{array}$ & $\begin{array}{l}\text { - Atendimento ao usuário / serviço de referência; } \\
\text { - Catalogação; } \\
\text { - Classificação. }\end{array}$ \\
\hline $\begin{array}{l}\text { Cursos de capacitação } \\
\text { desejáveis ao } \\
\text { bibliotecário que Atua } \\
\text { no IFB }\end{array}$ & $\begin{array}{l}\text { - Acessibilidade; } \\
\text { - Ações culturais; } \\
\text { - Atendimento ao usuário / serviço de referência; } \\
\text { - Automação de bibliotecas; } \\
\text { - Bibliotecas digitais; } \\
\text { - Catalogação; } \\
\text { - Classificação; } \\
\text { - Desenvolvimento de coleções; } \\
\text { - Gerenciamento de unidades de informação; } \\
\text { - Indexação; } \\
\text { - Liderança e motivação no trabalho; } \\
\text { - Normas técnicas; } \\
\text { - Relacionamento interpessoal; } \\
\text { - Técnicas de negociação e resolução de conflitos; } \\
\text { - Tecnologia da Informação. }\end{array}$ \\
\hline $\begin{array}{l}\text { Fatores que } \\
\text { influenciaram o } \\
\text { bibliotecário a seguir } \\
\text { carreira no IFB }\end{array}$ & $\begin{array}{l}\text { - Estabilidade no emprego; } \\
\text { - Horário flexível; } \\
\text { - Identificação com a filosofia da instituição; } \\
\text { - Possibilidade de aplicar o conhecimento adquirido. }\end{array}$ \\
\hline
\end{tabular}

Fonte: a autora. 
A partir da análise da literatura pesquisada e dos dados coletados e tabulados foi possível delinear o perfil do bibliotecário que atua no IFB. Além dos dados apresentados no quadro 11, cabe ressaltar mais algumas informações relevantes para a composição do perfil desses profissionais.

É importante salientar que, embora a pesquisa tenha revelado uma população de bibliotecários jovens, a maioria desses profissionais tem experiência em bibliotecas ligadas ao ensino e, inclusive, uma parcela dos bibliotecários que estão trabalhando no IFB (16\%) já possui experiência em bibliotecas da rede federal de ensino de outro estado.

Outro ponto que chamou a atenção foi o nível de qualificação dos bibliotecários. Observou-se a preocupação desses respondentes em buscar o aperfeiçoamento profissional e a educação continuada. Quase $80 \%$ deles possuem pós-graduação lato sensu e a grande maioria afirmou que pretende cursar o mestrado e o doutorado.

Os resultados desse estudo também retratam os bibliotecários como profissionais polivalentes, já que atuam em várias frentes de trabalho nas bibliotecas do IFB e buscam qualificação e capacitação profissional em áreas multidisciplinares do conhecimento.

Entretanto, em referência aos cursos de capacitação, percebe-se uma deficiência entre os que foram efetivamente realizados e aqueles que são necessários ao desempenho das atividades dos bibliotecários, tendo em vista as estratégias, planos e atribuições do IFB. Nota-se uma preocupação maior no tocante à capacitação voltada ao trabalho técnico, mas, contudo, o presente estudo identificou a pertinência do aperfeiçoamento profissional também em relação ao desenvolvimento de competências gerenciais, de comunicação e expressão, além das competências sociais e políticas.

O conhecimento em idiomas é considerado outro fator que possui um grau de competência inferior ao que seria desejável ao bibliotecário que atua no IFB, considerando que a instituição oferece cursos superiores e de curta duração em língua inglesa e espanhola e o resultado dessa pesquisa apontou que os 
respondentes, de modo geral, possuem apenas o conhecimento básico das línguas espanhola, inglesa e francesa e não possuem conhecimento algum em outros idiomas.

\subsection{CONSIDERAÇÕES FINAIS E SUGESTÕES DE PESQUISAS FUTURAS}

O presente estudo teve como propósito geral mapear as competências dos bibliotecários que atuam na rede federal de educação profissional e tecnológica do Distrito Federal. Para o alcance dessa finalidade, estabeleceramse os objetivos específicos conforme item 1.3.2.

Para alcançar esses objetivos, foi realizada, inicialmente, uma revisão da literatura sobre "competências", onde foram estudadas as origens do termo e suas definições, sendo que, para essa pesquisa, foram adotados os conceitos que mais se relacionavam ao ambiente organizacional, uma vez que os indivíduos que fazem parte do universo dessa pesquisa, estão inseridos nessa conjuntura. Assim sendo, pesquisou-se sobre os atributos da competência, o desenvolvimento de competências profissionais e individuais, além das competências específicas do profissional da informação.

A partir da compreensão dos conceitos de competência, procedeu-se um estudo sobre o mapeamento de competências, no qual foram identificados os preceitos e finalidades do mapeamento de competências em ambiente organizacional, além de recomendações e metodologias para a identificação de competências nesse contexto. Do mesmo modo, pesquisou-se sobre o mapeamento de competências em unidades de informação, tendo em vista a identificação de modelos e metodologias que auxiliassem na fundamentação teórica e empírica desse trabalho.

Ainda sob o propósito de embasar a presente pesquisa, foi contemplada, na revisão de literatura, uma breve abordagem sobre a sociedade da informação, caracterizando esse paradigma sob os pontos de vista econômico e social, com o objetivo de compreender e identificar qual o perfil do bibliotecário, apontado pelos autores da Ciência da Informação, perante esse cenário. 
Ademais, realizou-se uma pesquisa documental, no intento de localizar documentos relacionados ao histórico da rede federal de educação profissional e tecnológica do Distrito Federal, seus objetivos institucionais, missão, visão e valores, além das atribuições inerentes tanto ao sistema de bibliotecas dessa rede quanto aos bibliotecários que ali atuam. A análise desses documentos permitiu identificar quais as estratégias, planos e atribuições da rede estão diretamente ligados às competências que os bibliotecários julgaram necessárias para o desempenho de suas atividades profissionais.

Com base na revisão de literatura sobre competência, perfil do bibliotecário na sociedade da informação, pesquisa documental sobre a rede federal de educação profissional e tecnológica do Distrito Federal e leitura de textos sobre metodologia científica, foram desenvolvidos procedimentos metodológicos para a coleta e análise dos dados, permitindo, dessa forma, atingir os resultados alcançados nos itens 5 e 6 desse estudo.

As conclusões da pesquisa ratificam a necessidade da investigação sobre as competências do bibliotecário em ambientes organizacionais, já que permitem verificar se, deveras, os conhecimentos adquiridos por esse profissional, ao longo de sua vida acadêmica, estão de acordo com os propósitos da instituição a qual ele está vinculado e/ou existem as chamadas "lacunas de competência", que podem existir tanto em decorrência de pouca ou nenhuma experiência na área de atuação, mas também podem apontar uma deficiência em relação à educação formal que foi dispensada a esse indivíduo.

Pondera-se, portanto, que a presente pesquisa alcançou os objetivos incialmente traçados, visto que mapeou as competências que os bibliotecários do IFB consideraram como necessárias ao desempenho de suas funções na instituição, verificou-se que a maioria das competências mapeadas possui relação direta com os objetivos, estratégias e atribuições da instituição à qual esses profissionais estão vinculados e, outrossim, identificou o perfil desses indivíduos.

Por fim, almeja-se que esta pesquisa possa contribuir para 0 conhecimento sobre as competências do profissional da informação que atua no âmbito educacional, em especial no contexto da rede de educação profissional e 
tecnológica, e sobre o perfil e competências desses profissionais. Espera-se que outras inquietações surjam a partir do conhecimento produzido, levando ao desenvolvimento de pesquisas que envolvam metodologias e modelos para a identificação e aperfeiçoamento de competências de bibliotecários que atuam no segmento de educação profissional e tecnológica; estudos comparativos sobre as competências dos bibliotecários que atuam em instituições de educação científica e aqueles que trabalham na educação profissional; e estudos que contemplem o mapeamento de competências dos bibliotecários que atuam na educação profissional e tecnológica, sob o ponto de vista dos gestores institucionais, pois são temas que carecem de literatura específica. 


\section{REFERÊNCIAS}

ALMEIDA, Neilia Barros Ferreira de; BAPTISTA, Sofia Galvão. Profissional da informação: imagem, perfil e a necessidade de educação continuada. RICl: R.Ibero-amer. Ci. Inf., Brasília, v. 2, n. 2, p. 1-14, ago./dez., 2009.

AMARAL, Roniberto Morato et al. Modelo para o mapeamento de competências em equipes de inteligência competitiva. Ciência da Informação, Brasília, v. 37, n. 2, p. 7-19, maio/ago., 2008.

AMORIM, lara Rodrigues; Amaral, Roberto Morato. Mapeamento de competências em bibliotecas e unidades de informação. Perspectivas em Ciência da Informação, v.16, n.2, p.2-16, abr./jun. 2011.

ARAÚJO, Eliany Alvarenga; DIAS, Guilherme Atayde. A atuação profissional do bibliotecário no contexto da sociedade da informação: os novos espaços de informação. In: OLIVEIRA, Marlene (Coord.). Ciência da Informação e Biblioteconomia: novos conteúdos e espaços de atuação. Belo Horizonte: Ed. UFMG, 2005.

ARAÚJJO, Paula Carina; SALES, Fernanda de. O bibliotecário e a formação de leitores. Revista ACB: Biblioteconomia m Santa Catarina, Florianópolis, v. 16, n. 2, p. 562-578, jul./dez., 2011.

ARRUDA, Maria da Conceição Calmon; MARTELETO, Regina Maria; SOUZA, Donaldo Bello de. Educação, trabalho e o delineamento de novos perfis profissionais: o bibliotecário em questão. Ciência da Informação, v. 29, n. 3, p. 1424, set./dez. 2000.

BAPTISTA, Sofia Galvão. Bibliotecário autônomo versus institucionalizado: carreira, mercado de trabalho e comprometimento organizacional. 1998. 234f. Tese (Doutorado em Ciência da Informação)-Departamento de Ciência da Informação e Documentação, Universidade de Brasília, Brasília, 1998.

BAPTISTA, Sofia Galvão; MUELLER, Suzana Pinheiro Machado. Considerações sobre o mercado de trabalho do bibliotecário. Información, Cultura Y Sociedad. Buenos Aires, n.12, p. 35-50. jan./jul. 2005.

BELLUZZO, Regina Célia Baptista. As competências do profissional da informação nas organizações contemporâneas. Revista Brasileira de Biblioteconomia e Documentação, Nova Série, São Paulo, v.7, n.1, p. 58-73, jan./jun. 2011.

BELLUZZO, Regina Célia Baptista. Da capacitação de recursos humanos em serviços de informação a experiências com educação à distância. $R$. Bras. Biblioteconon. Doc., São Paulo, v. 1. n. 1, p. 23-37, 1999.

BITENCOURT, C. C. A gestão de competências gerenciais: a contribuição da aprendizagem organizacional. 2001. 319f. Tese (Doutorado em Administração)Escola de Administração, Universidade Federal do Rio Grande do Sul, Porto Alegre, 2001. 
BORGES, Maria Alice Guimarães. A compreensão da sociedade da informação. Ciência da Informação, Brasília, v. 29, n. 3, p. 25-32, set./dez. 2000.

BOYATZIS, Richard E. The competente manager: a model for effective performance. New York: Wiley, c1982.

BRANDÃO, Hugo Pena; BAHRY, Carla Patrícia. Gestão por competências: métodos e técnicas para mapeamento de competências. Revista do Serviço Público, Brasília, v. 56, n. 2, p. 179-194, abr./jun. 2005.

BRASIL. Lei no 11.091, de 12 de janeiro de 2005. Dispõe sobre a estruturação do Plano de Carreira dos Cargos Técnico-Administrativos em Educação, no âmbito das Instituições Federais de Ensino vinculadas ao Ministério da Educação, e dá outras providências. Diário Oficial [da] República Federativa do Brasil. Poder Legislativo, Brasília, DF, 13 jan. 2005, Seção 1, p. 1. Disponível em: $<$ htt://www.in.gov.br>. Acesso em 10 jun. 2015.

BRASIL. Lei no 11.892, de 29 de dezembro, de 2008. Institui a Rede Federal de Educação Profissional, Científica e Tecnológica, cria os Institutos Federais de Educação, Ciência e Tecnologia, e dá outras providências. Diário Oficial [da] República Federativa do Brasil. Poder Legislativo, Brasília, DF, 30 dez. 2008, Seção 1, p. 1. Disponível em: <htt://www.in.gov.br>. Acesso em 03 ago. 2013.

BRASIL. MINISTÉRIO DA EDUCAÇÃO. INSTITUTO FEDERAL DE EDUCAÇÃO, CIÊNCIA E TECNOLOGIA DE BRASÍLIA. Indicadores institucionais. Brasília: IFB, 2014a. Disponível em: <http://www.ifb.edu.br/index.php/acesso-ainformacao/acesso-a-informacao/3413>. Acesso em: 5 jun. 2015.

BRASIL. MINISTÉRIO DA EDUCAÇÃO. INSTITUTO FEDERAL DE EDUCAÇÃO, CIÊNCIA E TECNOLOGIA DE BRASÍLIA. Plano de Desenvolvimento Institucional: 2014 a 2018: vigência no e-MEC (recredenciamento da IES): junho/2014 a junho/2019. Brasília, DF: IFB, 2014b. 171 p. Disponível em: <http://www.ifb.edu.br>. Acesso em 02 ago. 2014.

BRASIL. MINISTÉRIO DA EDUCAÇÃO. INSTITUTO FEDERAL DE EDUCAÇÃO, CIÊNCIA E TECNOLOGIA DE BRASÍLIA. Regulamento do Sistema de Bibliotecas do Instituto Federal de Brasília (SIBIFB): aprovado pela Resolução no 010/2014CS-IFB de 06/05/2014. Brasília, DF: IFB 2014c. 10 p. Disponível em: <http://www.ifb.edu.br>. Acesso em 30 jun. 2014.

BRASIL. MINISTÉRIO DA EDUCAÇÃO. INSTITUTO FEDERAL DE EDUCAÇÃO, CIÊNCIA E TECNOLOGIA DE BRASÍLIA. Resolução nº 007-2013/CS/IFB. Aprova a descrição dos cargos técnico-administrativos em educação, que foram autorizados pelo Ministério de Planejamento, Orçamento e Gestão para concurso público, em conformidade com a Lei ํo 11.091/2005. Brasília, DF, 2013. Disponível em:

http://www.ifb.edu.br/attachments/4736 007 Resolu\%C3\%A7\%C3\%A30\%20desc ri\%C3\%A7\%C3\%A30\%20dos\%20cargos.pdf >. Acesso em 10 jun. 2015. 
BRASIL. MINISTÉRIO DE CIÊNCIA E TECNOLOGIA. Livro verde. Brasília: MCT, 2000.

BUFREM, Leilah S.; PEREIRA, Edmeire C. Os profissionais da informação e a gestão de competências. Perspectivas em Ciência da Informação, Belo Horizonte, v. 9, n. 2, p. 170-181, jul./dez. 2004.

CÂMARA, M. A; BORGES, J. Competências em informação e comunicação: necessidades para participação em redes sociais em ambientes digitais. Revista de Informática Aplicada, São Caetano do Sul, v. 7, n. 2, p. 5-14, jul./dez. 2011.

CARBONE, Pedro Paulo et al. Gestão por competências e gestão do conhecimento. 2. ed. Rio de Janeiro: FGV, 2006.

CASTELLS, Manuel. A sociedade em rede. 5. ed. São Paulo: Paz e Terra, 2001.

CASTRO, César Augusto. Profissional da informação: perfis e atitudes desejadas. Revista Informação \& Sociedade, v. 10, n. 1, 2000. Disponível em: <http://www.informacaoesociedade.ufpb.br/issuev10n100.html>. Acesso em: 16 abr. 2014.

CHAUI, Marilena. A universidade pública sob nova perspectiva. Revista Brasileira de Educação. São Paulo, n. 24, set./dez. 2003.

CORDEIRO, Daniel et al. Da ciência à e-ciência: paradigmas da descoberta do conhecimento. Revista USP, São Paulo, n. 97, p. 71-80, mar./maio. 2013.

COSTA, Maira Murrieta; Cunha, Murilo Bastos. O bibliotecário no tratamento de dados oriundos da e-science: considerações iniciais. Perspectivas em Ciência da Informação, v. 19, n. 3, p. 189-206, jul./set. 2014.

CUNHA, Miriam Vieira. O papel social do bibliotecário. Enc. Bibli: R. Eletr. Bibliotecon. Ci. Inf., Florianópolis, n. 15, 1 sem. 2003.

DIB, Simone Faury Dib; SILVA, Neusa Cardim. Competências em unidades de informação: metodologia para o desenvolvimento de equipes. Perspectivas em Ciência da Informação, v. 14, n. 2, p. 17-29, maio/ago. 2009.

DUARTE, Eizabeth Andrade; Braga, Rogério Manoel de Oliveira. O profissional bibliotecário e o domínio da língua inglesa. Enc. Bibli: R. Eletr. Bibliotecon. Ci. Inf. Florianópolis, v. 15, n. 3, p. 105-122, 2010. Disponível em: < https://periodicos.ufsc.br/index.php/eb/article/view/1518-2924.2010v15n30p105>. Acesso em: 05 jun 2015.

DUTRA, Joel Souza. Competências: conceitos e instrumentos para a gestão de pessoas na empresa moderna. São Paulo: Atlas, 2004.

FARIA, Sueli et al. Competências do profissional da informação: uma reflexão a partir da Classificação Brasileira de Ocupações. Ciência da Informação, Brasília, v. 34, n. 2, p. 26-33, maio/ago. 2005. 
FERREIRA, Maria Mary. O profissional da informação no mundo do trabalho e as relações de gênero. Transinformação, Campinas, v. 15, n. 2, p. 189-201, maio/ago. 2003.

FLEURY, Maria Tereza Leme; FLEURY, Afonso. Construindo o conceito de competência. Rev. adm. contemp., Curitiba, v. 5, n. spe, p. 183-196, 2001.

GUIMARÃES, J. A. C. Moderno profissional da informação: elementos para sua formação no Brasil. Transinformação, v. 9, n.1, p.124-137, 1997.

GOMES, Carlos Eduardo et al. Competências organizacionais e individuais: o que são e como se desenvolvem. In: HANASHIRO, D. M. M.; TEIXEIRA, M. L. M; ZACCARELLI, L. M (Org.). Gestão do fator humano: uma visão baseada em stakeholders. São Paulo: Saraiva, 2007. p. 215-255.

INVERNIZZI, N. Teoria da competência: categorias analíticas e ideologia na compreensão dos novos processos de trabalho. Revista Trabalho \& Educação, Belo Horizonte, v. 9, n. 9, p. 115-131, 2001.

LAZARTE, Leonardo. Ecologia cognitiva na sociedade da informação. Ciência da Informação, Brasília, v. 29, n. 2, p. 43-51, maio/ago. 2000.

LE BOTERF, G. De la compétence: essai sur um attracteur étrange. In: Les éditions d'organisations. Paris: Quatrième Tirage, 1995.

LE BOTERF, G. Desenvolvendo a Competência dos Profissionais. Porto Alegre: Bookman, 2003.

LEFÈVRE, Fernando; LEFÈVRE, Ana Maria Cavalcanti. O discurso do sujeito coletivo: um enfoque em pesquisa qualitativa (desdobramentos). Caxias do Sul, RS: EDUCS, 2003.

LOPEZ DIAZ, M.; PEREZ MATOS, N. E.; REMIGIO, M. C. Identificación de las competencias generales y técnicas necesarias para un mejor desempeño bibliotecario: estudio de un caso. ACIMED [online], v.15, n.1, p. 1-21, 2007. Disponível em: < http://scielo.sld.cu/pdf/aci/v15n1/aci05107.pdf>. Acesso em: 09 maio 2015.

LOUREIRO, M. F.; JANNUZZI, P. M. Profissional da informação: análise da inserção no mercado de trabalho brasileiro. Perspectivas em Ciência da Informação, v. 12, n. 2, p. 23-48, maio/ago. 2007. Disponível em: <http://portaldeperiodicos.eci.ufmg.br/index.php/pci/article/view/46/358>. Acesso em: 24 jul. 2014.

MASON, R. O. What is an information professional? Journal of education for library and information science, v. 31, n. 2, p.122-138, 1990. Disponível em: <http://www.jstor.org/pss/40323396>. Acesso em: 02 jun. 2014.

MCCLELLAND, David C. Testing for competence rather than intelligence. American Psychologist, p. 1-14, jan. 1973. 
MIRABLE, Richard J. Everything you wanted to know about competency modeling. Training \& Development, v. 51, n. 8, aug. 1997.

MOURA, Maria Cristina Canovas; BITENCOURT, Claudia Cristina. A articulação entre estratégia e o desenvolvimento de competências gerenciais. RAEeletrônica, v. 5, n. 1, jan./jun., 2006. Disponível em: <http:// http://www.scielo.br/pdf/raeel/v5n1/29560.pdf>. Acesso em 20 ago. 2014.

MUELLER, Suzana Pinheiro Machado. Perfil do bibliotecário, serviços e responsabilidades na área de informação e formação profissional. Revista de Biblioteconomia de Brasilia, v. 17, n. 1, p. 63-70, jan./jun. 1989.

PARRY, Scott B. The quest for competencies. ABI/Inform Global, v. 33, 7. ed., jul. 1996.

PICCHIAI, Djair. Competências organizacionais, gerenciais e individuais: conceitos e discussões no setor público. Revisa da Micro e Pequena Empresa, v. 4 n. 3, p. 73-89, set./dez. 2010.

RODRIGUES, Dalvanira; MUNIZ, Euzébia Maria de Pontes Targino. Gestão por competências em bibliotecas universitárias. In: SEMINÁRIO NACIONAL DE BIBLIOTECAS UNIVERSITÁRIAS, 16., 2010, Rio de Janeiro. Anais eletrônicos... Rio de Janeiro: UFRJ, $2010 . \quad$ Disponível em: <http://www.sibi.ufrj.br/snbu2010/resumos.html>. Acesso em: 15 set. 2014.

ROSSI, Tatiana; COSTA, Marília Damiani; PINTO, Adilson Luiz. Competências requeridas aos bibliotecários na prestação de serviços de informação em bibliotecas universitárias. Revista ACB: Biblioteconomia em Santa Catarina, Florianópolis, v. 19, n. 1, p. 111-123, jan./jun. 2014.

RUAS, Roberto. Desenvolvimento de competências gerenciais e contribuição da aprendizagem organizacional. In: FLEURY, M. T. L.; OLIVEIRA JR., M. M. (Org.). Gestão estratégica do conhecimento: integrando aprendizagem, conhecimento e competências. São Paulo: Atlas, 2001. p. 242-269.

RUSSO, Mariza. Fundamentos de Biblioteconomia e Ciência da Informação. Rio de Janeiro: E-papers, 2010.

RUZZARIN, Ricardo. Gestão por competências: indo além da teoria. Porto Alegre: SEBRAE/RS, 2002.

RUZZARIN, Ricardo; AMARAL, Augusto Prates; SIMIONOVSCHI, Marcelo. Sistema integrado de gestão de pessoas com base em competências. Porto Alegre: AGE, 2006.

RUZZARIN, Ricardo; SIMIONOVSCHI, Marcelo. Competências: uma base para a governança corporativa. Porto Alegre: AGE, 2010.

SAMPAIO, Larissa Amorim Catunda. Mapeamento das competências gerenciais necessárias aos gerentes das unidades de informação dos Tribunais Superiores do Poder Judiciário Brasileiro, 2010. 224f. Dissertação (mestrado em Ciência da 
Informação)-Departamento de Ciência da Informação e Documentação, Universidade de Brasília, Brasília, 2010.

SANTOS, Jussara Pereira. O moderno profissional da informação: o bibliotecário e seu perfil face aos novos tempos. Informação \& Informação, Londrina, v. 1, n. 1, p. 5-13, jan./jun. 1996.

SILVA, E. L.; CUNHA, M. V. A formação profissional no século XXI: desafios e dilemas. Ciência da Informação, Brasília, v. 31, n. 3, p. 77-82, set./dez. 2002.

SILVEIRA, D. T.; CÓRDONA, F. P. A pesquisa científica. In: GERHARDT, T. E.; SILVEIRA, D. T. (Org.). Métodos de pesquisa. Porto Alegre: Editora da UFRGS, 2009.

SOUZA, Sheila Ataíde Domingues; MOULIN, Maria das Graças Barbosa. Serviço público: significados e sentidos de um trabalho em mutação. Cadernos de Psicologia Social do Trabalho, v. 17, n. 1, p. 49-65, 2014.

SPENCER, Lyle M.; SPENCER, Signe M. Competence at work: models for superior performance. New York: Wiley, 1993.

TARAPANOFF, Kira. O profissional da informação e a sociedade do conhecimento: desafios e oportunidades. Transinformação, Campinas, v. 11, n. 1, p. 27-38, jan./abr. 1999.

TARAPANOFF, Kira et al. Características e tendências do profissional da informação. Revista Brasileira de Biblioteconomia e Documentação, São Paulo, v. 21, n. 3-4, p. 84, jul./dez. 1988.

VALENTIM, Marta Lígia Pomim (Org.) O profissional da informação: formação, perfil e atuação profissional. São Paulo: Polis, 2000.

VENTURA. Magda Maria. O estudo de caso como modalidade de pesquisa. Revista SOCERJ, Rio de Janeiro, v.20, n. 5, p. 383-386, set./out. 2007.

WALTER, Maria Tereza Teles. Bibliotecários no Brasil: representações da profissão. 2008. $345 \mathrm{f}$. Tese (Doutorado em Ciência da Informação)-Departamento de Ciência da Informação e Documentação, Universidade de Brasília, Brasília, 2008.

WERTHEIN, Jorge. A sociedade da informação e seus desafios. Ciência da Informação, Brasília, v. 29, n. 2, p. 71-77, maio/ago. 2000. 
ZARIFIAN, Philippe. O modelo da competência: trajetória histórica, desafios atuais e propostas. São Paulo: Senac, 2003.

ZARIFIAN, Philippe. Objectif compétence. Paris: Liaisons, 1999.

ZARIFIAN, Philippe. Objetivo competência: por uma nova lógica. São Paulo: Atlas, 2001. 


\section{APÊNDICE 1 QUESTIONÁRIO: PERFIL E COMPETÊNCIAS DOS BIBLIOTECÁRIOS QUE ATUAM NA REDE FEDERAL DE ENSINO DO DISTRITO FEDERAL}

Questionário - Perfil e Competências dos Bibliotecários que Atuam na Rede Federal de Ensino Profissional e Tecnológico do Distrito Federal

Caro Bibliotecário,

Sou mestranda em Ciência da Informação na Universidade de Brasília e necessito da sua colaboração no preenchimento do questionário abaixo. Trata-se de uma pesquisa que visa mapear o perfil e as competências dos bibliotecários que atuam na Rede Federal de Ensino Profissional e Tecnológico do Distrito Federal. Sua colaboração é essencial para a coleta de informações sobre os profissionais que atuam neste segmento.

Obrigada pela atenção e desde já agradeço a participação.

Cecília Morena

Bibliotecária

*Obrigatório

Há quanto tempo está atuando nesta Instituição? *

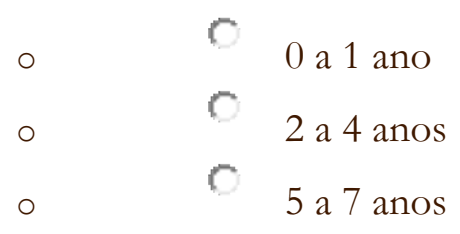

Há quanto tempo formou-se em Biblioteconomia? *

$\begin{array}{ll}\circ & \quad 0 \text { a } 2 \text { anos } \\ \circ & \quad 3 \text { a } 5 \text { anos } \\ \circ & 6 \text { a } 8 \text { anos } \\ \circ & 9 \text { a } 11 \text { anos } \\ \circ & 12 \text { anos ou mais }\end{array}$

Há quanto tempo atua como bibliotecário(a)? *
$\begin{array}{ll}\circ & \quad 0 \text { a } 2 \text { anos } \\ \circ & \text { 3 а } 5 \text { anos } \\ \circ & 6 \text { a } 8 \text { anos } \\ \circ & 9 \text { a } 11 \text { anos } \\ \circ & 12 \text { anos ou mais }\end{array}$ 
Faixa Etária *

Sexo *
$\begin{array}{ll}\circ & \text { Masculino } \\ 0 & \quad \text { Feminino }\end{array}$

Possui formação complementar? *

Marque uma ou mais opções

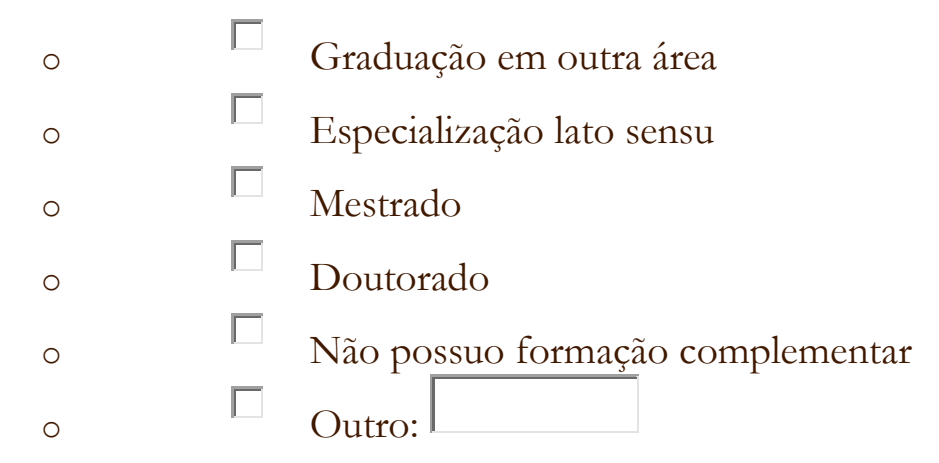

Utilize o espaço abaixo, caso queira complementar a pergunta acima, informando a área do conhecimento em que possui formação complementar.

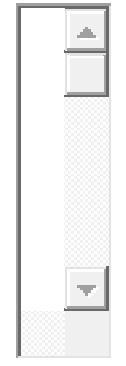

Avalie o seu conhecimento em Idiomas *

\begin{tabular}{|llll}
$\begin{array}{l}\text { Não tenho } \\
\text { conhecimento }\end{array}$ & $\begin{array}{l}\text { Conhecimento } \\
\text { básico }\end{array}$ & $\begin{array}{l}\text { Conhecimento } \\
\text { intermediário }\end{array}$ & $\begin{array}{l}\text { Conhecimento } \\
\text { avançado }\end{array}$ \\
\hline Inglês $\mathrm{O}$ & 0 & 0 & 0 \\
\hline Francês $\mathrm{C}$ & $\mathrm{C}$ & $\mathrm{C}$ & $\mathrm{C}$ \\
\hline Espanholo & $\mathrm{O}$ & $\mathrm{O}$ & $\mathrm{O}$ \\
\hline
\end{tabular}




\begin{tabular}{|llll}
$\begin{array}{l}\text { Não tenho } \\
\text { conhecimento }\end{array}$ & $\begin{array}{l}\text { Conhecimento } \\
\text { básico }\end{array}$ & $\begin{array}{l}\text { Conhecimento } \\
\text { intermediário }\end{array}$ & $\begin{array}{l}\text { Conhecimento } \\
\text { avançado }\end{array}$ \\
\hline $\begin{array}{r}* \text { Outro } \\
\text { Idioma }\end{array}$ & 0 & 0 & \\
\hline
\end{tabular}

*Caso tenha respondido em "Outro Idioma", escreva aqui o nome do idioma

Qual a sua faixa salarial mensal? *

Rendimento bruto.

$\begin{array}{ll}\circ & C \text { Até } \mathrm{R} \$ 1.000,00 \\ \circ & \mathrm{R} \$ 1.001,00 \text { a } 3.000,00 \\ \circ & \mathrm{R} \$ 3.001,00 \text { a } \mathrm{R} \$ 6.000,00 \\ \circ & \mathrm{R} \$ 6.001,00 \text { a } \mathrm{R} \$ 10.000,00 \\ \circ & \text { Acima de } \mathrm{R} \$ 10.000,00\end{array}$

Qual a sua função na Instituição em que atua? *

Marque uma ou mais opções

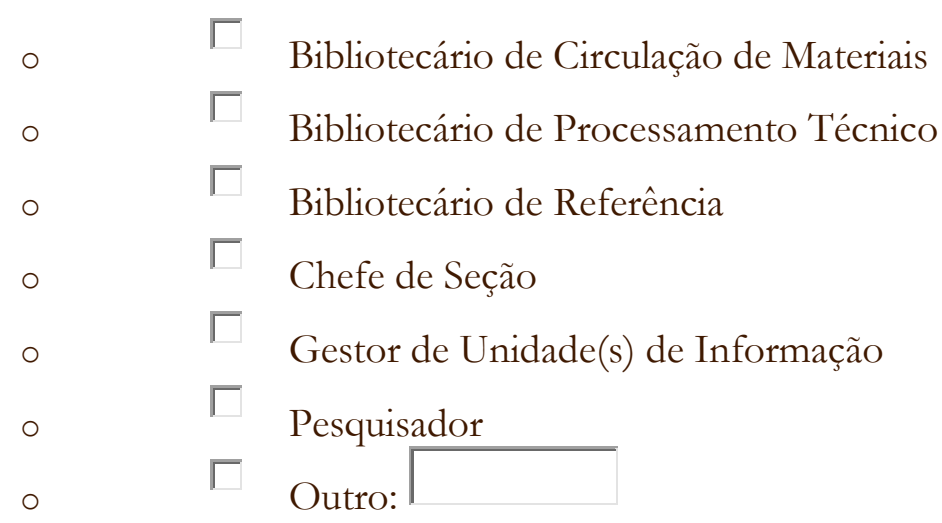

Possui curso(s) de capacitação relacionado(s) com as temáticas abaixo? *

Marque uma ou mais opções

$\begin{array}{lll}\circ & \sqcap & \text { Acessibilidade } \\ \circ & \sqcap & \text { Ações Culturais / Pedagógicas } \\ \circ & \sqcap & \text { Ambientes Virtuais de Aprendizagem / Educação à Distância } \\ \circ & \sqcap & \text { Atendimento ao Usuário / Serviço de Referência } \\ \circ & \sqcap & \text { Automação de Bibliotecas } \\ \circ & \sqcap & \text { Bibliotecas Digitais } \\ \circ & \sqcap & \text { Catalogação }\end{array}$




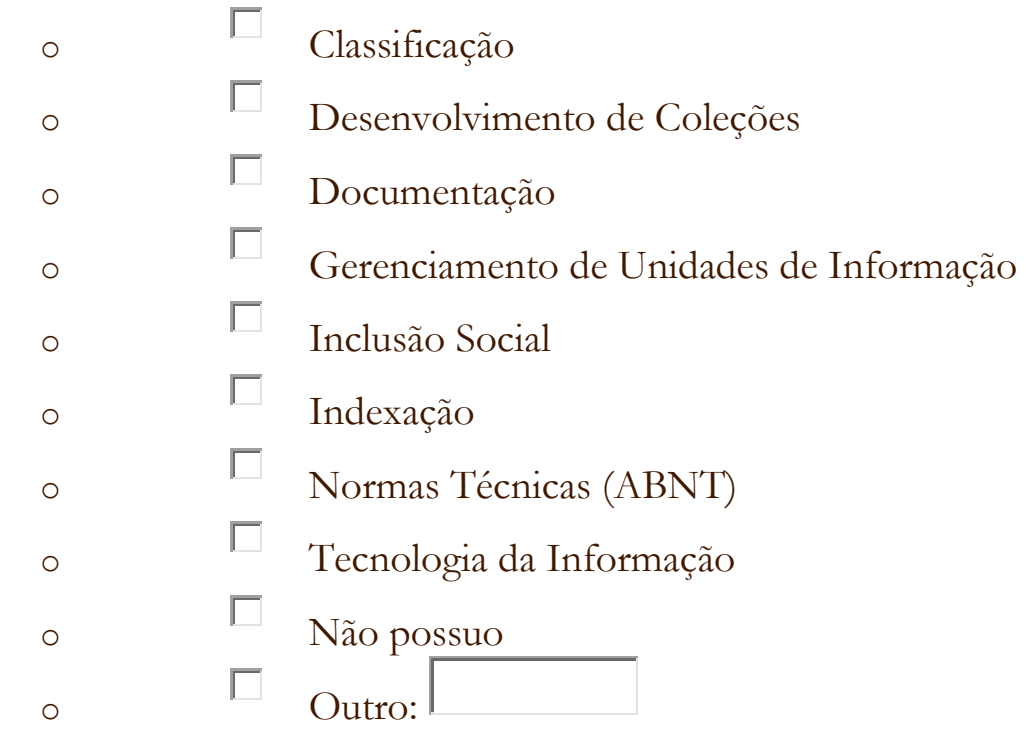

Qual o grau de importância que você atribui, de acordo com a lista abaixo, em relação às características que o bibliotecário deve possuir, para atuar no IFB? * Assinale o grau de relevância pertinente

\begin{tabular}{|c|c|c|c|c|c|}
\hline & $\begin{array}{l}\text { Sem } \\
\text { relevância }\end{array}$ & $\begin{array}{l}\text { Pouco } \\
\text { relevante }\end{array}$ & $\begin{array}{l}\text { Medianamente } \\
\text { relevante }\end{array}$ & $\begin{array}{l}\text { Muito } \\
\text { relevante }\end{array}$ & $\begin{array}{l}\text { Totalmente } \\
\text { relevante }\end{array}$ \\
\hline Proatividade & $C$ & $C$ & $C$ & $C$ & 0 \\
\hline Espírito crítico & 0 & $\mathrm{C}$ & $\mathrm{C}$ & 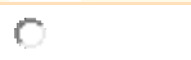 & 0 \\
\hline $\begin{array}{l}\text { Domínio de } \\
\text { uma língua } \\
\text { estrangeira }\end{array}$ & $C$ & $C$ & $C$ & $\mathrm{C}$ & 0 \\
\hline $\begin{array}{l}\text { Bom } \\
\text { relacionamento } \\
\text { interpessoal }\end{array}$ & & $C$ & $C$ & $C$ & 0 \\
\hline $\begin{array}{l}\text { Saber } \\
\text { comunicar-se }\end{array}$ & $C$ & $C$ & 0 & 0 & 0 \\
\hline $\begin{array}{l}\text { Habilidades } \\
\text { pedagógicas }\end{array}$ & $C$ & $c$ & 0 & $c$ & 0 \\
\hline $\begin{array}{l}\text { Saber trabalhar } \\
\text { em equipe }\end{array}$ & 0 & $C$ & 0 & $c$ & 0 \\
\hline
\end{tabular}

Para você, qual a relevância de cursos de capacitação, relacionado(s) às temáticas abaixo, para o aprimoramento das atividades em seu ambiente de trabalho? $*$

Assinale o grau de relevância pertinente
Sem Pouco
Medianamente Muito Totalmente relevância relevante relevante relevante relevante

$\begin{array}{llllll}\text { Acessibilidade } & 0 & 0 & 0 & 0 & 0 \\ \text { Ações Culturais } & 0 & 0 & 0 & 0 & 0\end{array}$




\begin{tabular}{|c|c|c|c|c|c|}
\hline & $\begin{array}{l}\text { Sem } \\
\text { relevância }\end{array}$ & $\begin{array}{l}\text { Pouco } \\
\text { relevante }\end{array}$ & $\begin{array}{l}\text { Medianamente } \\
\text { relevante }\end{array}$ & $\begin{array}{l}\text { Muito } \\
\text { relevante }\end{array}$ & $\begin{array}{l}\text { Totalmente } \\
\text { relevante }\end{array}$ \\
\hline $\begin{array}{l}\text { Ambientes } \\
\text { Virtuais de } \\
\text { Aprendizagem / } \\
\text { Educação à } \\
\text { Distância }\end{array}$ & 0 & 0 & 0 & 0 & 0 \\
\hline $\begin{array}{l}\text { Atendimento ao } \\
\text { Usuário / Serviço } \\
\text { de Referência }\end{array}$ & & 0 & 0 & 0 & 0 \\
\hline $\begin{array}{l}\text { Automação de } \\
\text { Bibliotecas }\end{array}$ & 0 & 0 & $c$ & 0 & $\mathrm{C}$ \\
\hline $\begin{array}{l}\text { Bibliotecas } \\
\text { Digitais }\end{array}$ & 0 & 0 & 0 & 0 & 0 \\
\hline Catalogação & 0 & 0 & 0 & 0 & 0 \\
\hline Classificação & $C$ & 0 & 0 & 0 & 0 \\
\hline $\begin{array}{l}\text { Desenvolvimento } \\
\text { de Coleções }\end{array}$ & 0 & 0 & 0 & 0 & 0 \\
\hline Documentação & $\mathrm{C}$ & $\mathrm{C}$ & $C$ & $\mathrm{C}$ & $C$ \\
\hline $\begin{array}{l}\text { Gerenciamento } \\
\text { de Unidades de } \\
\text { Informação }\end{array}$ & $C$ & 0 & 0 & 0 & 0 \\
\hline Inclusão Social & $\mathrm{C}$ & 0 & 0 & 0 & $\mathrm{C}$ \\
\hline Indexação & 0 & 0 & 0 & 0 & 0 \\
\hline $\begin{array}{l}\text { Liderança e } \\
\text { Motivação no } \\
\text { Trabalho }\end{array}$ & 0 & 0 & $c$ & 0 & 0 \\
\hline $\begin{array}{l}\text { Normas Técnicas } \\
(\mathrm{ABNT})\end{array}$ & 0 & 0 & 0 & 0 & 0 \\
\hline $\begin{array}{l}\text { Relacionamento } \\
\text { Interpessoal }\end{array}$ & $c$ & 0 & $\mathrm{C}$ & $c$ & 0 \\
\hline $\begin{array}{l}\text { Técnicas de } \\
\text { Negociação e } \\
\text { Resolução de } \\
\text { Conflitos }\end{array}$ & 0 & 0 & $c$ & 0 & 0 \\
\hline $\begin{array}{l}\text { Tecnologias da } \\
\text { Informação }\end{array}$ & 0 & 0 & $C$ & 0 & 0 \\
\hline
\end{tabular}

Qual(is) dos itens abaixo o(a) influenciaram na decisão de atuar em biblioteca da Rede Federal de Ensino*

Assinale o grau de relevância pertinente

\begin{tabular}{llllll} 
& $\begin{array}{l}\text { Sem } \\
\text { relevância }\end{array}$ & $\begin{array}{l}\text { Pouco } \\
\text { relevante }\end{array}$ & $\begin{array}{l}\text { Medianamente } \\
\text { relevante }\end{array}$ & $\begin{array}{l}\text { Muito } \\
\text { relevante }\end{array}$ & $\begin{array}{l}\text { Totalmente } \\
\text { relevante }\end{array}$ \\
\hline Autonomia & $\mathrm{C}$ & $\mathrm{C}$ & $\mathrm{C}$ & 0 & 0 \\
\hline
\end{tabular}




\begin{tabular}{|c|c|c|c|c|c|}
\hline & $\begin{array}{l}\text { Sem } \\
\text { relevância }\end{array}$ & $\begin{array}{l}\text { Pouco } \\
\text { relevante }\end{array}$ & $\begin{array}{l}\text { Medianamente } \\
\text { relevante }\end{array}$ & $\begin{array}{l}\text { Muito } \\
\text { relevante }\end{array}$ & $\begin{array}{l}\text { Totalmente } \\
\text { relevante }\end{array}$ \\
\hline $\begin{array}{l}\text { Benefícios } \\
\text { oferecidos }\end{array}$ & $C$ & $C$ & $C$ & 0 & $C$ \\
\hline $\begin{array}{l}\text { Condições de } \\
\text { trabalho }\end{array}$ & 0 & 0 & $C$ & 0 & 0 \\
\hline $\begin{array}{l}\text { Estabilidade } \\
\text { no emprego }\end{array}$ & $c$ & $C$ & 0 & 0 & 0 \\
\hline $\begin{array}{l}\text { Horário- } \\
\text { flexível }\end{array}$ & $\mathrm{C}$ & $C$ & $C$ & 0 & $C$ \\
\hline $\begin{array}{l}\text { Identificou-se } \\
\text { com a } \\
\text { filosofia da } \\
\text { instituição }\end{array}$ & 0 & 0 & 0 & $C$ & 0 \\
\hline $\begin{array}{l}\text { Possibilidade } \\
\text { de aplicar o } \\
\text { conhecimento } \\
\text { adquirido }\end{array}$ & $\mathrm{C}$ & 0 & $C$ & 0 & 0 \\
\hline $\begin{array}{l}\text { Possibilidade } \\
\text { de ascensão } \\
\text { profissional }\end{array}$ & 0 & 0 & $C$ & 0 & $C$ \\
\hline Prestígio & $C$ & $C$ & $C$ & $C$ & $C$ \\
\hline Remuneração & 0 & 0 & 0 & $c$ & 0 \\
\hline
\end{tabular}

Considerando os objetivos da instituição em que você trabalha, avalie o grau de relevância das competências abaixo: Competências no quesito Comunicação e Expressão *

\begin{tabular}{|c|c|c|c|c|c|}
\hline & $\begin{array}{l}\text { Sem } \\
\text { relevância }\end{array}$ & $\begin{array}{l}\text { Pouco } \\
\text { relevante }\end{array}$ & $\begin{array}{l}\text { Medianamente } \\
\text { relevante }\end{array}$ & $\begin{array}{l}\text { Muito } \\
\text { relevante }\end{array}$ & $\begin{array}{l}\text { Totalmente } \\
\text { relevante }\end{array}$ \\
\hline $\begin{array}{l}\text { Capacidade } \\
\text { de orientar } \\
\text { os usuários } \\
\text { para um } \\
\text { melhor uso } \\
\text { dos recursos } \\
\text { de } \\
\text { informação }\end{array}$ & $C$ & $C$ & 0 & $\sigma$ & 0 \\
\hline $\begin{array}{l}\text { Capacidade } \\
\text { de } \\
\text { comunicação } \\
\text { e interação } \\
\text { com os } \\
\text { usuários da } \\
\text { informação }\end{array}$ & 0 & 0 & 0 & 0 & $C$ \\
\hline $\begin{array}{l}\text { Capacidade } \\
\text { de }\end{array}$ & $C$ & 0 & 0 & 0 & $C$ \\
\hline
\end{tabular}




\begin{tabular}{|c|c|c|c|c|c|}
\hline & $\begin{array}{l}\text { Sem } \\
\text { relevância }\end{array}$ & $\begin{array}{l}\text { Pouco } \\
\text { relevante }\end{array}$ & $\begin{array}{l}\text { Medianamente } \\
\text { relevante }\end{array}$ & $\begin{array}{l}\text { Muito } \\
\text { relevante }\end{array}$ & $\begin{array}{l}\text { Totalmente } \\
\text { relevante }\end{array}$ \\
\hline $\begin{array}{l}\text { comunicação } \\
\text { e interação } \\
\text { com os } \\
\text { demais } \\
\text { servidores da } \\
\text { biblioteca }\end{array}$ & & & & & \\
\hline $\begin{array}{l}\text { Capacidade } \\
\text { de } \\
\text { disseminação } \\
\text { da } \\
\text { informação }\end{array}$ & & $C$ & 0 & $C$ & 0 \\
\hline $\begin{array}{l}\text { Capacidade } \\
\text { de } \\
\text { disseminação } \\
\text { de produtos } \\
\text { e serviços } \\
\text { oferecidos } \\
\text { pela } \\
\text { biblioteca }\end{array}$ & 0 & $C$ & 0 & $C$ & 0 \\
\hline
\end{tabular}

\section{Competências Técnico-Científicas *}

\begin{tabular}{|c|c|c|c|c|c|}
\hline & $\begin{array}{l}\text { Sem } \\
\text { relevância }\end{array}$ & $\begin{array}{l}\text { Pouco } \\
\text { relevante }\end{array}$ & $\begin{array}{l}\text { Medianamente } \\
\text { relevante }\end{array}$ & $\begin{array}{l}\text { Muito } \\
\text { relevante }\end{array}$ & $\begin{array}{l}\text { Totalmente } \\
\text { relevante }\end{array}$ \\
\hline $\begin{array}{l}\text { Capacidade de } \\
\text { desenvolver e } \\
\text { executar o } \\
\text { processamento } \\
\text { de documentos } \\
\text { em distintos } \\
\text { suportes }\end{array}$ & 0 & 0 & $C$ & 0 & 0 \\
\hline $\begin{array}{l}\text { Capacidade de } \\
\text { selecionar e } \\
\text { difundir a } \\
\text { informação } \\
\text { gravada em } \\
\text { qualquer meio } \\
\text { para os usuários }\end{array}$ & $C$ & 0 & 0 & 0 & 0 \\
\hline $\begin{array}{l}\text { Capacidade de } \\
\text { elaborar } \\
\text { produtos de } \\
\text { informação }\end{array}$ & 0 & 0 & $C$ & 0 & 0 \\
\hline $\begin{array}{l}\text { Capacidade de } \\
\text { utilizar e } \\
\text { disseminar } \\
\text { fontes, produtos } \\
\text { e recursos de }\end{array}$ & 0 & 0 & $C$ & 0 & 0 \\
\hline
\end{tabular}




\begin{tabular}{|c|c|c|c|c|c|}
\hline & $\begin{array}{l}\text { Sem } \\
\text { relevância }\end{array}$ & $\begin{array}{l}\text { Pouco } \\
\text { relevante }\end{array}$ & $\begin{array}{l}\text { Medianamente } \\
\text { relevante }\end{array}$ & $\begin{array}{l}\text { Muito } \\
\text { relevante }\end{array}$ & $\begin{array}{l}\text { Totalmente } \\
\text { relevante }\end{array}$ \\
\hline $\begin{array}{l}\text { informação em } \\
\text { diferentes } \\
\text { suportes }\end{array}$ & & & & & \\
\hline $\begin{array}{l}\text { Capacidade de } \\
\text { formular } \\
\text { políticas de } \\
\text { pesquisa em } \\
\text { Biblioteconomia } \\
\text { e Ciência da } \\
\text { Informação }\end{array}$ & $\mathrm{C}$ & $C$ & $C$ & $C$ & $C$ \\
\hline $\begin{array}{l}\text { Capacidade de } \\
\text { pesquisa e } \\
\text { domínio das } \\
\text { diversas fontes } \\
\text { de informação }\end{array}$ & 0 & $C$ & 0 & $C$ & 0 \\
\hline $\begin{array}{l}\text { Capacidade de } \\
\text { utilizar recursos } \\
\text { da Tecnologia } \\
\text { da Informação }\end{array}$ & 0 & 0 & 0 & 0 & 0 \\
\hline $\begin{array}{l}\text { Capacidade de } \\
\text { utilizar recursos } \\
\text { de } \\
\text { acessibilidade }\end{array}$ & 0 & 0 & 0 & $C$ & $C$ \\
\hline $\begin{array}{l}\text { Capacidade de } \\
\text { utilizar recursos } \\
\text { de educação à } \\
\text { distância }\end{array}$ & 0 & 0 & 0 & $C$ & $C$ \\
\hline
\end{tabular}

Competências Gerenciais *

\begin{tabular}{|c|c|c|c|c|c|}
\hline & $\begin{array}{l}\text { Sem } \\
\text { relevância }\end{array}$ & $\begin{array}{l}\text { Pouco } \\
\text { relevante }\end{array}$ & $\begin{array}{l}\text { Medianamente } \\
\text { relevante }\end{array}$ & $\begin{array}{l}\text { Muito } \\
\text { relevante }\end{array}$ & $\begin{array}{l}\text { Totalmente } \\
\text { relevante }\end{array}$ \\
\hline $\begin{array}{l}\text { Capacidade } \\
\text { de gerenciar } \\
\text { unidades, } \\
\text { sistemas e } \\
\text { serviços de } \\
\text { informação }\end{array}$ & 0 & 0 & 0 & 0 & 0 \\
\hline $\begin{array}{l}\text { Capacidade } \\
\text { de gerenciar } \\
\text { projetos de } \\
\text { gestão da } \\
\text { informação }\end{array}$ & $C$ & 0 & 0 & 0 & 0 \\
\hline $\begin{array}{l}\text { Capacidade } \\
\text { de aplicar } \\
\text { técnicas de }\end{array}$ & $C$ & 0 & 0 & 0 & 0 \\
\hline
\end{tabular}




\begin{tabular}{|c|c|c|c|c|c|}
\hline & $\begin{array}{l}\text { Sem } \\
\text { relevância }\end{array}$ & $\begin{array}{l}\text { Pouco } \\
\text { relevante }\end{array}$ & $\begin{array}{l}\text { Medianamente } \\
\text { relevante }\end{array}$ & $\begin{array}{l}\text { Muito } \\
\text { relevante }\end{array}$ & $\begin{array}{l}\text { Totalmente } \\
\text { relevante }\end{array}$ \\
\hline $\begin{array}{l}\text { marketing, } \\
\text { de liderança } \\
\text { e de relações } \\
\text { públicas }\end{array}$ & & & & & \\
\hline $\begin{array}{l}\text { Capacidade } \\
\text { de planejar e } \\
\text { gerenciar } \\
\text { recursos } \\
\text { econômicos- } \\
\text { financeiros e } \\
\text { humanos }\end{array}$ & 0 & 0 & $C$ & 0 & 0 \\
\hline $\begin{array}{l}\text { Capacidade } \\
\text { de planejar, } \\
\text { coordenar e } \\
\text { avaliar a } \\
\text { preservação } \\
\text { e } \\
\text { conservação } \\
\text { documental }\end{array}$ & $C$ & 0 & $C$ & $C$ & 0 \\
\hline $\begin{array}{l}\text { Capacidade } \\
\text { de planejar e } \\
\text { desenvolver } \\
\text { estudos de } \\
\text { usuários da } \\
\text { informação }\end{array}$ & 0 & 0 & 0 & 0 & 0 \\
\hline $\begin{array}{l}\text { Capacidade } \\
\text { de gerenciar } \\
\text { redes } \\
\text { colaborativas } \\
\text { de } \\
\text { informação }\end{array}$ & 0 & 0 & 0 & 0 & 0 \\
\hline
\end{tabular}

\section{Competências Sociais e Políticas *}

\begin{tabular}{lllll}
\multicolumn{1}{c}{$\begin{array}{l}\text { Sem } \\
\text { relevância }\end{array}$} & $\begin{array}{l}\text { Pouco } \\
\text { relevante }\end{array}$ & $\begin{array}{l}\text { Medianamente } \\
\text { relevante }\end{array}$ & $\begin{array}{l}\text { Muito } \\
\text { relevante }\end{array}$ & $\begin{array}{l}\text { Totalmente } \\
\text { relevante }\end{array}$ \\
\hline $\begin{array}{l}\text { Capacidade } \\
\text { de formular } \\
\text { políticas de } \\
\text { informação } \\
\text { em } \\
\text { educação }\end{array}$ & & & & \\
\hline $\begin{array}{l}\text { Capacidade } \\
\text { de fomentar } \\
\text { a interação } \\
\text { entre a } \\
\text { biblioteca e }\end{array}$ & 0 & 0 & & \\
\hline
\end{tabular}




\begin{tabular}{|c|c|c|c|c|c|}
\hline & $\begin{array}{l}\text { Sem } \\
\text { relevância }\end{array}$ & $\begin{array}{l}\text { Pouco } \\
\text { relevante }\end{array}$ & $\begin{array}{l}\text { Medianamente } \\
\text { relevante }\end{array}$ & $\begin{array}{l}\text { Muito } \\
\text { relevante }\end{array}$ & $\begin{array}{l}\text { Totalmente } \\
\text { relevante }\end{array}$ \\
\hline $\begin{array}{l}\text { os diversos } \\
\text { tipos de } \\
\text { usuários }\end{array}$ & & & & & \\
\hline $\begin{array}{l}\text { Capacidade } \\
\text { de } \\
\text { identificar } \\
\text { demandas } \\
\text { sociais de } \\
\text { informação }\end{array}$ & $C$ & $C$ & $C$ & $C$ & 0 \\
\hline $\begin{array}{l}\text { Capacidade } \\
\text { de atuar } \\
\text { para } \\
\text { promover a } \\
\text { profissão }\end{array}$ & 0 & $C$ & $C$ & $C$ & 0 \\
\hline $\begin{array}{l}\text { Capacidade } \\
\text { de } \\
\text { promover } \\
\text { ações de } \\
\text { incentivo à } \\
\text { leitura e à } \\
\text { pesquisa } \\
\text { científica }\end{array}$ & 0 & 0 & $C$ & $C$ & $C$ \\
\hline $\begin{array}{l}\text { Capacidade } \\
\text { de } \\
\text { promover a } \\
\text { inclusão } \\
\text { social }\end{array}$ & $C$ & $C$ & $C$ & 0 & $C$ \\
\hline $\begin{array}{l}\text { Capacidade } \\
\text { de formular } \\
\text { políticas de } \\
\text { preservação } \\
\text { do acervo e } \\
\text { da memória } \\
\text { institucional }\end{array}$ & $C$ & $C$ & 0 & $C$ & 0 \\
\hline
\end{tabular}

Utilize o espaço abaixo, caso queira relatar mais alguma competência (além das que foram listadas acima) que você considera relevante, em relação ao trabalho que desempenha em sua Instituição. 


\section{APÊNDICE 2 - ROTEIRO COMPLEMENTAR DA ENTREVISTA}

Prezado Bibliotecário:

No intuito de sanar algumas dúvidas relacionadas as respostas dadas pelos bibliotecários do IFB ao questionário da minha pesquisa de mestrado, farei alguns questionamentos, ainda, sobre o perfil e as competências do bibliotecário que atua no IFB. Suas respostas serão gravadas, mas você não será identificado.

1. Você já teve alguma experiência como bibliotecário, antes de trabalhar no IFB? Em caso afirmativo, indique o(s) local(is) e o(s) períodos.

2. De acordo com o resultado da pesquisa, nenhum bibliotecário do IFB possui, no momento, curso de pós-graduação stricto sensu. Você tem a pretensão de cursar o Mestrado e/ou Doutorado?

Sim. Por que?

Não. Por que?

3. A pesquisa revelou que $35 \%$ dos bibliotecários exercem mais de uma função na biblioteca. Na sua opinião, por que isso ocorre?

4. De acordo com os resultados da pesquisa, nenhum bibliotecário exerce a função de pesquisador. Você não se considera um pesquisador? Justifique.

5. Dentre os fatores que influenciaram o bibliotecário na decisão de seguir carreira no IFB, o item "remuneração" obteve o menor grau de relevância. A que você atribui esse resultado? 